\title{
Lymphotropic Viruses EBV, KSHV and HTLV in Latin America: Epidemiology and Associated Malignancies. A Literature-Based Study by the RIAL-CYTED
}

\author{
Paola Chabay ${ }^{1}$ (D), Daniela Lens ${ }^{2}$, Rocio Hassan ${ }^{3}$, Socorro María Rodríguez Pinilla ${ }^{4}$, \\ Fabiola Valvert Gamboa ${ }^{5}$, Iris Rivera ${ }^{6}$, Fuad Huamán Garaicoa ${ }^{7}$, Stella Maris Ranuncolo ${ }^{8}$, \\ Carlos Barrionuevo ${ }^{9} \mathbb{D}$, Abigail Morales Sánchez ${ }^{10} \mathbb{D}$, Vanesa Scholl ${ }^{11}$, Elena De Matteo ${ }^{1}(\mathbb{D}$, \\ Ma. Victoria Preciado ${ }^{1}$ and Ezequiel M. Fuentes-Pananá 10,*(D)
}

1 Multidisciplinary Institute for Investigation in Pediatric Pathologies (IMIPP), CONICET-GCBA, Molecular Biology Laboratory, Pathology Division, Ricardo Gutiérrez Children's Hospital, C1425EFD Buenos Aires, Argentina; paola_chabay@yahoo.com.ar (P.C.); elenadematteo@gmail.com (E.D.M.); preciado@conicet.gov.ar (M.V.P.)

2 Flow Cytometry and Molecular Biology Laboratory, Departamento Básico de Medicina, Hospital de Clínicas/Facultad de Medicina, Universidad de la República, CP 11600 Montevideo, Uruguay; daniela.lens@gmail.com

3 Oncovirology Laboratory, Bone Marrow Transplantation Center, National Cancer Institute “José Alencar Gomes da Silva" (INCA), Ministry of Health, 20230-130 Rio de Janeiro, Brazil; chassan@inca.gov.br

4 Department of Pathology, University Hospital, Fundación Jiménez Díaz, 28040 Madrid, Spain; smrodriguez@quironsalud.es

5 Department of Medical Oncology, Cancer Institute and National League against Cancer, 01011 Guatemala City, Guatemala; cfvalvert@gmail.com

6 Department of Hematology, Salvadoran Institute of Social Security, Medical Surgical and Oncological Hospital (ISSS), 1101 San Salvador, El Salvador; irisarivera@icloud.com

7 Department of Pathology, National Cancer Institute-Society to Fight Cancer (ION-SOLCA), Santiago de Guayaquil Catholic University, Guayaquil 090615, Ecuador; fuadhuamangaraicoa@gmail.com

8 Cell Biology Department, Institute of Oncology "Angel H. Roffo" School of Medicine, University of Buenos Aires, C1417DTB Buenos Aires, Argentina; smranuncolo@gmail.com

9 Department of Pathology, National Institute of Neoplastic Diseases, National University of San Marcos, 15038 Lima, Peru; carlos.barrionuevo28@gmail.com

10 Research Unit in Virology and Cancer, Children's Hospital of Mexico Federico Gómez, 06720 Mexico City, Mexico; abimor2002@yahoo.com.mx

11 Department of Integrated Genomic Medicine, Conciencia-Oncohematologic Institute of Patagonia, 8300 Neuquén, Argentina; vanesascholl@gmail.com

* Correspondence: empanana@yahoo.com or Ezequiel.Fuentes@alumni.bcm.edu; Tel.: +55-4434-9663 (direct) and +55-5228-9917 (ext. 2129 or 2467)

Received: 11 June 2020; Accepted: 15 July 2020; Published: 4 August 2020

Abstract: The Epstein-Barr virus (EBV), Kaposi sarcoma herpesvirus (KSHV) and human T-lymphotropic virus (HTLV-1) are lymphomagenic viruses with region-specific induced morbidity. The RIAL-CYTED aims to increase the knowledge of lymphoma in Latin America (LA), and, as such, we systematically analyzed the literature to better understand our risk for virus-induced lymphoma. We observed that high endemicity regions for certain lymphomas, e.g., Mexico and Peru, have a high incidence of EBV-positive lymphomas of T/NK cell origin. Peru also carries the highest frequency of EBV-positive classical Hodgkin lymphoma (HL) and EBV-positive diffuse large B cell lymphoma, not otherwise specified (NOS), than any other LA country. Adult T cell lymphoma is endemic to the North of Brazil and Chile. While only few cases of KSHV-positive lymphomas were found, in spite of the close correlation of Kaposi sarcoma and the prevalence of pathogenic types of KSHV. Both EBV-associated HL and Burkitt lymphoma mainly affect young children, unlike in developed countries, in which adolescents and young adults are the most affected, correlating with an early 
EBV seroconversion for LA population despite of lack of infectious mononucleosis symptoms. High endemicity of KSHV and HTLV infection was observed among Amerindian populations, with differences between Amazonian and Andean populations.

Keywords: Epstein-Barr virus; Kaposi sarcoma herpesvirus; human T-lymphotropic virus; lymphoma; Latin America

\section{Introduction}

Neoplasms of an infectious etiology account for about $16 \%$ of all cancers, which amounts to about two million cases per year, considering virus-, bacteria- and parasite-derived cancers. Interestingly, this number is significantly higher for developing countries, in which it can be as high as $30 \%$, while in highly industrialized countries, such as the US, it can be as low as 5\% [1]. The bases for this difference are not clear, but it may be due to the prevalence of the oncogenic infectious agents, or to additional co-factors causally linked to the infectious neoplasms.

Virus-derived cancers almost always originate from established chronic viral infections, because the mechanisms of viral persistence in the infected host are compatible with oncogenesis. Indeed, all human oncogenic viruses express proteins, and/or non-coding RNAs with the capacity to transform cells in culture and induce cancer in transgenic animals [2]. Viral oncogenes tend to enhance cell proliferation and survival, aiming to maintain the pool of infected cells during persistent infections. The International Agency for Research on Cancer (IARC) acknowledges seven viruses as direct human oncogenic agents: the Epstein-Barr virus (EBV), Kaposi sarcoma herpesvirus (KSHV), human T cell lymphotropic virus type 1 (HTLV-1), high risk human papillomaviruses (HPV), hepatitis B virus (HBV), hepatitis C virus (HCV) and Merkel cell polyomavirus (MCPyV) [3]. Although the human immunodeficiency virus (HIV) is also causally associated with several neoplasms, it is as an indirect oncogenic agent, due to the immunosuppression it imposes upon the infected host.

The Epstein-Barr virus (EBV) was the first oncogenic virus discovered 56 years ago by Dr. Anthony Epstein and Dr. Ivonne Barr. EBV was initially observed in samples of Burkitt lymphoma (BL) coming from the equatorial Africa, which represents the perfect example of the unequal geographical distribution of neoplasms of infectious origin. While EBV is responsible for close to $100 \%$ of the BL originating in this region, EBV only accounts for about $20 \%$ of all BLs in developed countries (see below). We later understood that whilst EBV is evenly distributed around the world, the African BL is also associated with repetitive infections with Plasmodium falciparum, an important co-factor of this neoplasm and a parasite endemic to this area. Today, BL is classified within three distinct clinical types, endemic (malaria- and EBV-associated), sporadic (derived from areas in which malaria is not holoendemic) and immunodeficiency-associated [4].

The world distribution of the oncogenic viruses varies significantly, while most adults are already infected with EBV, HPV and MCPyV indistinct of the geographic region, the others tend to be more prevalent in specific populations [2]. Even today, despite the global means of transportation and increased immigration that have allowed a more heterogeneous mix of populations, the prevalence of KSHV and HTLV-1 infection is still restricted to particular geographical areas, implying mechanisms of viral persistence in the population that are not explained by mere socioeconomic factors, but in which genetic susceptibilities, ethnic origin, culture and the prevalence of co-factors may be critical (see below). Like EBV, KSHV and HTLV-1 are associated with lymphoid neoplasms [2]. While EBV mainly infects and persists in B cells, KSHV and HTLV-1 persist in B cells and T cells, respectively, and, as such, they have been associated with $B$ and $T$ cell lymphomas [2].

Latin America (LA) comprises the land from Mexico to Argentina and the Spanish speaking Caribbean, countries with a complex mix of geographies, climates, politics, cultures, ethnicities and different levels of socioeconomic development, and, in which, a high prevalence of oncogenic viruses, 
acute tropical diseases and malnourishment collide. Early epidemiological studies documented a high seroprevalence of KSHV and HTLV-1 in some regions of LA, and to this day, it is common to find in the scientific literature that these viruses are endemic to LA (see below). However, the loco-regional estimation of their prevalence and induced morbidity remains poorly known. The RIAL-CYTED harbors a multidisciplinary Ibero-American network of clinical and basic researchers created to form a platform of multi-center cooperation focusing on increasing our knowledge of lymphoma, particularly for more underdeveloped or developing regions. This network aims to improve the diagnosis and prognosis of these neoplasms throughout LA by way of homogenizing its identification and classification. With that purpose, in this review, we sought to systematically organize and analyze the literature related to the lymphotropic and lymphomagenic viruses EBV, KSHV and HTLV-1, in order to better understand their loco-regional distribution and the risk our population carries in terms of developing lymphoma.

To this end, we explored three web search engines, PubMed, Google Scholar and SciELO, to access all related scientific publications in English, Portuguese and Spanish. Searches were done with the name of each LA country plus the name of each virus individually: Epstein-Barr virus or EBV; KSHV, KSV, HHV8 or Kaposi sarcoma virus; HTLV-1, ATLV or human T-cell lymphoma virus 1. All collected publications were read and classified according to the content; sero-epidemiological studies of KSHV and HTLV-1 viruses were considered, in order to discuss their association with lymphoma in specific regions, while EBV sero-epidemiological studies were discarded, since it is well known that there is a worldwide high prevalence in both developed and developing countries. In case reports and when series of lymphomas were included, we assessed the methods of viral diagnosis, prioritizing those studies in which the presence of the virus was addressed in the lymphoma sample by means of immune or molecular methods. The search was carried out from February 2019 to December 2019, and, although we aimed to include all papers found, regardless of the date of publication, many journals do not have online versions of the documents prior to the 1990s. Moreover, many old studies did not comply with more recent lymphoma classification. The results are disclosed in the next sections for each particular virus.

\section{Epstein-Barr Virus}

EBV is a human gamma-1 herpesvirus usually persisting as a harmless passenger; its growth-transforming ability is linked to a range of lymphoproliferative lesions and malignant lymphomas [5]. EBV-associated lymphomas vary according to the geographic location, age, sex, genetic background and socioeconomic condition [6]. Additionally, the age of primary infection varies substantially worldwide, correlating with socioeconomic factors [7]. In underdeveloped and developing populations, EBV infection is acquired at a young age and is usually asymptomatic. A delay in acquiring primary infection until adolescence or young adulthood, which usually occurs in more developed countries, can manifest as infectious mononucleosis (IM) in 25-75\% of the late infected persons [8].

EBV infection has been associated with the following lymphomas in addition to BL: Hodgkin lymphoma (HL), lymphomas in immunosuppressed individuals (post-transplant lymphoproliferative disorders (PTLD) and HIV-associated lymphoproliferative disorders and T-cell and NK-cell lymphomas) [3]. Furthermore, the last WHO Classification of Tumors of Hematopoietic and Lymphoid Tissues included two new entities specifically associated with EBV: EBV-positive diffuse large B-cell lymphoma (DLBCL) not otherwise specified (NOS) and systemic EBV-positive T-cell lymphoma of childhood [9]. Since the incidence of HIV- and transplant-related lymphoma is more informative of the HIV prevalence or the number of transplanted patients than of the EBV distribution, we will not cover them in this review. See Table 1 for the studies considered and the frequency of EBV association. 
Table 1. Summary of studies about Epstein-Barr virus (EBV) associated lymphomas.

\begin{tabular}{|c|c|c|c|c|c|}
\hline Country (Ref) & Lymphoma Type & Type of Study & Methods & EBV Association & Description of the Study \\
\hline Argentina [10-12] & DLBCL (ad/ped) & Cohort & ISH, IHC & $12.6 \%(12 / 95)$ & $\begin{array}{l}26 \text { DLBCL ped; } 69 \text { DLBCL ad from Buenos Aires, Argentina. } \\
\text { EBV prevalence } 72 \% \text { ped. }\end{array}$ \\
\hline Argentina [13] & PBL & Case report & ISH & $100 \%$ & 1 PBL in HIV+ patient from Buenos Aires, Argentina. \\
\hline Argentina [14] & BL (ped) & Cohort & ISH, IHC & $\begin{array}{l}29 \% \text { IHC (7/24); } \\
100 \% \text { ISH }(3 / 3)\end{array}$ & 27 pediatric BL, 3 HIV+ from Buenos Aires, Argentina. \\
\hline Argentina [15] & PBL & 4 cases & ISH, IHC & $100 \%(4 / 4)$ & 4 PBL in HIV+ patients from Buenos Aires, Argentina. \\
\hline Argentina [16] & B-NHL (ped) & Cohort & ISH & $\begin{array}{l}40 \%(16 / 40)(35 \% \text { BL; } \\
\quad 47 \% \text { DLBCL) }\end{array}$ & 23 BL ped, 17 DLBCL ped from Buenos Aires, Argentina. \\
\hline Argentina [17] & PBL & Case report & ISH & $100 \%$ & 1 PBL in HIV+ from Buenos Aires, Argentina. \\
\hline Argentina [18] & PBL & Case report & ISH & $100 \%$ & 1 PBL in HIV+ from Buenos Aires, Argentina. \\
\hline Argentina [19] & T-NHL (ped) & Cohort & ISH, IHC & $8 \%(2 / 25)$ & $\begin{array}{l}16 \text { lymphoblastic, } 8 \text { anaplastic, } 1 \text { hepatoesplenic T-cell } \\
\text { lymphoma ped from Buenos Aires, Argentina. }\end{array}$ \\
\hline Argentina/Brazil [20] & HL (ped) & Cohort & ISH, IHC & $\begin{array}{l}54 \%(\mathrm{Arg} ; 60 / 111) \\
48 \%(\mathrm{Bra} ; 31 / 65)\end{array}$ & $\begin{array}{l}111 \mathrm{HL} \text { ped from Buenos Aires, Argentina. } 65 \mathrm{HL} \text { ped from Rio } \\
\text { de Janeiro, Brazil. }\end{array}$ \\
\hline Argentina [21] & PCNSL & 7 cases & ISH, PCR & $100 \%(6 / 6)$ & 7 PCNSL cases HIV+ from Buenos Aires, Argentina. \\
\hline Argentina [22] & HL (ad, ped) & Cohort & ISH & $\begin{array}{l}55 \% \text { ped }(51 / 92) \\
31 \% \text { ad }(25 / 81)\end{array}$ & $92 \mathrm{HL}$ ped, $81 \mathrm{HL}$ ad from Buenos Aires, Argentina. \\
\hline Argentina [23] & HIV+ HL, BL, DLBCL & 4 cases & ISH, IHC & $100 \%(4 / 4)$ & $1 \mathrm{HL}, 2$ BL, 1 DLBCL ped HIV+ from Buenos Aires, Argentina. \\
\hline Argentina [24] & BL (ped) & Cohort & ISH, PCR & $47 \%(8 / 17)$ & 17 BL ped from Buenos Aires, Argentina. \\
\hline Argentina [25-27] & HL (ped) & Cohort & ISH & $51 \%(22 / 41)$ & $41 \mathrm{HL}$ ped from Buenos Aires, Argentina. \\
\hline Argentina [28] & BL (ped) & Cohort & ISH & $25 \%(4 / 16)$ & 16 BL ped from La Plata, Argentina. \\
\hline Brazil [29] & DLBCL & Cohort & ISH & $30 \%(28 / 93)$ & 93 DLBCL ad from Sao Paulo, Brazil. \\
\hline Brazil [30] & NT/NKL & Case report & $\mathrm{IHC}$ & $100 \%$ & 1 NK/NKL from Rio Janeiro, Brazil. \\
\hline Brazil [31] & HVL-LD & Case report & ISH & $100 \%$ & 1 HVL- LD from Dom Eliseu City, Pará, Brazil. \\
\hline Brazil [32] & $\begin{array}{l}\text { HL (ad/ped, } \\
\text { temporal series) }\end{array}$ & Cohort & ISH & $87-46 \%(817)$ & 155 HL ped, 662 HL ad from Sao Paulo, Brazil. \\
\hline Brazil [33] & $\begin{array}{l}\text { Intermediate BL with } \\
\text { DLBCL }\end{array}$ & Case report & ISH & $100 \%$ & 1 int BL DLBCL from Recife, Brazil. \\
\hline Brazil [34] & DLBCL (>50 yo) & Cohort & ISH & $8.45 \%(6 / 71)$ & 71 DLBCL ad from Sao Paulo, Brazil. \\
\hline Brazil [35] & $\mathrm{T} / \mathrm{NKL}$ & Case report & ISH & $100 \%$ & T/NKL HIV+ from Sao Paulo, Brazil. \\
\hline Brazil [36] & BL (ped) & Cohort & ISH & $100 \%(7 / 7)$ & 4 BL ped, 3 BL ad from Amazonas, Brazil. \\
\hline
\end{tabular}


Table 1. Cont.

\begin{tabular}{|c|c|c|c|c|c|}
\hline Country (Ref) & Lymphoma Type & Type of Study & Methods & EBV Association & Description of the Study \\
\hline Brazil [37] & BL (ped) & Cohort & ISH & $54.1 \%(33 / 61)$ & 61 BL ped from Rio de Janeiro, Brazil. \\
\hline Brazil [38] & HL (ad, ped) & Cohort & ISH & $43 \%(56 / 130)$ & 130 HL from Sao Paulo, Brazil. \\
\hline Brazil [39] & HVL-LD & Case report & ISH & $100 \%$ & 1 HVL-LD from Manaus Amazonas, Brazil. \\
\hline Brazil [40] & DLBCL, Palatine tonsil & Cohort & ISH & $0 \%(0 / 26)$ & 26 DLBCL from Bahia, Brazil. \\
\hline Brazil [41-43] & HL (ped) & Cohort & ISH & $44.8 \%(43 / 96)$ & 96 HL ped from Rio de Janeiro, Brazil. \\
\hline Brazil $[44,45]$ & $\mathrm{HL}(\mathrm{ad})$ & Cohort & ISH & $52.6 \%(51 / 97)$ & 97 HL ad from Sao Paulo, Brazil. \\
\hline Brazil [46] & ENKTCL (ad, ped) & Cohort & ISH, PCR & $100 \%(74 / 74)$ & 74 ENKTCL from Sao Paulo, Brazil. \\
\hline Brazil [47] & $\mathrm{HL}(\mathrm{ad})$ & Cohort & ISH & $22 \%(5 / 23)$ & 23 HL ad from Sao Paulo, Brazil. \\
\hline Brazil [48] & CNS DLBCL (ad) & Cohort & ISH & $\begin{array}{l}5.5 \% \text { total }(2 / 36) \\
(40 \% \text { IS })\end{array}$ & 36 CNS DLBCL from Sao Paulo, Brazil. \\
\hline Brazil [49] & HL (stomach) & 5 cases & ISH & $80 \%(4 / 5)$ & 5 HL from Sao Paulo, Brazil. \\
\hline Brazil [50] & B-NHL (ped) & Cohort & ISH, qPCR & $23 \%(7 / 30)$ & 30 NHL ped from Rio de Janeiro and Sao Paulo, Brazil. \\
\hline Brazil [51] & $\mathrm{HL}+\mathrm{PTL}$ & Case report & ISH & $100 \%$ & HL PTL from Sao Paulo, Brazil. \\
\hline Brazil [52] & HL (ad, ped) & Cohort & ISH, IHC & $50.3 \%(85 / 169)$ & 169 HL from Sao Paulo, Brazil. \\
\hline Brazil $[53,54]$ & BL (ad, ped) & Cohort & ISH & $52.6 \%(123 / 234)$ & $\begin{array}{l}\text { North Region }(n=17 \text { cases }), \text { Central West Region }(n=17 \text { cases }) \text {, } \\
\text { Northeast Region( }(n=86 \text { cases), Southeast Region }(n=72 \text { cases } \\
\text { South Region }(n=42 \text { cases })\end{array}$ \\
\hline Brazil [55] & BL (ped) & Cohort & ISH & $66 \%(33 / 50)$ & 143 pediatricos y 88 adultos, 3 sin edad). \\
\hline Brazil [56] & BL (ped) & Cohort & ISH & $61 \%(33 / 54)$ & San pablo \\
\hline Brazil [57] & PBL & 11 cases & ISH, PCR & $100 \%(11 / 11)$ & Rio de janeiro \\
\hline Brazil [58] & HL (ad, ped) & Cohort & ISH, IHC & $48 \%(22 / 46)$ & San pablo \\
\hline Brazil [59] & PCNSL & 10 cases & $\mathrm{IHC}$ & $10 \%(1 / 10)$ & Florianopolis, South of Brazil \\
\hline Brazil [60] & $\mathrm{HL}(\mathrm{ad})$ & Cohort & IHC, PCR & $\begin{array}{c}37 \%(11 / 30) ; \\
43 \% \text { Circulating EBV }\end{array}$ & 14 patients $<15$ years y $32>15$ years \\
\hline Brazil [61] & HL (ped) & Cohort & ISH & $86.7 \%(78 / 90)$ & Niterói RJ \\
\hline Brazil [62-64] & B-NHL (ped) & Cohort & ISH, PCR & $72 \%(21 / 29)$ & 29 NHL from Rio de Janeiro, Brazil. \\
\hline Brazil [65] & HL (ad) & Cohort & ISH, IHC & $75.6 \%(28 / 37)$ & 37 HL ad from Ceara, Brazil. \\
\hline Brazil [66] & $\mathrm{HL}(\mathrm{ad})$ & Cohort & $\mathrm{IHC}$ & $45.8 \%(38 / 83)$ & $83 \mathrm{HL}$ ad from Rio de Janeiro, Brazil. \\
\hline Brazil [67] & HL (ad, ped) & Cohort & IHC & $55 \%(35 / 64)$ & $64 \mathrm{HL}$ ad from Rio de Janeiro, Brazil. \\
\hline
\end{tabular}


Table 1. Cont

\begin{tabular}{|c|c|c|c|c|c|}
\hline Country (Ref) & Lymphoma Type & Type of Study & Methods & EBV Association & Description of the Study \\
\hline Brazil $[68,69]$ & $\mathrm{HL}(\mathrm{ad})$ & Cohort & ISH, IHC & $64.1 \%(50 / 78)$ & $78 \mathrm{HL}$ ad from Rio de Janeiro, Brazil. \\
\hline Brazil [70] & HL (ad, ped) & Cohort & ISH & $63.5 \%(61 / 96)$ & 96 HL from Sao Paulo and Ceara, Brazil. \\
\hline Brazil [71] & ENKTCL & Cohort & ISH & $100 \%(16 / 16)$ & 16 ENKTCL from Sao Paulo, Brazil. \\
\hline Brazil [72] & BL (ped) & Cohort & ISH & $73 \%(8 / 11)$ & 11 BL ped from Recife, Brazil. \\
\hline Brazil [73] & HL (ped) & Cohort & ISH & $57.7 \%(15 / 26)$ & 26 HL ped from Curitiba, Brazil. \\
\hline Brazil [74] & BL (ped) & Cohort & ISH & $87 \%(47 / 54)$ & 54 BL ped from Bahia, Brazil. \\
\hline Brazil [75] & BL & Cohort & ISH & $71 \%(17 / 24)$ & 24 BL from Sao Paulo, Brazil. \\
\hline Brazil [76] & HL (ped) & Cohort & ISH & $72 \%(18 / 25)$ & $25 \mathrm{HL}$ ped from Sao Paulo, Brazil. \\
\hline Mexico [77] & HVL-LD & Cohort & ISH & $100 \%(20 / 20)$ & 20 HVL-LD ped from Mexico City, Mexico. \\
\hline Mexico [78] & HL (ad, ped) & Cohort & ISH & $\begin{array}{c}76.1 \% \text { ped }(22 / 42) \\
66.6 \% \text { ad }(16 / 24)\end{array}$ & $42 \mathrm{HL}$ ped, $24 \mathrm{HL}$ ad from Mexico City, Mexico. \\
\hline Mexico [79] & PCL & Case report & ISH & $100 \%$ & 1 PCL from Mexico City, Mexico. \\
\hline Mexico [80] & PBL & 5 cases & PCR & $80 \%(4 / 5)$ & 5 PBL ad HIV+ from Mexico City, Mexico. \\
\hline Mexico [81] & DLBCL (>50 yrs) & Cohort & ISH & $7 \%(9 / 136)$ & 136 DLBCL ad from Mexico City, Mexico. \\
\hline Mexico [82] & HL (mostly ad) & Cohort & ISH, IHC & $61.4 \%(35 / 57)$ & $54 \mathrm{HL}$ ad, $3 \mathrm{HL}$ ped from Mexico City, Mexico. \\
\hline Mexico [83] & ENKTCL & Cohort & ISH & $96 \%(22 / 23)$ & 23 ENKTCL from Mexico City, Mexico. \\
\hline Mexico/Bolivia [84] & HVL-LD /ACTCLC & 4 cases & ISH & $75 \%(3 / 4)$ & 4 ACTCLC ped from Mexico City and La Paz \\
\hline Mexico [85] & PTLD & 8 cases & ISH & $100 \%(8 / 8)$ & 8 PTLD ad from Mexico City, Mexico. \\
\hline Mexico [86] & NHL, Intestinal & Cohort & ISH & $63 \%(12 / 19)$ & $7 \mathrm{~T}, 6$ high grade B, 6 low grade B-NHLs from Mexico City, Mexico \\
\hline Mexico $[87,88]$ & $\mathrm{HL}(\mathrm{ad})$ & Cohort & $\mathrm{IHC}$ & $70 \%(35 / 50)$ & 50 HL ad from Mexico City, Mexico. \\
\hline Mexico [89] & HL (ad, ped) & Cohort & ISH, IHC & $67 \%(18 / 27)$ & 3 HL ped, 24 HL ad from Mexico City, Mexico. \\
\hline PR [90] & HL \& NHL (ad, ped) & Cohort & $\mathrm{IHC}$ & $\begin{array}{c}50 \% \text { HL (11/22); } \\
35 \% \text { NHL (22/63) }\end{array}$ & 22 HL, 63 NHL from San Juan de Puerto Rico, Puerto Rico. \\
\hline DR [91] & HL (ped) & Cohort & $\mathrm{IHC}$ & $64.3 \%(18 / 28)$ & 28 HL ped from Santiago, Dominican Republic \\
\hline Cuba [92] & BL (ped) & 7 cases & EBV Serology & $85.7 \%(6 / 7)$ & EBV prevalence in 7 BL ped from La Habana, Cuba. \\
\hline Colombia $[93,94]$ & HL (ad, ped) & Cohort & ISH, IHC & $\begin{array}{l}67 \%(45 / 67) 60.4 \% \\
\text { ad; } 84.2 \% \text { ped }\end{array}$ & $48 \mathrm{HL}$ ad, $19 \mathrm{HL}$ ped from Bogotá, Colombia \\
\hline Peru [95] & DLBCL (ad) & Cohort & ISH & $28 \%(33 / 117)$ & 117 DLBCL ad from Lima and Arequipa, Peru. \\
\hline
\end{tabular}


Table 1. Cont.

\begin{tabular}{|c|c|c|c|c|c|}
\hline Country (Ref) & Lymphoma Type & Type of Study & Methods & EBV Association & Description of the Study \\
\hline Peru [96] & $\begin{array}{l}\text { LBCL in cardiac } \\
\text { myxoma (ad) }\end{array}$ & Case report & ISH & $100 \%$ & LBCL ad from Lima, Peru. \\
\hline Peru [97] & HVL-LD & 4 cases & ISH & $100 \%(3 / 3)$ & 4 HVL-LD ped from Lima, Peru. \\
\hline Peru [98] & EBV+ DLBCL GI (ad) & 5 cases & ISH & $100 \%(5 / 5)$ & 5 DLBCL GI ad from Lima, Peru. \\
\hline Peru [99] & Systemic T/NKL & 6 cases & ISH, IHC & $100 \%(6 / 6)$ & 6 T/NKL ped from Lima, Peru. \\
\hline Peru $[100,101]$ & EBV+ DLBCL (>50 yo) & Cohort & ISH & $14 \%(28 / 199)$ & 199 DLBCL ad from Lima, Peru. \\
\hline Peru [102] & DLCBL in a HTLV-1+ & Case report & ISH & $100 \%$ & DLBCL ad from Lima, Peru. \\
\hline Peru [103] & $\begin{array}{l}\text { Cutaneous T/NKL } \\
\text { (11/15 HVL-LD) }\end{array}$ & Cohort & ISH & $100 \%(15 / 15)$ & 12 T/NKL ped, 2 T/NKL ad from Lima, Peru. \\
\hline Peru [104] & ENKTCL & Cohort & PCR & $99 \%(76 / 77)$ & 77 ENKTCL from Lima, Peru. \\
\hline Peru [105] & HVL-LD & 6 cases & ISH & $100 \%(6 / 6)$ & 6 HVL-LD ped from Lima, Peru. \\
\hline Peru [106] & ENKTCL & Cohort & ISH, IHC & $96 \%(27 / 28)$ & 28 ENKTCL ad from Lima, Peru. \\
\hline Peru [107] & Nasal lymphoma & Cohort & ISH & $\begin{array}{l}93 \%(14 / 13 ; \\
11 / 11 \text { T-cell })\end{array}$ & 13 Nasal lymphoma from Lima, Peru. \\
\hline Peru [108] & HL (mostly ped) & Cohort & ISH, IHC & $94 \%(30 / 32)$ & 32 HL from Lima, Peru. \\
\hline Ecuador [109] & HVL-LD & 2 cases & ISH & $100 \%$ & 1 HVL-LD ped, 1 HVL-LD ad from Quito, Ecuador. \\
\hline Ecuador [110] & HL and NHL (ad) & Cohort & ISH, qPCR & $\begin{array}{c}55.5 \% \text { HL (5/9); } \\
59.5 \% \text { NHL (25/42) }\end{array}$ & $9 \mathrm{HL}$ ad, $42 \mathrm{NHL}$ ad from Guayaquil, Ecuador. \\
\hline Chile [111] & $\mathrm{EBV}+\mathrm{DLBCL}$ & Case report & ISH & $\begin{array}{c}100 \% \\
\text { (Leukocytoclastic } \\
\text { vasculitis) }\end{array}$ & DLBCL from Santiago, Chile. \\
\hline Chile [112] & Nasal lymphoma & Cohort & ISH & $\begin{array}{c}\text { DLCBL 0\% (0/3); } \\
\text { T-cell 0\% }(0 / 1) ; \\
\text { NKT 100\% (6/6) }\end{array}$ & 3 DLBCL, 1 T-cell lymphoma, 6 NKT from Valdivia, Chile. \\
\hline Chile [113] & ENKTCL & Cohort & ISH & $78 \%(7 / 9)$ & 9 ENKTCL ad from Santiago, Chile. \\
\hline $\begin{array}{l}\text { Chile /Argentina } \\
\text { /Brazil [114] }\end{array}$ & BL (mostly ped) & Cohort & ISH & $\begin{array}{c}41 \% \text { (7/17 Arg); } \\
50 \% \text { (5/10 Chile); } \\
58 \% \text { (7/12 Br) }\end{array}$ & $\begin{array}{l}37 \text { BL ped, } 2 \text { BL ad from Buenos Aires, Argentina; Santiago, } \\
\text { Chile; Campinas, Brazil. }\end{array}$ \\
\hline Honduras [115] & HL (ped) & Cohort & ISH & $100 \%(11 / 11)$ & 11 HL ped from Tegucigalpa, Honduras. \\
\hline CR [116] & HL (ad, ped) & Cohort & $\mathrm{IHC}$ & $40 \%(16 / 40)$ & 6 HL ped, 34 HL ad from San Jose, Costa Rica. \\
\hline CR [117] & HL (ped) & Cohort & ISH, IHC & $81 \%(34 / 42)$ & 42 HL from San José, Costa Rica. \\
\hline
\end{tabular}


Table 1. Cont.

\begin{tabular}{cccccc}
\hline Country (Ref) & Lymphoma Type & Type of Study & Methods & EBV Association & Description of the Study \\
\hline CR/Mexico [118] & HL (ad, >15 yo) & Cohort & ISH, SB & $\begin{array}{c}36 \%(5 / 14) \text { CR; } \\
77 \%(24 / 31) \text { Mexico }\end{array}$ & 45 HL ad from Mexico City, Mexico; San Jose, Costa Rica. \\
\hline Bolivia [119] & NHL & 8 cases & ISH & $75 \%(6 / 8)$ & 8 NHL from Santa Cruz, Bolivia. \\
\hline Guatemala [120] & ENKTCL & Cohort & ISH & $87 \%(73 / 84)$ & 59 ENKTCL from Guatemala City, Guatemala. \\
\hline
\end{tabular}

ACTCLC: angiocentric cutaneous T-cell lymphomas of childhood; B-NHL: B-cell non-Hodgkin lymphoma; CNS: central nervous system; CSF: cerebrospinal fluid; DLBCL: diffuse large B cell lymphoma; GI, gastrointestinal; HL, Hodgkin lymphoma; HVL-LD: hydroa vacciniform-like lymphoproliferative disease; IC: immunocompetent; IHC: immunohistochemistry; cell lymphoma; GI, gastrointestinal; HL, Hodgkin lymphoma; HVL-LD: hydroa vacciniform-like lymphoproliferative disease; IC: immunocompetent; IHC: immunohistochemistry; IS: immunosuppressed; ISH: Epstein-Barr virus-encoded small RNAs (EBERs) in situ hybridization; ENKTCL: extranodal nasal-type T-cell/NK lymphoma, PBL: plasmablastic lymphoma,
PCL: plasma cell myeloma; PCNSL: primary central nervous system lymphoma; PTL: peripheral T cell lymphoma; qPCR: quantitative real-time PCR; SB: Southern blot; T-NHL: T-cell PCL: plasma cell myeloma; PCNSL: primary central nervous system lymphoma; PTL: peripheral T cell lymphoma; qPCR: quantitative real-time PCR; SB: Southern blot; T-NHL: T-cell
Non-Hodgkin Lymphoma; Pt: patient; ad: adult; ped: pediatric. Countries PR, DR and CR: Puerto Rico, Dominican Republic and Costa Rica. virus+ refers to virus positive samples. 


\subsection{EBV-Associated Lymphoid Neoplasms in Latin America}

\subsubsection{Hodgkin Lymphoma}

There are several series of lymphomas reported in this region, particularly at the end of last century, which, however, were only classified as Hodgkin and non-Hodgkin (NHL), and which obviously did not follow the latest WHO classification. HL has a bimodal age distribution, there is an early peak occurring in adolescents and young adults, and a late peak after 50 years of age in industrialized countries. Developing countries also exhibit a bimodal distribution of the disease, but the early peak starts before adolescence [121]. In the US, pediatric HL shows the highest incidence in adolescents between 15-19 years of age, while developing countries present similar incidences than the US for adolescents, but also exhibit a marked augmented incidence in young children [122,123]. In developing countries, classical HL (cHL) with an early onset (14 yrs or younger) shows high EBV association, more often of the mixed cellularity (HL-MC) subtype. A strong male to female predominance is also observed, particularly in the group younger than $5 \mathrm{yrs}$, in which the ratio is 5:1. HL in adolescents and young adults displays lower EBV association, nodular sclerosis subtype (HL-NS) predominance and affects male and females almost equally [122].

We found 36 studies of HL in LA, including pediatric and adult series from 12 countries. Pediatric series from Argentina exhibited a profile compatible with early cHL (i.e., younger ages, EBV positivity of $\sim 50 \%$ and HL-MC as the predominant subtype) [20,25-27], while adult HL displayed a $31 \%$ of EBV-association, with similar frequencies of both NS and MC subtypes [22]. On the other hand, in the Southeast of Brazil, EBV positivity was $40-50 \%$, HL-NS was the predominant subtype, and there was a smooth peak between adolescents and young adults $[38,41-45,47,52,58,60,66-70,73]$, which may suggest a transition state in the epidemiology of the disease presentation between the ones observed in developing and developed areas. Indeed, one study in the most affluent Brazilian State (Sao Paulo) reviewed 817 cases of cHL over 54 years (1954-2008), describing that EBV-positive cases showed a decrease from $87 \%$ to $46 \%$ during the time of the study, with a remarkable decrease in young adults ( $85 \%$ to $32 \%$ ) [32]. Nevertheless, HL-NS was still the predominant subtype in all periods. On the contrary, HL in the North of Brazil exhibits high EBV association (87\%), HL-MC and young age predominance [61]. These results support the hypothesis that the socioeconomic level may determine the presentation features of this neoplasm, also highlighting the role of EBV as an HL driver that is also influenced by socioeconomic factors. Figure 1A-D shows examples of EBV positive HL-NS and HL-MC.

There is only one large pediatric cohort of 42 cases published from Mexico, with a median age of 5 yrs at diagnosis, and in which a male predominance (2.5:1) was observed [78]. EBV positivity was found in $76.1 \%$ of the cases and the HL-MC subtype was the most predominant $(71.4 \%)$. Other studies from Mexico mostly include young and older adults, with scarce inclusion of children and adolescents, and in which EBV association frequencies vary between $61 \%$ and $77 \%$. In those studies, a predominance of HL-MC and HL-NS subtypes was observed [82,87-89,118]. In these Mexican studies, a high EBV association was also observed for the lymphocyte depleted (HL-LD) subtype, with $91.2 \%$ positive cases [87-89].

In line with the above-described data, a $94 \%$ of EBV association was observed in pediatric HL in Peru [108], while in Colombia, EBV association varied from $60 \%$ in adults to $84 \%$ in children $[93,94]$. Another study from Honduras that included 11 children younger than 15 yo also found $100 \%$ EBV positivity [115]. Series of studies from the Caribbean and continental Central American countries: Puerto Rico, Ecuador, Costa Rica and the Dominican Republic found intermediate EBV association frequencies (50\%, 55\%, 36-40\% and $64 \%$, respectively) $[90,91,110,116-118]$, which are closer to the frequencies observed in the more developed Argentina. These frequencies should be confirmed with more samples and up-to-date techniques. 


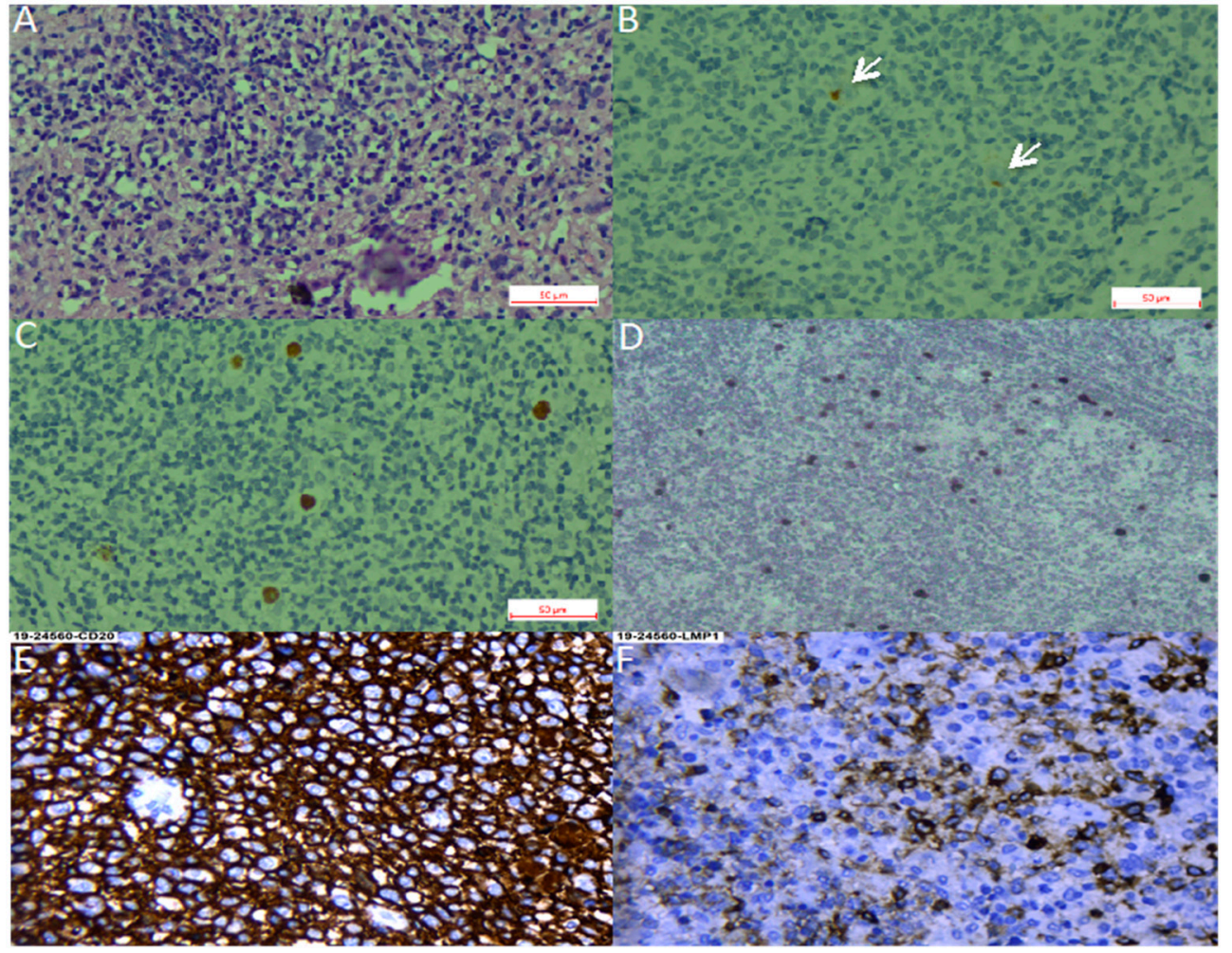

Figure 1. Hodgkin lymphoma. (A-C). Nodular sclerosis Hodgkin lymphoma. (A). Hematoxylin-Eosin staining. (B). CD30 staining with arrows pointing at positive Reed-Sternberg cells. (C). Epstein-Barr virus-encoded small RNAs (EBER) in situ hybridization. (D). EBER in situ hybridization of a mixed cellularity Hodgkin lymphoma, magnification 40×. (E,F). Diffuse large B cell lymphoma, magnification 40×. (E). CD30 staining. (F). LMP1 (latent membrane protein 1) staining.

\subsubsection{Burkitt Lymphoma}

BL is a highly aggressive B cell lymphoma, characterized by the translocation of the MYC oncogene to the immunoglobulin loci. It affects mostly children and is also more predominant in males [124]. EBV-associated BL conforms almost $100 \%$ of endemic BL and around $20 \%$ of sporadic cases of North America and Europe. Other regions of the world, especially developing populations, exhibit intermediate frequencies, such as 50-70\% in North Africa and Russia [3,125]. Pediatric BL in Argentina has an EBV association frequency closer to the sporadic subtype (25-47\%), and the highest incidence of EBV-positive cases is in children younger than 5 yo $[14,16,24,28]$. As with $\mathrm{HL}$, the frequency of EBV positive cases increase with latitude in Brazil, being 60\% in the South East $[37,55,56,62-64]$, and $73-87 \%$ in North East [72,74]. A study including an extensive number of BL cases from five Brazilian geographic regions confirmed this trend, disclosing EBV association frequencies from $29 \%$ in the South to $76 \%$ in the North $[53,54]$. This pattern appears to represent a socio-geographic gradient, which might reflect social development, as well as other unknown environmental, ethnic or genetic factors [63]. A Brazilian study of 14 population-based cancer registries showed that the global age-adjusted incidence rate for pediatric BL does not differ significantly from the expected for a sporadic BL region. However, the incidence was elevated for BL children aged 1-4 years [126]. Given the association of EBV positive BL with young age, it is tempting to ascribe this elevated risk to the early EBV seroconversion, which is characteristic of the natural history of EBV infection in our geographic region [127]. Indeed, an EBV-associated BL inverse correlation with age has been shown in other studies from Brazil [56] and Argentina [14]. Unfortunately, we could not find reports on BL series from the Andean and Caribbean regions of LA, which, most probably, does not represent a low frequency of this lymphoma there. Although there are 
studies including BL from Mexico, they do not address EBV infection, and there is only one case report from a 63 yo male with an EBV positive intraoral BL [128].

\subsubsection{Diffuse Large B Cell Lymphoma}

DLBCL is a highly aggressive neoplasm that can arise in almost any location of the body. It is very rare in pediatric patients and young adults, but is one of the most common NHLs in older individuals. Due to the median age of presentation of $70 \mathrm{yrs}$, it is usually associated with underlying immunosuppression. In the former 2008 WHO classification [129], EBV-positive DLBCL of the elderly ( $>50$ years) was recognized as a provisional entity among the DLBCL subtypes. This provisional entity represented $5-11 \%$ of the DLBCL among immunocompetent East Asian patients [130], while in Western populations, the frequency was lower than $5 \%$ [81,131]. The reported series from LA have shown slightly higher EBV association frequencies (7\% México, 9\% Brazil, 13\% Argentina and 14-28\% Peru) $[10-12,34,81,95,100,101]$ than the observed in Western countries [81]. LA patients are also younger than the ones described in other series $[11,81]$. Peru is particularly interesting, since it has the highest incidence of positive EBV DLBCLs, in addition to the incidence of DLBCL being the highest reported, accounting for up to $45 \%$ of all lymphomas $[100,101,132]$. In a Peruvian study of five cases, DLBCL of the gastrointestinal tract was consistently associated with EBV infection in elderly patients [98]. Remarkably, a series of cases of DLBCL of the palatine tonsils from Salvador de Bahia Brazil did not find an association with EBV [40]. Figure 1E,F shows an example of an EBV positive DLBCL.

In the 2016 WHO classification of lymphoid neoplasms, the age factor was eliminated from the association of EBV with DLBCL, leading to the substitution of the modifier "elderly" with "not otherwise specified" (EBV-positive DLBCL, NOS) [9]. Therefore, new studies free from the restraint of the age limit are needed, to better characterize the magnitude of this association, as well as the prognostic impact of EBV positivity in LA patients. DLBCL are also distinguished by their phenotype as germinal center or activated, with the former exhibiting an overall better survival rate. No differences were found in a series of Argentinian cases with respect to EBV positivity in these two subtypes of DLBCL $[11,95]$.

\subsubsection{T and NK Lymphoproliferative Disorders}

Although EBV tropism is mainly of B cells and in healthy individuals exclusively localizes in B cells [133], the revised 2016 WHO classification recognizes the chronic active EBV infection (CAEBV) of T/NK cell type, the aggressive NK-cell leukemia, the systemic T-cell lymphoma of childhood and the extranodal NK/T-cell lymphoma, nasal type (ENKTCL), as well as a new provisional entity, the primary EBV-positive nodal T/NK-cell lymphoma [9,134]. These neoplasms represent a broad spectrum of diseases that occur with higher incidence in Asian populations, and, in which, CAEBV, the aggressive NK leukemia and the systemic T-cell lymphoma are more prevalent in children and adolescents, while ENKTCL mainly affects adults $[9,134]$. How the virus infects T or NK cells is still a matter of debate, but exists some evidence of a preferential tropism for T cells for the EBV-2 subtype $[135,136]$.

CAEBV corresponds to a group of reactive LPDs associated with a heightened EBV infection lasting longer than IM, and with the potential to progress to a systemic lymphoma. The clinical picture is diverse and includes the indolent, localized cutaneous form hydroa vacciniform-like LPD (HVL-LPD), renamed by the revised 2016 WHO classification [9]. Several series of patients with HVL-LPD have been described in LA indicating a high incidence of this disease, mainly in countries with a large Amerindian population component, such as Mexico [77,84], Bolivia [84], Peru [97,103,105] and Ecuador [109]. In Brazil, two HVL-LPD cases were reported in children from Amazon indigenous tribes, supporting the ethnic bias of this disease [31,39]. In these series of patients, the association with EBV was virtually $100 \%$. These studies have also greatly contributed to illustrate the clinical and pathological features of this disease in LA as an LPD with $70 \%$ of cases being of T-cell origin and $30 \%$ of NK origin. This scenario is more similar to Asian CAEBV, since, in the US, CAEBV is very rare, and also presents as a B cell LPD [137]. Although cellular and viral monoclonality has been proven in the majority 
of T-cell cases, the disease is today considered an LPD, with a high risk to progress into a systemic lymphoma [77], to reflect the diverse clinical spectrum of the disease presentation, from self-limited $\mathrm{HV}$ to HV-like lymphoma, and also to allow for more adequate therapeutic approaches, since patients respond well to immunomodulatory agents as first line of treatment $[77,103,105]$.

Extranodal NK/T cell lymphoma (ENKTCL) is an EBV-positive lymphoma more commonly derived from NK cells. Similar to CAEBV lymphoproliferations, this type of lymphoma has been described mainly in East Asia and LA, in which the ethnic composition includes a high proportion of Amerindians. EBV infection is also confirmed in virtually all cases. Series of cases have been reported from México [83], Peru [104,106], Chile [104,106,112,113] and Guatemala [120]. In Brazil, ENKTCL usually occurs as isolated cases [71]. Recently, a large series was reported that included 122 cases with mostly adults (only three children) from all five Brazilian regions [46]. In this Brazilian cohort, the clinico-pathological characteristics of the neoplasm were similar to the ones described in patients from East Asia and other American countries, in which the disease is considered endemic. No ethnic data was recorded for the patients included in the study. In a Brazilian unicentric study that included lymphomas involving the midline facial region, 16 were of $\mathrm{T} / \mathrm{NK}$ cell origin and nine were of $\mathrm{B}$ cell origin $(n=25)$. Remarkably, no ethnic differences were found between the patients with $\mathrm{T} / \mathrm{NK}$ or $\mathrm{B}$ cell presentation [71]. Figure 2 shows an example of an ENKTCL.

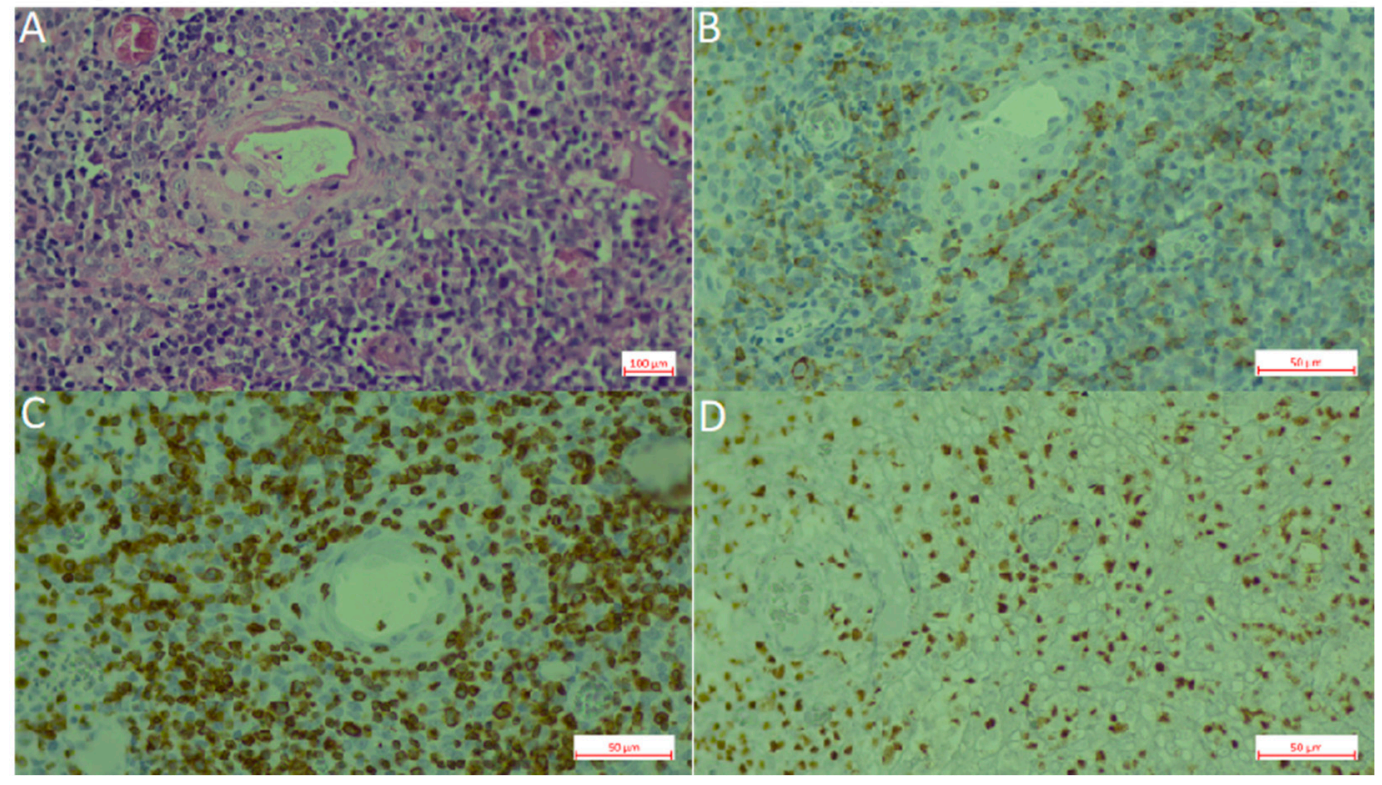

Figure 2. Extranodal natural killer (NK)/T-cell lymphoma, nasal type (ENKL). (A). Hematoxylin-Eosin staining. (B). CD56 staining. (C). CD3 staining. (D). EBER in situ hybridization.

\section{Kaposi Sarcoma Human Herpesvirus}

KSHV is a gamma-2 herpesvirus closely related to EBV, also called human herpesvirus 8 or HHV8. KSHV is the etiological agent of Kaposi sarcoma (KS), multicentric Castleman disease (MCD) and primary effusion lymphoma (PEL). The revised WHO classification of hematopoietic and lymphoid tissues also included two entities associated with KSHV, the HHV8-positive diffuse large B-cell lymphoma, NOS and the HHV8-positive germinotropic lymphoproliferative disorder. KSHV-associated neoplasms usually develop in severely immunocompromised patients, and, as such, $\mathrm{KS}$ is, in many countries, an AIDS defining marker. The incidence of KS has sharply diminished after the introduction of anti-retroviral therapy, but has since stabilized in many countries [138]. In regions in which the virus is endemic, such as in Sub-Saharan Africa, HIV negative KS (classic KS or cKS) is one of the most common neoplasms in men [139].

MCD and PEL are extremely rare neoplasms. There are two main presentations of Castleman disease (CD), one in which reactive B cells only affect a single group of close lymph nodes, denoted 
as unicentric $(\mathrm{UCD})$ and $\mathrm{MCD}$, in which more than one group of lymph nodes are reactive. $\mathrm{CD}$ is also classified according to its microscopic morphology as hyaline-vascular (usually UCD), and plasma cell and plasmablastic (usually MCD). CD is not a true lymphoma, but rather a polyclonal B cell expansion and is thus considered an LPD. MCD is associated with HIV and KSHV co-infection, and if HIV is uncontrolled, $\mathrm{MCD}$ can have an aggressive clinical course and progress to an entity with cellular and viral monoclonality, in which it resembles a DLBCL [140]. On the contrary, PEL is an aggressive monoclonal B cell lymphoma with a poor clinical outcome, regardless of a down the line HIV control. PEL usually presents with lymphoid effusions in cavities, such as the pleura, peritoneum and pericardium. Post-transplant LPD and germinotropic LPD are also very rare and recently recognized [141,142], therefore, we could not find studies about them. Of interest is that in about $80 \%$ of PELs arising in AIDS patients, the tumor cells are co-infected with KSHV and EBV, a characteristic in common with germinotropic LPD [140].

\section{KSHV Prevalence and Morbidity in Latin America}

To our knowledge, there is no routine screening for KSHV infection in blood banks in LA countries, nor in the rest of the world, and the World Health Organization and the World Federation of Hemophilia do not recommend it [143]. Thus, one problem when assessing the incidence of KSHV infection is that there is not a reference standard assay, and comparative studies have often demonstrated great disparity [144]. Therefore, comparing different studies may be inaccurate. Blood donor-based studies from Brazil illustrate this point (see Table 2), while some studies from Sao Paulo report a prevalence of $3.8-4.6 \%$ [145-147], another found 26\% [148]; albeit, 1.1\% positives were found among health workers and $20.4 \%$ in HIV/AIDS patients from the same city [149]. A screening of blood donors from the Amazonian region also found a high prevalence of 31.3\% [150]. Pediatric studies found $7.6 \%$ positivity in Sao Paulo, 6.8\% in Campinas and 12\% in children of low-income families from Belem Pará [151-153]. Figure 3 summarizes studies about the KSHV prevalence among LA countries.

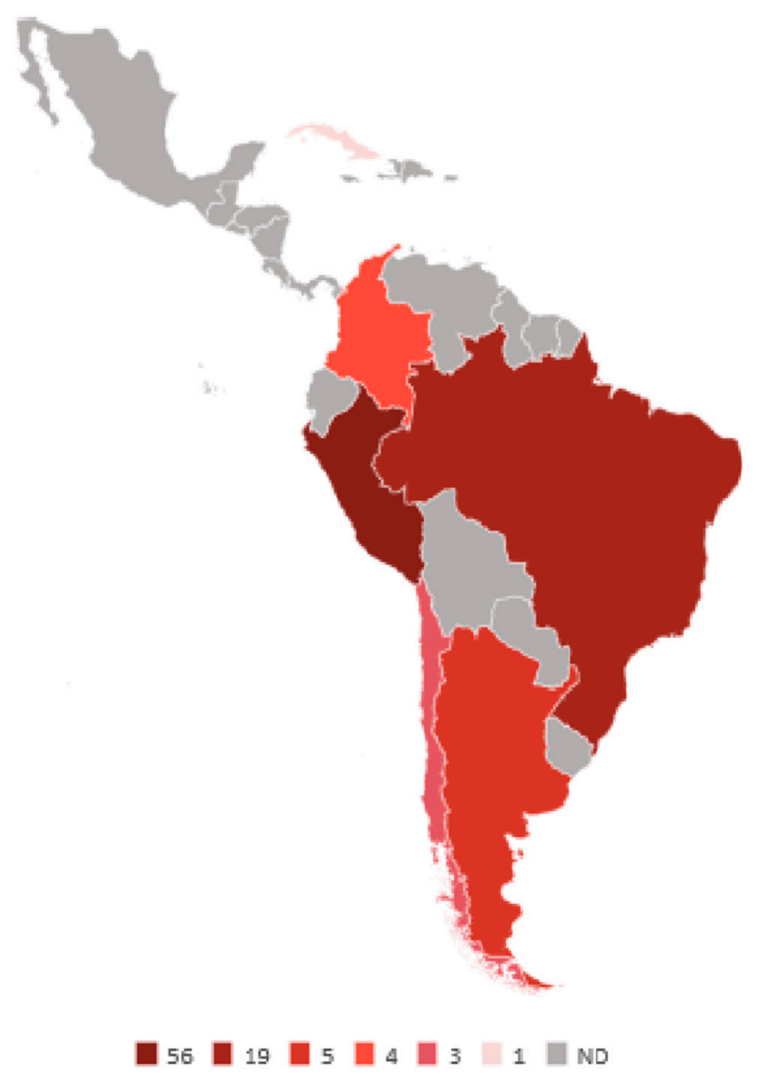

Figure 3. Kaposi sarcoma herpesvirus (KSHV) prevalence. Numeric values are in percentage. ND: not determined. 
Table 2. Summary of studies about KSHV.

\begin{tabular}{|c|c|c|c|c|}
\hline $\begin{array}{l}\text { Country } \\
\text { (Ref) }\end{array}$ & Type of Study & Methods & Results & Description of the Study \\
\hline Brazil [148] & Prevalence & EIA, IFA & $25.1 \% \mathrm{KSHV}+$ & $\begin{array}{l}\text { Screening of blood donors from Sao Paolo, Salvador and Manaos } \\
\text { (February-December 2003). } n=3493\end{array}$ \\
\hline Brazil [150] & Prevalence & EIA, IFA & $31.3 \% \mathrm{KSHV}+$ & $\begin{array}{l}\text { Screening of non-Amerindians blood donors from Mapuera and } \\
\text { Manaos (Amazon). } n=1120\end{array}$ \\
\hline Brazil [149] & Prevalence & IFA & $1.1 \% \mathrm{KSHV}+$ health care workers & $\begin{array}{l}\text { Screening of health care workers }(n=757) \text { and HIV/AIDS patients in } \\
\text { Sao Paolo }(1999-2008) .\end{array}$ \\
\hline Brazil [147] & Prevalence & EIA, IFA & $4.6 \% \mathrm{KSHV}+$ & $\begin{array}{l}\text { Screening of blood donors from Vitoria and Sao Paolo (January } \\
\qquad \text { 1998-April 1999). } n=747\end{array}$ \\
\hline Brazil [153] & Prevalence & EIA & $16.3 \% \mathrm{KSHV}+$ & $\begin{array}{l}\text { Screening of } 81 \text { low-income families from Belem Para, derived from a } \\
\text { previous rotavirus study. } n=467\end{array}$ \\
\hline Brazil [145] & Prevalence & IFA & $4 \% \mathrm{KSHV}+$ & Screening of blood donors from Sao Paolo. $n=400$ \\
\hline Brazil [146] & Prevalence & IFA & $3.8 \% \mathrm{KSHV}+$ & Screening of blood donors from Sao Paolo (2000-2002). $n=319$ \\
\hline Brazil [152] & Prevalence & ISH & $6.83 \% \mathrm{KSHV}+$ & $\begin{array}{l}\text { Screening of children (0-20 yo) from Campinas after removal of } \\
\text { either/both tonsil or adenoids. } n=293\end{array}$ \\
\hline Brazil [151] & Prevalence & IFA, WB & $9.35 \% \mathrm{KSHV}+$ & Screening of children (0-12 yo) from Rio de Janeiro. $n=171$ \\
\hline Brazil [154] & Case report & IFA & $\begin{array}{l}40 \text { yo female with UCD hyaline variety; } 62 \text { yo } \\
\text { with MCD mixed hyaline and plasma cell. } \\
\text { Patients died, because of progression to NHL }\end{array}$ & Description of 3 patients with CD of which two were KSHV+ \\
\hline Brazil [155] & Case report & $\begin{array}{l}\text { IHC, } \\
\text { Histology }\end{array}$ & $\begin{array}{l}41 \text { yo male with KSHV+ MCD co-presented } \\
\text { with KS. } 35 \text { yo male had no KSHV test }\end{array}$ & Description of two HIV/AIDS patients with MCD plasma cell variant \\
\hline Brazil [156] & Case report & $\mathrm{IHC}$ & 32 yo male with MCD plasmablastic variant & $\begin{array}{c}\text { Description of an HIV/AIDS patient with a history of KS in spite of } \\
\text { controlled HIV load }\end{array}$ \\
\hline Brazil [157] & Case report & IHC & 40 yo male with MCD plasmablastic variant & Description of an HIV/AIDS patient with MCD co-existing with KS \\
\hline Brazil [158] & Case report & Histology & 37 yo male with MCD. No KSHV or HIV test & Description of a patient with MCD plasma cell variant \\
\hline Brazil [159] & Case report & PCR & 44 yo male with PEL & Description of an HIV/AIDS patient \\
\hline Brazil [160] & CSS & PCR & One $(2 \%)$ bone marrow sample was KSHV+ & Screening of patients with multiple myeloma. $n=48$ \\
\hline
\end{tabular}


Table 2. Cont

\begin{tabular}{|c|c|c|c|c|}
\hline $\begin{array}{l}\text { Country } \\
\text { (Ref) }\end{array}$ & Type of Study & Methods & Results & Description of the Study \\
\hline $\operatorname{Arg}[146]$ & Prevalence & IFA & $3.6 \% \mathrm{KSHV}+$ & $\begin{array}{l}\text { Screening of blood donors from Buenos Aires, Bahia Blanca and } \\
\text { Cordoba (January 2000-December 2002). } n=1859\end{array}$ \\
\hline Arg [161] & Prevalence & PCR & $6.6 \% \mathrm{KSHV}+$ & $\begin{array}{l}\text { Screening of blood donors from Buenos Aires and San Salvador de } \\
\text { Jujuy. } n=772\end{array}$ \\
\hline $\operatorname{Arg}[162]$ & Prevalence & EIA & $7.8 \% \mathrm{KSHV}+$ & Screening of blood donors from Buenos Aires. $n=577$ \\
\hline $\operatorname{Arg}[163]$ & Prevalence & EIA & $6.4 \% \mathrm{KSHV}+$ & $\begin{array}{l}\text { Screening of repository samples from a previous cervical cancer } \\
\text { study from } 9 \text { countries. Concordia Argentina. } n=968\end{array}$ \\
\hline $\operatorname{Arg}[164]$ & CSS & PCR & One KSHV+ & Description of DLBCLs in HIV+ patients. $n=11$ \\
\hline $\operatorname{Arg}[165]$ & Case report & IFA, PCR & $\begin{array}{c}36 \text { yo male with MCD hyaline vascular. } \\
49 \text { yo male MCD plasmablastic } \\
\text { co-presenting with KS. }\end{array}$ & Report of two cases of KSHV+ MCD in HIV+ patients \\
\hline $\operatorname{Arg}[13]$ & Case report & PCR & 34 yo male with DLBCL EBV+ and KSHV+ & Description of a DLBCL in an HIV/AIDS patient \\
\hline Arg [166] & Case report & PCR & 72 yo male HIV- with KSHV+ PEL & Description of a PEL \\
\hline $\operatorname{Arg}[167]$ & Research study & IFA, PCR, Seq & I MCD and 1 PEL are described & KSHV genotyping \\
\hline Col [163] & Prevalence & EIA & $13.32 \% \mathrm{KSHV}+$ & $\begin{array}{l}\text { Screening of repository samples from a previous cervical cancer } \\
\text { study from } 9 \text { countries. } n=1883 \text { from Colombia (Bogota City) }\end{array}$ \\
\hline Chile [146] & Prevalence & IFA & $2.6 \% \mathrm{KSHV}+$ & Screening of blood donors from Santiago (2000-2002). $n=300$ \\
\hline Peru [168] & Prevalence & IFA & $56.2 \% \mathrm{KSHV}+$ & Screening of blood donors from one Hospital in Lima. $n=128$ \\
\hline Peru [169] & CSS & $\mathrm{IHC}$ & $\begin{array}{l}\text { Two UCD hyaline variety are reported as } \\
\text { KSHV+. One MCD plasma cell } \\
\text { was KSHV negative. }\end{array}$ & Description of CD patients from two hospitals in Lima. $n=10$ \\
\hline $\operatorname{Mex}[170]$ & CSS & $\mathrm{IHC}$ & Only one neoplasm was a KSHV+ MCD & $\begin{array}{l}\text { Description of CD patients from a Mexico City hospital } \\
\qquad(2000-2015) . n=39\end{array}$ \\
\hline $\operatorname{Mex}[171]$ & CSS & Histology & $\begin{array}{l}5 \text { MCDs are found but no test for KSHV } \\
\text { infection }\end{array}$ & $\begin{array}{l}\text { Description of CD patients from a Mexico City hospital between } \\
\text { 1996-2003. } n=11 .\end{array}$ \\
\hline $\operatorname{Mex}[172]$ & CSS & Histology & $1(4.8 \%)$ PEL & $\begin{array}{l}\text { Analysis of malignant neoplasms in HIV+ patients from a Mexico } \\
\text { City hospital (January 2005-July 2008). } n=21\end{array}$ \\
\hline
\end{tabular}


Table 2. Cont

\begin{tabular}{|c|c|c|c|c|}
\hline $\begin{array}{l}\text { Country } \\
\text { (Ref) }\end{array}$ & Type of Study & Methods & Results & Description of the Study \\
\hline Mex [173] & Case report & $\mathrm{IHC}$ & 73 yo HIV- female. EBV- lymphoma & Description of CD coexisting with a DLBCL. \\
\hline Mex [174] & Case report & IHC & 36 yo HIV+ male & $\begin{array}{c}\text { Description of a KS coexisting with a plasmablastic lymphoma and } \\
\text { previous history of CD. }\end{array}$ \\
\hline PR [175] & CSS & Histology & $\begin{array}{l}4.8 \% \text { developed neoplasia, Lymphomas are } \\
\text { reported but are not classified further }\end{array}$ & HIV+ patients from a Bayamon Institute. $n=3576$ \\
\hline Cuba [176] & Prevalence & IF, WB & $1.2 \% \mathrm{KSHV}+$ blood donors & Screening of blood donors $(n=171)$ and risk populations. \\
\hline Cuba [177] & Research Study & PCR, Seq & $\begin{array}{l}2 \text { PEL patients are included. No association } \\
\text { is found between specific KSHV strains and } \\
\text { any disease. }\end{array}$ & $\begin{array}{l}\text { Molecular classification of KSHV strains isolated from KS patients, } \\
\text { lymph node lesions and contacts of KS patients. } n=90\end{array}$ \\
\hline Cuba $[178]$ & Prevalence & IF & $16.9 \% \mathrm{KSHV}+$ & Screening of archival samples from a previous oral cancer study. $n=379$ \\
\hline Cuba [179] & Case report & Histology & $\begin{array}{l}4 \text { cases hyaline-vascular histological variety } \\
\text { and } 1 \text { case to plasmacellular variety. }\end{array}$ & Description of five cases of CD \\
\hline CR [163] & Prevalence & EIA & $9.81 \% \mathrm{KSHV}+$ & $\begin{array}{l}\text { Screening of repository samples from a previous cervical cancer study } \\
\text { from } 9 \text { countries. } n=1008 \text { from Costa Rica (Guanacaste province) }\end{array}$ \\
\hline
\end{tabular}


Argentina reports a prevalence of 3.6-7.4\% [146,161-163], higher for San Salvador Jujuy in the North West of the country (12.3\%), a region with a high population of immigrants and indigenous [161]. Higher prevalence for females than males was reported in two Brazilian studies, one pediatric (14.9:1) and one adult (3.7:1) [145,151], while in San Salvador Jujuy, the opposite was observed, with a male to female ratio of 3:1. More limited studies from Colombia $(n=25)$, Chile $(n=300)$ and Peru $(n=128)$ found $4 \%, 2.6 \%$ and $56.2 \%$ positivity, respectively $[146,168,180]$. In Peru, high endemicity was also challenged by a different study, in which the MSM high risk group was analyzed $(n=497)$, finding a seropositivity of $42.4 \%$ [181]. However, Peru is among the few countries from LA with multiple reports of cKS [182,183], including a large cohort of 126 cases that included pediatric cKS [184]. There are not large prevalence studies from Mexico, Central America and the Caribbean countries, a small screening of blood donors from Cuba $(n=171)$ found $1.2 \%$ KSHV positives [176]. Mexico reports KS as the most common neoplasm in AIDS patients, particularly before HAART [185,186]. For KSHV studies based on risk groups, see Table 3.

Table 3. KSHV in risk groups.

\begin{tabular}{|c|c|c|c|c|c|}
\hline \multirow{2}{*}{$\begin{array}{l}\text { Country } \\
\text { (Ref) }\end{array}$} & \multicolumn{5}{|c|}{ KSHV Prevalence Risk Groups } \\
\hline & HIV+ & FSW & Oral Cancer Patients & Close Contacts & MSM \\
\hline Cuba $[176,187]$ & $\begin{array}{c}20.8 \% \\
n=154\end{array}$ & & $\begin{array}{c}33.5 \% \\
n=191\end{array}$ & $\begin{array}{c}46.1-72.7 \% \\
\mathrm{X}=62.9 \% \\
n=35\end{array}$ & \\
\hline $\begin{array}{c}\text { Brazil } \\
{[149,150,188-192]}\end{array}$ & $\begin{array}{c}13.9-52.6 \% \\
X=21.8 \% \\
n=2358\end{array}$ & $\begin{array}{c}6.7 \% \\
n=90\end{array}$ & & & \\
\hline Honduras [193] & $\begin{array}{l}31.8 \% \\
n=22\end{array}$ & $\begin{array}{c}9.4 \% \\
n=96\end{array}$ & & & \\
\hline Colombia [180] & $\begin{array}{c}8 \% \\
n=25\end{array}$ & & & & \\
\hline Peru [181] & $\begin{array}{c}66.5 \% \\
n=197\end{array}$ & & & & $\begin{array}{c}26.7 \% \\
n=300\end{array}$ \\
\hline Argentina [194] & $\begin{array}{c}17.4 \% \\
n=144\end{array}$ & & & & \\
\hline
\end{tabular}

Prevalence of KSHV infection in specific risk groups, percentages and the number of tested individuals $(n)$ are given. When more than one study was found, the range of positives and the average $(X)$ are also given. FSW: female sex workers, MSM: men that have sex with men.

LA harbors distinct ethnic groups differentially distributed among different geographic regions in each country. Most urban populations are formed by mestizos and a minority of Caucasians, while some rural regions concentrate pure Amerindians or Afro-descendants. KSHV hyper endemicity is reported among LA indigenous populations and a hyper-endemicity area ( $30-100 \%$ prevalence) is reported among tribes inhabiting the South American lowlands of the Amazonas and the savannah (Figure 4 maps the prevalence of KSHV among Amerindian populations). For instance, Amazonian Amerindians from Ecuador were found $24 \%$ (the Siona, $n=41$ ) to $100 \%$ (the Huaorani, $n=38$ ) seropositive [195], while in Brazil different studies have found 56.8-79.1\% among Amerindians from the Pará state $(n=339-1270)[150,196-198]$ and 50-83\% $(n=110)$ among Amerindian tribes from transitional zones in central Brazil from Amazonian to the savannah. On the other hand, $0-14 \%$ positivity has been found in Amerindians from the South of Brazil $(n=85)$ [198]. Chacó Amerindians $(n=55)$ from Bolivia were $22 \%$ positive and $45 \%$ were positive in Paraguay [198]. 


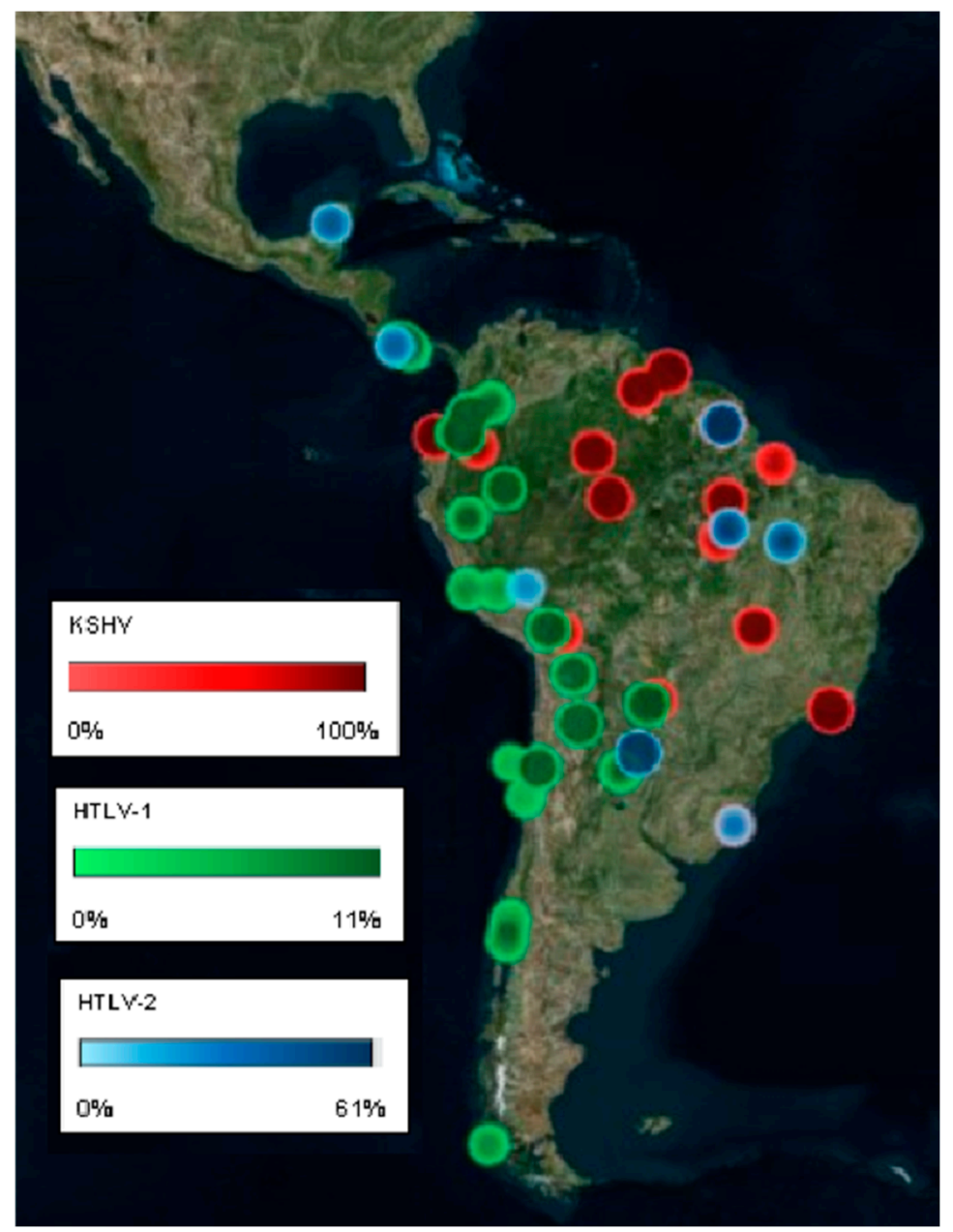

Figure 4. KSHV and human T-lymphotropic virus (HTLV) locoregional prevalence among Amerindian tribes.

Although our main aim was to document the incidence of lymphomas mediated by tumor viruses in LA, there are no such studies for KSHV in many LA countries, with most studies being about the prevalence of KS in HIV/AIDS patients. Additionally, because many of the reports are from the 1980s and 1990s, the studies only addressed the overall frequency of lymphomas, and lymphomas were only classified as Burkitt, Hodgkin and non-Hodgkin. Thus, both MCD and PEL seem more common after HAART, but they may have been under-diagnosed in early studies. Furthermore, KSHV-associated neoplasms most often are reported based on their histological and clinical characteristics, lacking confirmatory tests for viral infection. KSHV-associated lymphomas are reported from Brazil, Argentina and Peru. We found five cases of MCD in Brazil, mostly of the plasmablastic variety, and one mixed plasmablastic and hyaline [154-158]. Although KSHV infection was not assessed in all cases, four cases were in HIV infected individuals and in three cases MCD co-presented with KS. There was also a case of PEL in an HIV positive patient [159], and a multiple myeloma patient with a bone marrow KSHV PCR positive [160]. We found three KSHV positive MCD from Argentina, two PEL and two KSHV positive DLBCL, all in HIV positive patients [13,165-167]. One of the DLBCL was also positive to EBV infection [164]. On the other hand, a screening of a series of cases of B cell lymphomas arising in HIV/AIDS patients $(n=49)$ did not find any KSHV positive supporting the rarity of these kind of neoplasms [199]. Peru reported two cases of UCD hyaline that were KSHV positive by IHC [169]. We found only one PEL and three MCD reported from Mexico [170,172,173], and two PEL and one MCD from Cuba [179,187]. Figure 5 shows KSHV positive PEL and MCD. 


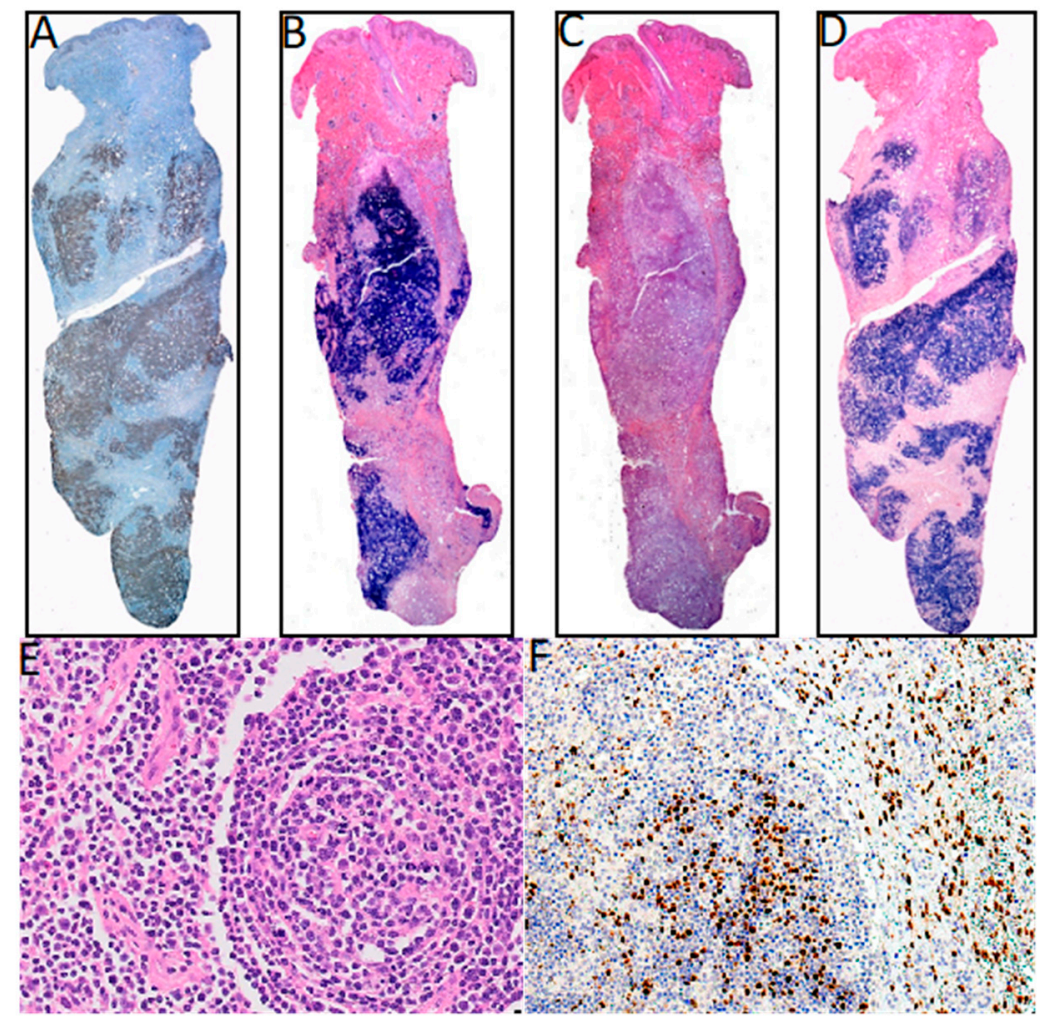

Figure 5. KSHV associated lymphomas. (A-D) Primary effusion lymphoma KSHV and EBV positive. (A) KSHV LANA (latency-associated nuclear antigen) staining. (B) Lambda light chain staining. (C) Kappa light staining. (D) EBER in situ hybridization. (E,F) Multicentric Castleman disease. (E) Hematoxylin-Eosin staining. (F) KSHV LANA staining, magnification 40×.

There are five major KSHV genotypes described (A, B, C, D and E), mainly based on the hypervariable regions of the oncogenic $\mathrm{K} 1$ gene. Interestingly, in the series of studies from LA, while genotypes $\mathrm{A}$, B and C [167,177,190,200-202] were described in neoplasms or HIV positive cases, subtype E has been the sole genotype found in Amerindians from Ecuador, Brazil and French Guiana [190,195,197,203-205]. Genotypes A and C are prevalent in Europe and North America, while genotype B is more prevalent in individuals with African ancestry [195]. Thus, one plausible explanation for the low incidence of KSHV-induced neoplasms (including cKS) among South American Amerindians is a low oncogenicity of the KSHV genotype E. Indeed, only two KS reported in Peru shared genotype E [204], while KSHV $\mathrm{A}$ and $\mathrm{B}$ genotypes have been isolated from Brazilian and Argentinian patients with European ancestry [201,206]. To our knowledge, the tumorigenic activity of the genotype E K1 has not been tested in vitro or in animal models, and it is not clear why KSHV would become more attenuated in South American Amerindians, but not in other populations with an equally prevalent KSHV infection, such as those from Uganda or Zambia.

\section{Human T-Cell Lymphotropic Virus}

HTLV belongs to the family Retroviridae, genus Deltaretrovirus, and, as such, its genome consists of two identical copies of positive sense single stranded RNA that during its life cycle is converted into double stranded DNA and inserted into the DNA of the human host cell. This integrated form is referred to as the provirus, and HTLV predominantly exists in the host as a cell-associated provirus. Indeed, infected cells hardly produce any virus and plasma viral load is usually undetectable. There are two main types of HTLV infecting humans, HTLV-1 that preferentially infects CD4+, but also CD8+ T-lymphocytes, and HTLV-2 that preferentially infects CD8+ T-lymphocytes. Two other HTLV types have been described in Africa, but today, it is not clear whether HTLV-3 and HTLV-4 can be transmitted 
from human to human or are exclusively zoonotic, and no clinical disease has been associated with these two novel isolates thus far [207].

HTLV-1 and -2 are very similar in terms of genome structure and replication patterns, but they are strikingly different in terms of clinical impact and geographical distribution. HTLV-1 is present throughout the world with regions of high endemicity together with low prevalence in neighboring zones. Major endemic regions include Southwest of Japan, LA and some areas of West Africa [208,209]. Ten to twenty million people are estimated to be infected with HTLV-1. However, the world prevalence of HTLV-1 is largely unknown, since most published studies are performed on blood donors and there are not population-based studies. The epidemiology and pathogenic potential of HTLV-2 infection are less well characterized. HTLV-2 is present in many world areas, and high HTLV-2 seroprevalence has been reported in indigenous populations in Africa and Amerindians from Central and South America, as well as among IVDU in Europe and North America [209]. Moreover, six genotypes have been found for HTLV-1 based on the genomic sequences of the long terminal repeats, A (also called the Cosmopolitan strain, because of its worldwide distribution) to $G$ (the rest of them with a somehow more restricted geographical distribution) and five for HTLV-2, A to E [210].

HTLV-1 infection has been associated with adult T cell leukemia/lymphoma (ATLL) and a subacute myelopathy known as tropical spastic paraparesis or HTLV-1-associated myelopathy (TSP/HAM). Although most HTLV-1 carriers are asymptomatic, about $5 \%$ of them will develop clinical complications, including TSP/HAM and ATLL. Both diseases are severe and produce progressive incapacitation or death. In addition to ATLL and TSP/HAM, infection by HTLV-1 also leads to a broad spectrum of inflammatory diseases with significant morbidity, such as uveitis, arthritis, myositis, infective dermatitis, Strongyloides stercoralis infection and crusted scabies $[209,211]$. The mechanisms leading to them are currently unknown. On the contrary, and in spite of sharing $60 \%$ of genetic homology, no disease has been consistently associated with HTLV-2 infection, although sporadic cases of subacute myelopathy or hematological malignancies have been reported [209].

\section{HTLV Prevalence and Morbidity in Latin America}

When assessing the viral prevalence, we found that the majority of studies are based on immunological methods that do not discriminate between HTLV-1 and HTLV-2 (referred to as HTLV). The Caribbean basin is usually considered endemic to HTLV infection, perhaps because early 1980s studies documented several cases of ATLL from black immigrants from the Caribbean islands [212,213]. There are several studies from Cuba and Dominican Republic that tried to confirm that high endemicity and morbidity. Surprisingly, three sero-epidemiological studies carried on Cuban blood donors found $0.25 \%, 0.27 \%$ and $0.99 \%$ HTLV positivity, even though they included a significant number of black Cubans [214-216]. Dominican Republic and Puerto Rico report $2.5 \%$ and $0.2 \%$ positivity in blood donors, respectively [217-219]. Higher prevalence has been reported for risk groups. A retrospective study from 1996 to 2007 from two sentinel hospitals from Havana and Matanzas Cuba that registered all lymphoid neoplasms, reported only five ATLL cases [220]. On the contrary, in spite of multiple reports about TSP/HAM in Dominican Republic and Puerto Rico [218,221-223], we could not find a single ATLL case. Although it is not clear which is the most prevalent subtype, HTLV-1 is almost exclusively the one reported [216,220,224,225]. Thus, the low incidence of ATLL may be due to the low prevalence of HTLV infection, or the scarcity of other needed co-factors. For a summary of data see Table 4. 
Table 4. Summary of HTLV studies.

\begin{tabular}{|c|c|c|c|c|}
\hline $\begin{array}{l}\text { Country } \\
\text { (Ref) }\end{array}$ & Type of Study & Methods & $\begin{array}{l}\text { HTLV Association } \\
\text { (Main Finding) }\end{array}$ & Description of Study \\
\hline Mexico [226] & Prevalence & $\mathrm{PA}, \mathrm{WB}$ & $0.39 \%$ HTLV-1/2+ & Screening of blood donors from Monterrey. $n=1017$ \\
\hline Mexico [227] & Prevalence & EIA & $2.8 \%$ HTLV+ & Screening of emergency room patients from Mexico City. $n=909$ \\
\hline Mexico [228] & Prevalence & EIA, PA, WB & $0.3 \%$ HTLV+ healthy women & Screening of healthy women $(n=662) \&$ cervical cancer patients from Yucatan. \\
\hline Panama [229] & Prevalence & EIA & $5 \%$ HTLV+ & Screening sera from previous studies (meningitis and enterovirus). $n=754$ \\
\hline Panama [230] & Case report & EIA, WB & HTLV-1+ & Description of ATLL patient \\
\hline Panama [231] & CSS & EIA, IFA, WB, RIPA & $\begin{array}{c}7 \text { cases HTLV+ } \\
3 \text { cases confirmed ATLL }\end{array}$ & Analysis of hematologic malignancies. $n=136$ \\
\hline Hond [232] & Prevalence & EIA, WB, PCR & $\begin{array}{l}\text { 8.1\% HTLV-1+ of non- mestizos } \\
0.5 \% \text { HTLV-1+ of mestizos }\end{array}$ & Screening of blood donors from 15 cities of the Atlantic coast $(n=2651)$ \\
\hline Hond [233] & Prevalence & EIA, WB & $\begin{array}{l}0.3 \% \text { HTLV- } 1+ \\
1.1 \% \text { HTLV-2+ }\end{array}$ & Screening of healthy individuals from Tegucigalpa and San Pedro Sula. $n=899$ \\
\hline Hond [234] & Case report & EIA & HTLV+ & Description of ATLL patient \\
\hline Nicar [235] & Technical paper & EIA, WB, PCR & $0.24 \%$ HTLV- $1+$ & Test of a new assay in blood donors. $n=410$ \\
\hline Cuba [215] & Prevalence & EIA, WB, RIPA & $0.27 \% \mathrm{HTLV}+$ & Screening of blood donors. $n=2579$ \\
\hline Cuba [216] & Prevalence & EIA, WB & $0.99 \%$ HTLV-1+ blood donors & Screening of blood donors $(n=1409) \&$ risk groups. \\
\hline Cuba [214] & Prevalence & PA, EIA, IF, WB & $\begin{array}{l}0.25 \% \text { HTLV+ in blood donors } \\
0.72 \% \text { in patients }\end{array}$ & $\begin{array}{c}\text { Screening of blood donors }(n=2429) \& \text { patients with hematological and } \\
\text { non-hematological disorders from } 13 \text { provinces. }\end{array}$ \\
\hline Cuba [178] & Prevalence & EIA & $4.2 \%$ HTLV- $1+$ & Screening of archival samples from a previous oral cancer study. $n=379$ \\
\hline Cuba [220] & CSS & EIA, WB, PCR & 5 ATLL reported & Hematological neoplasms in 2 sentinel centers from Havana \& Matanzas, (1997-2006). $n=1281$ \\
\hline DR [218] & Prevalence & EIA, WB, RIPA, IFA & $\begin{array}{l}2.5 \% \mathrm{HTLV}+\text { low risk group } 0 \% \\
\text { Children }\end{array}$ & Screening of low $(n=2552)$ and high risk populations. \\
\hline PR [219] & Prevalence & Undisclosed & $0.25 \%$ HTLV+ & Database search of transfusion transmitted pathogens in blood donors. $n=400$ \\
\hline PR [217] & Prevalence & EIA, WB, RIPA & $\begin{array}{l}\text { O.2\% HTLV- } 1+ \\
1 \% \text { IVDU }\end{array}$ & Archival samples from a Dengue surveillance study \& blood donors from Ponce. $n=1881$ \\
\hline Venez [236] & Prevalence & EIA, WB, PCR & $0.2 \%$ HTLV+ & Screening of blood donors from Caracas. $n=23,413$ \\
\hline Venez [237] & Prevalence & EIA & $\begin{array}{l}1 \% \text { HTLV+ Caracas } \\
13.7 \% \text { in the Amazonas }\end{array}$ & Screening of healthy individuals. $n=769$ \\
\hline Venez [238] & Prevalence & EIA, WB & $0.58 \%$ HTLV+ & Screening of healthy individuals from an immunology clinic in Maracay City. $n=514$ \\
\hline
\end{tabular}


Table 4. Cont.

\begin{tabular}{|c|c|c|c|c|}
\hline $\begin{array}{l}\text { Country } \\
\text { (Ref) }\end{array}$ & Type of Study & Methods & $\begin{array}{l}\text { HTLV Association } \\
\text { (Main Finding) }\end{array}$ & Description of Study \\
\hline Colom [239] & Prevalence & Undisclosed & $0.3 \%$ HTLV+ & Databases search of Colombian blood banks (2001-2014). $n=5,105,159$ \\
\hline Colom [240] & Prevalence & EIA & $0.24 \% \mathrm{HTLV}+$ & Databases search of Cali blood banks (2008-2014). $n=77,117$ \\
\hline Colom [241] & Prevalence & $\mathrm{PA}, \mathrm{WB}$ & $\begin{array}{c}0.7 \% \text { HTLV- } 1+\text { children } \\
5.3 \% 20 \text { y \& older } \\
7.8 \% \text { IVDU }\end{array}$ & Screening of random subjects from Tumaco. $n=1077$ \\
\hline Colom [242] & Prevalence & EIA & $0.3 \%$ HTLV+ & Screening of blood donors from Bogota (1999-2004). $n=8913$ \\
\hline Colom [243] & Prevalence & EIA, WB & $\begin{array}{l}\text { 0.176\% HTLV+ } \\
\text { HTLV-1:HTLV-2 (3:1) }\end{array}$ & Databases search of Medellin blood banks (2014-2018). $n=52,159$ \\
\hline Colom [244] & Prevalence & EIA, WB & $\begin{array}{c}\text { 0.06\% HTLV+ } \\
\text { HTLV-1:HTLV-2 (8:1) }\end{array}$ & Database search of one Medellin blood bank (2014-2015). $n=14,423$ \\
\hline Colom [245] & CSS & EIA, RIA, WB & $\begin{array}{l}4.3 \% \mathrm{HTLV}+\text { lowland } \\
0.9 \% \text { upland regions }\end{array}$ & Comparison between Coastal and high-altitude towns. $n=670$ \\
\hline Colomb [246] & Case report & EIA & HTLV+ ATLL & HTLV+ ATLL co-presenting with a verrucous carcinoma \\
\hline Colom [247] & Case Report & EIA, WB, PCR & $\begin{array}{l}\text { Clinical presentation similar to } \\
\text { ATLL from Japan }\end{array}$ & Description of six ATLL patients from Cali. \\
\hline Colom [248] & Case Report & EIA, WB & HTLV-1+ ATLL & Description of two ATLL patients \\
\hline Colom [249] & Case control & EIA, WB & $\begin{array}{c}100 \% \text { of TSP/HAM \& ATLL } \\
\text { cases were HTLV- } 1+\end{array}$ & Screening for auto-antibodies in TSP/HAM $(n=37)$ and ATLL $(n=10)$ patients. \\
\hline Ecuador [250] & Prevalence & EIA, IF, WB & $3.5 \%$ HTLV+ & Screening of random subjects from the Esmeralda Province. $n=227$ \\
\hline Ecuador [251] & Prevalence & EIA, WB & $\begin{array}{c}2.4 \% \mathrm{HTLV}+\text { in Afro } \\
\text { descendant, } 0 \% \text { in the Chachis }\end{array}$ & Screening of random subjects from the Esmeralda Province. $n=142$ \\
\hline Ecuador [252] & Prevalence & EIA, RIPA, WB & $\begin{array}{c}0.42 \% \text { HTLV- } 1+ \\
\text { in continental regions } \\
1.57 \% \text { in Galapagos Island }\end{array}$ & Screening of healthy individuals $(n=744)$ and risk groups throughout Ecuador \\
\hline Peru [253] & Prevalence & EIA, WB & $3.4 \% \mathrm{HTLV}+$ & Databases search of blood banks from Abancay (2010-2015). $n=2895$ \\
\hline Peru [254] & Prevalence & EIA, WB & $0.9 \%$ HTLV- $1+$ & Databases search of blood banks from Arequipa in 2005. $n=2732$ \\
\hline Peru [255] & Prevalence & EIA, WB & $\begin{array}{c}0.3 \% \text { HTLV- } 1+ \\
0 \% \text { HTLV-2 }\end{array}$ & Screening of random subjects from 24 cities. $n=1535$ \\
\hline Peru [256] & Prevalence & EIA & $1.7 \%$ HTLV-1+ & Screening of pregnant women from Lima. $n=2492$ \\
\hline Peru [257] & Case report & Undisclosed & HTLV-1+ & Acute liver failure as presentation of ATLL. \\
\hline
\end{tabular}


Table 4. Cont.

\begin{tabular}{|c|c|c|c|c|}
\hline $\begin{array}{l}\text { Country } \\
\text { (Ref) }\end{array}$ & Type of Study & Methods & $\begin{array}{l}\text { HTLV Association } \\
\text { (Main Finding) }\end{array}$ & Description of Study \\
\hline Peru [258] & Case report & Undisclosed & HTLV-1+ & Co-presentation of ATLL and strongyloidiasis. \\
\hline Peru [259] & Case report & WB & HTLV+ & Description of three ATLL patients. \\
\hline Peru [260] & Case report & EIA, WB & $\begin{array}{l}\text { 3/7 tumors EBV+ } \\
\text { HTLV provirus in tumor was } \\
\text { not assessed }\end{array}$ & Description of seven patients with DLBCL in HTLV-1 carriers. \\
\hline Peru [261] & Case report & EIA HTLV-1 & HTLV-1+ & Description of two cases of ATLL and concomitant S. stercoralis. \\
\hline Peru [262] & Case report & EIA, WB, IH & HTLV-1+ & Description of four patients with gastric ATLL \\
\hline Peru [263] & Case Report & EIA, PCR & HTLV-1+ & Description of one ATLL patient \\
\hline Chile [264] & Prevalence & EIA, IF, PCR & $\begin{array}{c}\text { 0.12\% HTLV+ } \\
\text { HTLV-1: HTLV-2 (7.3:1) }\end{array}$ & Databases search of blood banks from 12 Chilean regions (2011-2013). $n=694,016$ \\
\hline Chile [265] & Prevalence & EIA, IF, PCR & $\begin{array}{l}0.24 \% \text { HTLV- } 1+ \\
\text { Female:Male (3:1) }\end{array}$ & Databases search of blood banks from Valdivia (May 2009-May 2010). $n=6237$ \\
\hline Chile [266] & CSS & EIA, SB, PCR & $\begin{array}{l}\text { Clinical and laboratory features } \\
\text { of HTLV-I+ ATLL }\end{array}$ & Description of ATLL patients from the Santiago area (1989-1998). $n=26$ \\
\hline Chile [267] & Case report & EIA, PA, PCR & $\begin{array}{l}\text { Intestinal involvement and } \\
\text { progression into } \\
\text { a leukemic phase }\end{array}$ & Description of one ATLL patient \\
\hline Chile [268] & Case report & EIA, SB, PCR & $\begin{array}{l}\text { Clinical and laboratory features } \\
\text { of HTLV-I+ ATLL }\end{array}$ & Description of nine ATLL patients \\
\hline Chile [269] & Case report & EIA, WB & Provirus was not assessed & Description of an ATLL with Reed-Sternberg cells \\
\hline Chile [270] & Case report & EIA, WB, SB & HTLV-1+ ATLL & Description of three ATLL patients co-presenting with TSP/HAM \\
\hline Chile [271] & Case report & EIA, CSF, SB & HTLV-1+ ATLL & ATLL case preceded by TSP/HAM \\
\hline Chile [272] & Case report & EIA, SB & HTLV-1+ ATLL & Chilean immigrant in Spain with ATLL \\
\hline Chile [273] & CSS & PCR, RFLP & $\begin{array}{c}\text { 18.2\% HTLV+ (15 HTLV-1 } \\
\text { \& } 1 \text { HTLV-2) }\end{array}$ & Analysis of hematological malignancies from Valdivia. $n=88$ \\
\hline Chile [274] & CSS & Undisclosed & $\begin{array}{l}23 \text { neoplasia of T cells } \\
11 \text { HTLV-1+ ATLL }\end{array}$ & Analysis of chronic LPD from one hospital in Santiago (1999-2001). $n=132$ \\
\hline Chile [275] & Case report & WB & HTLV+ ATLL & ATLL case in an HIV+ patient \\
\hline Parag [276] & Prevalence & PA, EIA, WB, RIPA & 0\% HTLV+ healthy & Screening of healthy volunteers $(n=338)$ and risk groups. \\
\hline Urug [277] & Prevalence & EIA & $0.13 \% \mathrm{HTLV}+$ & Data from the National Registry Report of blood banks, 2012-2014. $n=297,371$ \\
\hline
\end{tabular}


Table 4. Cont

\begin{tabular}{|c|c|c|c|c|}
\hline $\begin{array}{l}\text { Country } \\
\text { (Ref) }\end{array}$ & Type of Study & Methods & $\begin{array}{l}\text { HTLV Association } \\
\text { (Main Finding) }\end{array}$ & Description of Study \\
\hline Urug [278] & Prevalence & PA, IFA, WB, RIPA & $0.75 \%$ HTLV- $1+$ & Screening of blood donors $(n=266)$ and risk groups. \\
\hline Urug [279] & Case report & Undisclosed & HTLV-1+ & ATLL of a Peruvian immigrant co-presenting with multiple parasitosis. \\
\hline Arg [280] & Prevalence & PA, EIA, WB & $\begin{array}{c}0.9 \% \text { HTLV- } 1+ \\
0.04 \% \text { HTLV-2+ }\end{array}$ & Databases search of blood banks from Jujuy city. $n=14,228$ \\
\hline $\operatorname{Arg}[281]$ & Prevalence & EIA, PA, IFA, WB & $\begin{array}{l}0.05 \% \text { HTLV- } 1+ \\
0.03 \% \text { HTLV-2+ }\end{array}$ & Databases search of blood banks from Buenos Aires. $n=12,891$ \\
\hline Arg [282] & Prevalence & $\begin{array}{c}\text { EIA, PA, WB, } \\
\text { Phylogenetic study }\end{array}$ & $\begin{array}{c}0.011 \% \text { HTLV-1+ } \\
0.021 \% \text { HTLV-2+ } 1 \\
\text { HTLV-1 Subtype A } \\
\text { HTLV-2 Subtype B }\end{array}$ & Databases search of blood banks from Corrientes. $n=9422$ \\
\hline $\operatorname{Arg}[283]$ & Prevalence & EIA, PA & $0.11 \% \mathrm{HTLV}+$ & Database search of a blood bank from Cordoba. $n=20,210$ \\
\hline Arg [284] & CSS & EIA, PA, WB & $\begin{array}{l}0.028 \% \text { HTLV-1+ } \\
0,025 \% \text { HTLV-2+ }\end{array}$ & Databases search of blood banks from 9 different provinces. $n=123,233$ \\
\hline Arg [285] & Prevalence & PA, IF, WB, PCR & $0.19 \%$ HTLV-1/2+ & Databases search of blood banks from Buenos Aires. $n=2050$ \\
\hline $\operatorname{Arg}[286]$ & Prevalence & $\mathrm{PA}, \mathrm{WB}$ & $0.06 \%$ HTLV-1+ & Databases search of blood banks from Buenos Aires. $n=12,846$ \\
\hline $\operatorname{Arg}[287]$ & Prevalence & $\mathrm{PA}, \mathrm{WB}$ & $\begin{array}{l}0.036 \% \text { HTLV- } 1+ \\
0.01 \% \text { HTLV-2+ }\end{array}$ & Databases search of blood banks from Buenos Aires. $n=19,426$ \\
\hline $\operatorname{Arg}[288]$ & Prevalence & $\mathrm{PA}, \mathrm{WB}$ & $\begin{array}{l}0.035 \% \text { HTLV- } 1 \\
0.007 \% \text { HTLV-2 } \\
\end{array}$ & Databases search of blood banks from Buenos Aires. $n=28,897$ \\
\hline Arg [289] & Prevalence & PA, IF & $0.26 \%$ HTLV-1 & Databases search of blood banks from Cordoba. $n=5476$ \\
\hline Arg [290] & Prevalence & PA, IF, WB & 0\% HTLV-1 & Databases search of blood banks from Santa Fe and Santiago del Estero. $n=1327$ \\
\hline Arg [291] & Prevalence & PA, EIA, WB, PCR & $\begin{array}{l}0.033 \% \text { HTLV- } 1+ \\
0.013 \% \text { HTLV-2+ } \\
\end{array}$ & Databases search of blood banks from Buenos Aires. $n=76,246$ \\
\hline Arg [292] & Prevalence & Undisclosed & $\begin{array}{c}1.0 \% \text { HTLV+ Jujuy } \\
0.7 \% \text { HTLV+ Salta } \\
0.6 \% \text { HTLV+ Formosa }\end{array}$ & Databases search of blood banks from Northern and Center regions. $n=130,599$ \\
\hline $\operatorname{Arg}[293]$ & Prevalence & PA, WB, PCR & $\begin{array}{l}0.034 \% \text { HTLV- } 1+ \\
0.014 \% \text { HTLV-2+ }\end{array}$ & Databases search of blood banks from Buenos Aires. $n=86,238$ \\
\hline Arg [294] & Prevalence & $\mathrm{PA}, \mathrm{WB}$ & $\begin{array}{l}0.03 \% \text { HTLV-1+ } \\
0.05 \% \text { HTLV-2+ }\end{array}$ & Databases search of blood banks from Santa Fe. $n=9425$ \\
\hline Arg [295] & Prevalence & EIA, PA, WB & $0.00072 \% \mathrm{HTLV}+$ & Databases search of blood banks from Misiones. $n=6912$ \\
\hline
\end{tabular}


Table 4. Cont.

\begin{tabular}{|c|c|c|c|c|}
\hline $\begin{array}{l}\text { Country } \\
\text { (Ref) }\end{array}$ & Type of Study & Methods & $\begin{array}{l}\text { HTLV Association } \\
\text { (Main Finding) }\end{array}$ & Description of Study \\
\hline Urug [278] & Prevalence & PA, IFA, WB, RIPA & $0.75 \%$ HTLV-1+ & Screening of blood donors $(n=266)$ and risk groups. \\
\hline Arg [296] & Prevalence & EIA & $\begin{array}{l}0.07 \% \text { HTLV- } 1+ \\
0.03 \% \text { HTLV-2+ }\end{array}$ & Databases search of blood banks from Buenos Aires. $n=28,483$ \\
\hline Arg [297] & Prevalence & EIA & $0.191 \%$ HTLV+ & Screening of pregnant women from Córdoba. $n=3143$ \\
\hline Arg [298] & Prevalence & $\begin{array}{l}\text { PVT, IH, Proviral } \\
\text { DNA integration }\end{array}$ & $\begin{array}{c}5 \text { cases HTLV- } 1+\text { from native } \\
\text { American: ATLL }\end{array}$ & 34 cases of lymphoma resembling ATLL \\
\hline Arg [299] & Case Report & Undisclosed & $\begin{array}{l}\text { HTLV-1+ of Guinean origin } \\
\text { NHL B and one T without } \\
\text { phenotype of ATLL }\end{array}$ & Association of B-cell lymphoma and T-cell lymphoma in HTLV-1 infection. \\
\hline Arg [300] & $\begin{array}{l}\text { Case report } \\
5 \text { cases }\end{array}$ & Undisclosed & HTLV-1+ & ATLL cases \\
\hline Arg [301] & 2 cases report & Undisclosed & HTLV-1+ & ATLL from 2 asymptomatic brothers \\
\hline Brazil [302] & Prevalence & EIA, PCR & $\begin{array}{c}0.1 \% \text { HTLV+ } \\
\text { HTLV-1:2 (2:1) }\end{array}$ & Databases search of blood banks from Riberao Preto, Sao Paulo. $n=301,400$ \\
\hline Brazil [303] & Prevalence & EIA, WB & $\begin{array}{c}0.04 \% \text { HTLV+ in South } \\
1 \% \text { in Northeast }\end{array}$ & Databases search of blood banks from 27 urban cities. $n=6,218,619$ \\
\hline Brazil [304] & Prevalence & EIA, WB, PCR & 1.76\% HTLV-1+ Subtype A & Databases search of blood banks from Salvador. $n=1385$ \\
\hline Brazil [305] & Prevalence & EIA, WB & $0.08 \%-0.2 \%$ HTLV+ & Databases search of blood banks from Sao Paulo, Minas Gerais \& Pernambuco. $n=281,760$ \\
\hline Brazil [306] & Prevalence & EIA & $0.63 \% \mathrm{HTLV}+$ & Databases search of blood banks from Southwest Bahia. $n=34,400$ \\
\hline Brazil [307] & Prevalence & EIA & $0.09 \%$ HTLV+ & Databases search of blood banks from Goiás. $n=137,209$ \\
\hline Brazil [308] & Prevalence & EIA & $\begin{array}{l}0.77 \% \text { HTLV- } 1+ \\
0.025 \% \text { HTLV-2+ }\end{array}$ & Databases search of blood banks from Salvador Bahia. $n=233,876$ \\
\hline Brazil [309] & Prevalence & PCR & $\begin{array}{l}1.4 \% \text { HTLV-1 } \\
0.5 \% \text { HTLV-2 }\end{array}$ & Databases search of blood banks from Belém, Pará. $n=1059$ \\
\hline Brazil [310] & Prevalence & EIA, PCR & $\begin{array}{c}0.059 \% \text { HTLV- } 1+ \\
0.037 \% \text { HTLV-2+ } \\
\text { HTLV-1 subgroup A }\end{array}$ & Databases search of blood banks from Piauí. $n=37,306$ \\
\hline Brazil [311] & Prevalence & EIA, WB & $0.13 \%$ HTLV+ & Databases search of blood banks from Manaus. $n=87,402$ \\
\hline Brazil [312] & Prevalence & EIA & $0.58 \%$ HTLV+ & Databases search of blood banks from Marajó Island. $n=1899$ \\
\hline Brazil [313] & Prevalence & EIA & $1.48 \%$ HTLV-1+ & Databases search of blood banks from Salvador Bahía. $n=3451$ \\
\hline
\end{tabular}


Table 4. Cont.

\begin{tabular}{|c|c|c|c|c|}
\hline $\begin{array}{l}\text { Country } \\
\text { (Ref) }\end{array}$ & Type of Study & Methods & $\begin{array}{l}\text { HTLV Association } \\
\text { (Main Finding) }\end{array}$ & Description of Study \\
\hline Brazil [314] & Prevalence & EIA & $\begin{array}{l}0.019 \% \text { HTLV- } 1+ \\
0.005 \% \text { HTLV-2+ }\end{array}$ & Databases search of blood banks from Fortaleza. $n=679,610$ \\
\hline Brazil [315] & Prevalence & EIA & $0.1 \%$ HTLV+ & Databases search of blood banks from Minas Gerais. $n=3,249,944$ \\
\hline Brazil [316] & Prevalence & EIA & $0.02 \% \mathrm{HTLV}+$ & Databases search of blood banks from Uberata. $n=147,489$ \\
\hline Brazil [317] & Prevalence & EIA & $\begin{array}{c}0.1 \% \text { HTLV- } 1 \\
0.002 \% \text { HTLV-2 }\end{array}$ & Databases search of blood banks from Belo Horizonte. $n=422,600$ \\
\hline Brazil [318] & CSS & EIA & $0.02 \% \mathrm{HTLV}+$ & Databases search of blood banks from Riberao Preto. $n=377,243$ \\
\hline Brazil [319] & Prevalence & EIA, WB & $0.15 \%$ HTLV+ & Databases search of blood banks from Maranhao. $n=365,564$ \\
\hline Brazil [320] & Prevalence & EIA, WB & $0.66 \%$ HTLV+ & Databases search of blood banks from Rio Branco. $n=11121$ \\
\hline Brazil [321] & Prevalence & EIA & $0.3 \% \mathrm{HTLV}+$ & Databases search of blood banks from Sao Paulo. $n=351,639$ \\
\hline Brazil [322] & Prevalence & EIA, WB & $0.17 \%$ HTLV+ & Databases search of blood banks from Sao Paulo. $n=17063$ \\
\hline Brazil [323] & CSS & Undisclosed & $\begin{array}{l}83 \text { ATLL (26 smoldering, } \\
23 \text { chronic, } 16 \text { acute, } \\
13 \text { lymphoma and five } \\
\text { primary cutaneous) }\end{array}$ & ATLL treatment and response in Salvador, Bahia \\
\hline Brazil [324] & CSS & EIA, WB, PCR, IH & HTLV-1+ & 52 cases ATLL from Salvador, Bahía. \\
\hline Brazil [325] & Case report & EIA, WB, IH & HTLV-1 in CSF + ATLL & Simultaneous development of ATLL and HAM/TSP in a pediatric patient with IDH. \\
\hline Brazil [326] & CSS & EIA, WB & HTLV+ ATLL & Prognostic Factors of 72 ATLL. \\
\hline Brazil [327] & Case report & EIA, WB, Nested PCR & $\begin{array}{l}\text { HTLV-1+ ATLL with } \\
\text { monoclonal integration. }\end{array}$ & ATLL case \\
\hline Brazil [328] & Case report & $\begin{array}{l}\text { EIA, WB, PCR } \\
\text { FC, Cytogenetic }\end{array}$ & $\begin{array}{l}\text { HTLV-1+, four with p16 } \\
\text { deletion, one with p53 mutation }\end{array}$ & 8 cases of pediatric ATLL patients \\
\hline Brazil [329] & CSS & EIA WB, Nested PCR & HTLV-1+ found in 48 ATLL. & 188 patients with a T-cell disorder. 53 ATLL. Rio de Janeiro, Brazil \\
\hline Brazil [330] & Cohort & $\begin{array}{l}\text { EIA, PA, WB, } \\
\text { Sequencing }\end{array}$ & HTLV- $1+$ found in 11 cases. & 14 cases of ATLL, Rio de Janeiro. \\
\hline Brazil [331] & Case report & EIA & HTLV-1+ & Hodgkin-like ATLL from Salvador, Bahía. \\
\hline Brazil [332] & Case report & EIA & HTLV-1+ & ATLL from Brasilia. \\
\hline Brazil [333] & Case report & EIA & HTLV-1+ & ATLL with Hyalohyphomycosis \\
\hline Brazil [334] & Case report & EIA & HTLV-2+ & Two HTLV-2+ ATLL cases in Maranhao, Northeast Brazil. \\
\hline Brazil [335] & Case report & EIA & HTLV-1+ & ATLL in a patient with Strongyloides stercoralis. \\
\hline
\end{tabular}


Table 4. Cont.

\begin{tabular}{|c|c|c|c|c|}
\hline $\begin{array}{c}\text { Country } \\
\text { (Ref) }\end{array}$ & Type of Study & Methods & $\begin{array}{l}\text { HTLV Association } \\
\text { (Main Finding) }\end{array}$ & Description of Study \\
\hline Brazil [336] & Case report & EIA & HTLV-1+ & IDH progressing to ATL. \\
\hline Brazil [337] & Case report & EIA & HTLV-1+ & Primary cutaneous type of ATLL. \\
\hline Brazil [338] & Case report & EIA & HTLV-1+ & 2 ATLL cases from Minas Gerais. \\
\hline Brazil [339] & Case report & EIA & HTLV-1+ & ATLL case. \\
\hline Brazil [340] & CSS & EIA, WB, PCR & $\begin{array}{c}\text { HTLV-1+ } \\
9 \% \text { also with HAM/TSP }\end{array}$ & 195 ATLL cases from Rio de Janeiro. \\
\hline Brazil [341] & CSS & EIA, PCR & HTLV-1+ & 28 ATLL from Bahía. \\
\hline
\end{tabular}


Zero to $0.39 \%$ HTLV positivity and no ATLL were found from Mexico [226,228,342,343]. Interestingly, in those studies in which subtypes were identified, HTLV-2 was the only or the most prevalent one [344-347]. In agreement, HTLV-2 was highly prevalent in IVDUs (22\%) [346]. From Central American countries, $5 \%$ HTLV-1 positivity has been found in the metropolitan areas of Panama City and Colon [229], and $0.24 \%$ and $0.68 \%$ HTLV-1 positive cases in Nicaragua and Costa Rica, respectively [235,348]. Honduras exhibited significant differences between regions, namely a $0.3-1.1 \%$ prevalence reported in the Central capital of Tegucigalpa and in the North West of the country, compared to a higher prevalence observed in coastal cities, particularly among black natives $(17.7 \%)$ and non-mestizos $(8.1 \%)[232,233,349]$. High prevalence of $8.3-9 \%$ has also been reported among indigenous populations of Panama, all carrying HTLV-2. Although multiple cases of TSP/HAM have been reported, mostly associated with HTLV-1 infection [349-353], only five ATLL cases have been reported in Central American countries, one associated with HTLV-1 infection and the others of an unknown etiology [230,231,234].

Screening for HTLV infection in blood banks is mandatory in several South American countries; Brazil has done it since 1993, Peru since 1998, Uruguay since 2000, Argentina since 2005, Chile since 2009 and Colombia since 2014. This has allowed for studies based on a large number of samples, and for a more factual estimation of HTLV prevalence. In Caracas, Venezuela a $0.2 \%$ HTLV positivity and a rate HTLV-1: HTLV-2 of 11:1 was observed [236]. Other similar studies also found low HTLV positivity in Maracay $(0.58 \%)$ and in Caracas $(1 \%)$, but higher in the Amazon region $(13 \%)[237,238]$. A study that included all Colombian departments found an overall seropositivity of $0.3 \%$, with most departments below $1 \%$ and Chocó being the only exception with $6.28 \%$ [239]. Similar studies from several blood banks from Medellin observed $0.06-0.176 \%$ positivity, mainly for HTLV-1 $[243,244]$. We also found two studies conducted on blood donors from Peru, Arequipa ( $0.9 \%$ HTLV-1 positive) and Abancay ( $3.4 \%$, unknown subtype), and one in pregnant women from Lima (1.7\% HTLV-1 positive) $[253,254,256]$. Concerning Chile, $0.12-0.24 \%$ HTLV positivity was described, showing higher prevalence in the central region of Valdivia than in Concepcion in the South; together with an almost 3:1 female to male ratio and a 7:1 HTLV-1 to HTLV-2 ratio [265,274]. A $0.13 \%$ HTLV positivity was found in Uruguay, ranging from $0.2 \%$ in the North to $0.09 \%$ in the South [277]. Those studies that were not based on archival data taken from blood donors reported an HTLV seropositivity of $0.42 \%$ in continental Ecuador, $1.57 \%$ in the Galapagos Island [252] and 2.4-3.5\% for Afro-descendants from the Esmeralda province [250,251], 4.3\% HTLV-1 in Bolivia [354] and 0\% HTLV positives [276] to 2.5\% HTLV-2 in Paraguay [355]. Figure 6 summarizes studies about the HTLV prevalence among LA countries.

Multiple studies have addressed HTLV prevalence in Brazil and Argentina revealing regions of high endemicity. In the former, the highest prevalence was demonstrated in the North-North East region, in particular in Salvador de Bahia, ranging from $0.046 \%$ to $1.8 \%$ [303,306,308-310,312,313,319,320,356-366], with slightly higher prevalence in specific villages with African characteristics, such as Piaui (2.24\%) [359], Taquarendi (3.85\%), Junco (1.23\%), Alegre (1.56\%) [363] and Marajó Island (1-2.06\%) [366]. In the South and South Eastern regions, HTLV prevalence ranged from $0.02 \%$ to $1.5 \%$ [302,303,305,318,321,322,358,367-370]. In urban Northern and Southern regions HTLV-1 prevailed over HTLV-2 [309,310,313,314,317,358]. The central region exhibited HTLV prevalence ranging from $0.02 \%$ to $1.6 \%[305,307,315-317,371-374]$, of which, for the Amazonian region, prevalence increased when indigenous villages were analyzed: $0.4-1.18 \%$ HTLV positivity in the city [375-378], whereas, in certain villages, the prevalence increased up to $13.88 \%$ [376,379-383]. In Argentina, most seroepidemiological studies were performed in the North and central regions, and an HTLV-1 endemic area was discovered in Jujuy, a North Western province. HTLV prevalence in central provinces ranged from $0 \%$ to $0.2 \%(0.028-0.26 \%$ HTLV- $1 ; 0.007-0.03 \%$ HTLV-2) [281,282,284,285,287-292,294-296,384]. In contrast, this incidence is increased up to $9.8 \%$ of HTLV-1 in Jujuy [280,292,385,386], and to $31.5 \%$ when Jujuy family clusters were studied [387]. Surprisingly, other Northern Argentinean cities reported low HTLV positivity, namely $0.16-0.7 \%$ in Salta that borders with Jujuy [284,292], 0.6\% in Formosa [292] and 0.007\% in Misiones [295]. In the above-mentioned epidemiological studies, HTLV positivity seems enriched in populations with a high proportion of Amerindians, particularly for HTLV-2. Additionally, a higher prevalence of $17-19 \%$ was found among 
first generation Japanese immigrants, particularly those coming from the HTLV-1 endemic region of Kyushu $[354,388]$. Second and third generation Japanese-Bolivians were $6 \%$ HTLV-1 positive, closer to the native Bolivian population. HTLV prevalence has also been addressed in Japanese immigrants in Brazil $(1.8-6.8 \%)$ and their descendants $(0.73 \%)[361,389,390]$. See Table 5 for HTLV prevalence in other risk groups.

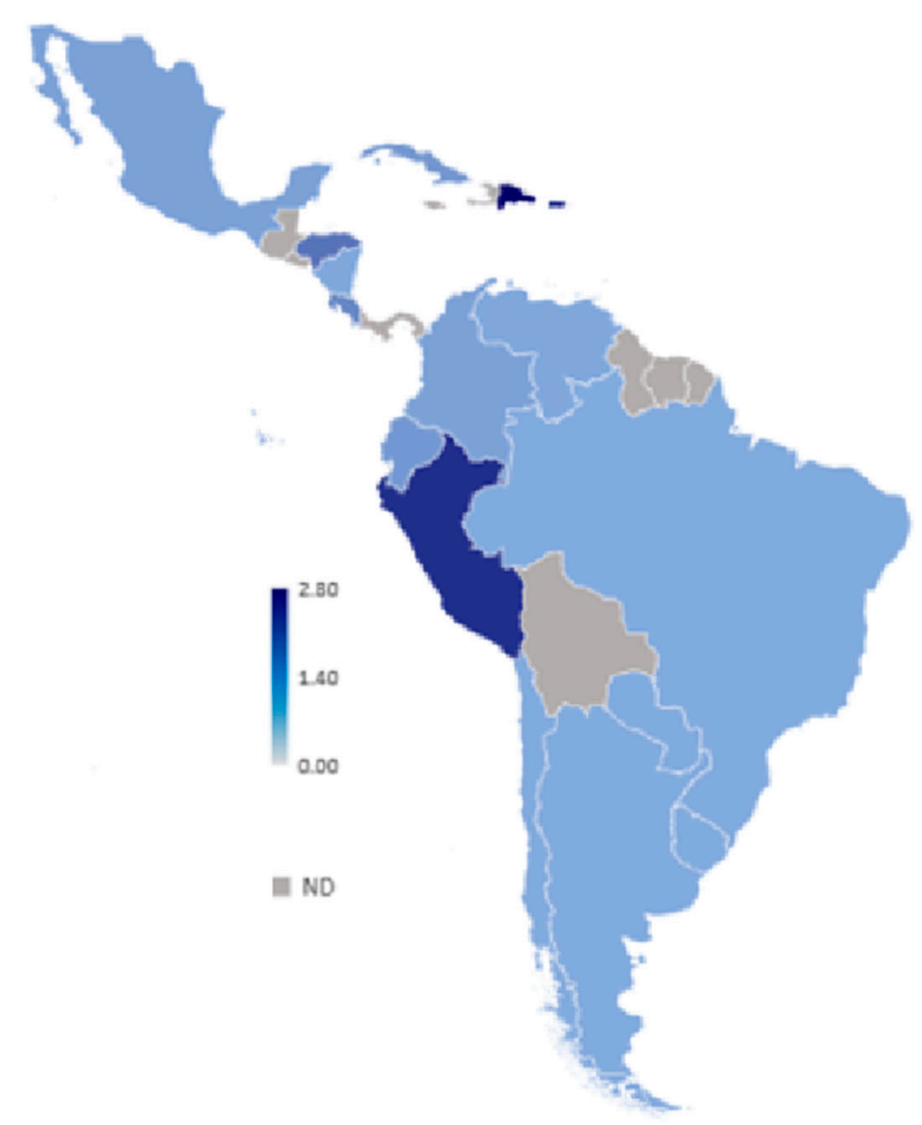

Figure 6. HTLV prevalence. Numeric values are in percentage. ND: not determined. 
Table 5. HTLV in risk groups.

\begin{tabular}{|c|c|c|c|c|c|c|c|c|}
\hline \multirow{2}{*}{ Country (Ref) } & \multicolumn{8}{|c|}{ HTLV Prevalence Risk Groups } \\
\hline & HIV+ & STD & FSW & MSM & Cervical Cancer & IVDU & Blood Transfusion & Close Contacts \\
\hline $\begin{array}{c}\text { Brazil [356,365, } \\
367,368,370,371, \\
373,376,391-408]\end{array}$ & $\begin{array}{c}1.1-16.3 \% \\
\mathrm{NT}=531 / 8154 \\
(6.5 \%) \\
n=96(\mathrm{H}-1) \\
n=69(\mathrm{H}-2)\end{array}$ & $\begin{array}{c}0.5 \% \\
\mathrm{NT}=2 / 395 \\
n=2(\mathrm{H}-1)\end{array}$ & $\begin{array}{c}1.4-3.2 \% \\
\mathrm{NT}=31 / 1336 \\
(2.3 \%) \\
n=30(\mathrm{H}-1) \\
n=1(\mathrm{H}-2)\end{array}$ & $\begin{array}{c}0.7-4.7 \% \\
\mathrm{NT}=38 / 1871 \\
\quad(2 \%) \\
n=9(\mathrm{H}-1)\end{array}$ & & $\begin{array}{c}11.7-35.2 \% \\
\mathrm{NT}=165 / 854 \\
(19.3 \%) \\
n=78(\mathrm{H}-1) \\
n=28(\mathrm{H}-2)\end{array}$ & $\begin{array}{c}7-10.2 \% \\
\mathrm{NT}=41 / 422 \\
(9.7 \%) \\
n=41(\mathrm{H}-1)\end{array}$ & $\begin{array}{c}21.2-35.1 \% \\
\mathrm{NT}=159 / 517 \\
(30.7 \%) \\
n=159(\mathrm{H}-1)\end{array}$ \\
\hline $\begin{array}{c}\text { Argentina } \\
{[387,409-418]}\end{array}$ & $\begin{array}{c}1.6-27.7 \% \\
\mathrm{NT}=114 / 1158(9.8 \%) \\
n=59(\mathrm{H}-1) \\
n=18(\mathrm{H}-2)\end{array}$ & $\begin{array}{c}1 \% \\
\mathrm{NT}=4 / 400\end{array}$ & $\begin{array}{c}1.5-1.6 \% \\
\mathrm{NT}=17 / 1069 \\
(1.6 \%) \\
n=6(\mathrm{H}-1) \\
n=1(\mathrm{H}-2)\end{array}$ & $\begin{array}{c}0.5-3 \% \\
\mathrm{NT}=26 / 1216 \\
(2.1 \%) \\
n=2(\mathrm{H}-1)\end{array}$ & & $\begin{array}{c}1.5-33.6 \% \\
\mathrm{NT}=149 / 1128 \\
(13.2 \%) \\
n=69(\mathrm{H}-1) \\
n=47(\mathrm{H}-2)\end{array}$ & & $\begin{array}{c}31.5 \% \\
\mathrm{NT}=29 / 92 \\
n=29(\mathrm{H}-1)\end{array}$ \\
\hline $\begin{array}{c}\text { Mexico } \\
\text { [228,343,344,346, } \\
\text { 347,419-422] }\end{array}$ & $\begin{array}{c}0-12.5 \% \\
\mathrm{NT}=31 / 642(4.8 \%) \\
n=4(\mathrm{H}-1) \\
n=24(\mathrm{H}-2)\end{array}$ & & $\begin{array}{c}0-1.8 \% \\
\mathrm{NT}=7 / 462 \\
(1.5 \%) \\
n=0(\mathrm{H}-1) \\
n=5(\mathrm{H}-2)\end{array}$ & $\begin{array}{c}0-0.9 \% \\
\mathrm{NT}=1 / 239 \\
(0.4 \%)\end{array}$ & $\begin{array}{c}1.4-6.5 \% \\
\text { NT }=9 / 195 \\
(4.6 \%)\end{array}$ & $\begin{array}{c}20.7 \% \\
\mathrm{NT}=106\end{array}$ & $\begin{array}{c}0-0.8 \% \\
\mathrm{NT}=3 / 834(0.36 \%)\end{array}$ & \\
\hline DR $[218,224]$ & $\begin{array}{c}5.5 \% \\
\mathrm{NT}=6 / 108\end{array}$ & $\begin{array}{c}2.8 \% \\
\mathrm{NT}=14 / 494\end{array}$ & $\begin{array}{c}4.2 \% \\
\mathrm{NT}=13 / 308\end{array}$ & & & $\begin{array}{c}2-14.3 \% \\
\mathrm{NT}=11 / 120 \\
(9.2 \%)\end{array}$ & & \\
\hline Cuba $[216,423]$ & $\begin{array}{c}0 \% \\
\mathrm{NT}=0 / 268\end{array}$ & $\begin{array}{c}1.7 \% \\
\mathrm{NT}=25 / 1444 \\
n=25(\mathrm{H}-1)\end{array}$ & & & & & $\begin{array}{c}10 \% \\
\mathrm{NT}=29 / 921 \\
n=29(\mathrm{H}-1)\end{array}$ & \\
\hline Venezuela [424] & & & $\begin{array}{c}0 \% \\
\mathrm{NT}=0 / 141\end{array}$ & $\begin{array}{c}\mathrm{1} \% \\
\mathrm{NT}=1 / 100 n=1 \\
(\mathrm{H}-1)\end{array}$ & & & & \\
\hline Ecuador [252] & & $\begin{array}{c}0.6 \% \\
\mathrm{NT}=1 / 159 \\
n=1(\mathrm{H}-1)\end{array}$ & $\begin{array}{c}1.4 \% \\
\mathrm{NT}=2 / 141 \\
n=2(\mathrm{H}-1)\end{array}$ & & & & & \\
\hline CR [348] & & & & & $\begin{array}{c}0.7 \% \\
\mathrm{NT}=3 / 436 \\
n=3(\mathrm{H}-1)\end{array}$ & & & \\
\hline Colombia [241] & & & & & & $\begin{array}{c}7.8 \% \\
\mathrm{NT}=13 / 167 \\
n=13(\mathrm{H}-1)\end{array}$ & & \\
\hline Peru [425] & & & $\begin{array}{c}9.5 \% \\
\mathrm{NT}=184 / 1938 \\
n=184(\mathrm{H}-1)\end{array}$ & & & & & \\
\hline
\end{tabular}

Prevalence of HTLV infection in specific risk groups, the range of positives and the value of the number of positives/total of tested individuals (NT) are given as percentages. Data based on one single study does not include a range. When the study addressed the HTLV type, the number of positives $(n)$ found for HTLV-1 (H-1) or HTLV-2 (H-2) are also given. FSW: female sex workers, STD: sexually transmitted diseases, MSM: men that have sex with men, IVDU: intravenous drug users. 
While the most pathogenic HTLV-1 strain is more prevalent among urban mestizo, Afro-descendants and Caucasian populations, HTLV-2 seems to be more prevalent among some Amerindian tribes. Interestingly, different endemic zones for HTLV-1 and HTLV-2 infections have been described among different tribes of Colombian Amerindians [426-429], with a general higher HTLV-1 prevalence in tribes from the Andes and other highlands than in lowlands, and vice versa for HTLV-2. Likewise, the Peruvian Andeans such as the Quechua exhibit 2.8-5.1\% HTLV-1 positivity and 0\% HTLV-2 [430,431]. The exceptions of Amazonian communities with an almost exclusive HTLV-1 infection are the Shipibo-Konibo (1.9\%), the Wayku (2.5\%) and San Francisco (1.4\%) [432,433]. In Chile, higher prevalence was also found in Amerindian tribes than in mestizo urban populations, with those from the highland Atacama region exhibiting the highest positivity with $6.5 \%$, while Mapuches were $0.7-1 \%$, Huilliches were $1.9 \%$ and natives from the island of Chiloe and Pitrufquen town in the South of Chile were 1.5\% [434-436]. Additionally, in those studies in which the viral strain has been addressed, an almost exclusive presence of HTLV-1 was found [434,436]. HTLV-1 infection among Bolivian Amerindians was 5.3\% in the Aimara and 4.5\% in the Quechua [437]. Other Amerindian populations outside the high endemicity region of the Amazonia, such as Guaranies, Kayapo and Kraho tribes, showed HTLV prevalence of $5.7 \%, 33.3 \%$ and $12.2 \%$, respectively [438,439]. It is worth mentioning that, while the HTLV-1 prevalence was below 11\% in endemic regions, HTLV-2 prevalence was significantly higher [428,429]. An international study that analyzed Indians from Colombia, Venezuela, Bolivia, Brazil, Paraguay and Chile found HTLV-2 positivity of up to 57.9\% in the Kayapo, Brazil, $34.8 \%$ in Alacalf, Chile and $16.4 \%$ in the Chaco, Paraguay [437]. Higher HTLV-2 positivity has also been demonstrated for Amerindians populations from Argentina, such as the Toba (10-36.4\%), Gran Chaco (22\%), Mataco (3\%) and Mapuches (2\%) [284,290,385-387,412,437,440-443]. Other Amerindians that exhibited an almost exclusive HTLV-2 prevalence were those from the Gran Chaco region of Paraguay (4-44\%) [355,442], Boca Colorado (4.54\%) and Galilea (2.38\%) in Peru [443] and the Yaruro/Guahibo (24.8-61\%) and the Pume (5\%) in Venezuela [444-446]. Of note, ethnic groups with $0 \%$ positivity to both types have been described in Venezuela, Colombia, Ecuador and Bolivia [251,426,437]. Figure 4 maps the prevalence of HTLV-1 and HTLV-2 among the Amerindian populations.

There are multiple reports of ATLL in South America, mostly describing a disease with similar features to Japan ATLL, but in younger individuals. In Colombia, $19 \mathrm{HTLV}$ positive ATLL cases have been reported, 12 confirmed as HTLV-1, while, in the others, the HTLV subtype was not investigated [246-249]. On the other hand, about 200 of TSP/HAM cases have been documented, with half of them confirmed to be in HTLV infected individuals [249,447-451]. It is also notable that many cases come from the Tumaco district, in which TSP/HAM was originally described and in which a 5.3\% HTLV-1 positivity has been reported among adults [241]. Furthermore, 12 ATLL cases from Peru and an additional case of a Peruvian immigrant in Uruguay were described, all of them being fatal [257-259,261-263,279]. These ATLLs displayed common features, since half of them had gastrointestinal tract compromise, and half of them occurred in individuals younger than $50 \mathrm{yr}$, including a $20 \mathrm{yr}$ female. There were also seven DLBCL developing in HTLV-1 seropositive patients, but in which, the presence of the provirus was not assessed [260]. The tumor cell also harbored EBV in three of these DLBCLs. As an HTLV endemic country, Peru reports large cohorts of TSP/HAM reflecting a common disease [452-455], and also cases in which HTLV infection correlates with infective dermatitis [456], including children in which neurological disorders co-exists with infective dermatitis [457] and Strongyloides stercoralis [458,459]. Fifty-four cases of ATLL have been reported from Chile [266-272,275]. Highlights are the early presentation, with medians of 50 yrs and 51 yrs for the largest cohorts [266,268], and an onset concomitant with or proceeded by TSP/HAM. It is also interesting to point out that all reported cases in large cohorts are of Caucasian origin (49/49) [266,268,270]. Barrientos A, et al. found HTLV positivity by PCR in 16/88 (18.2\%) cases of hematological malignancies (15 HTLV-1 and 1 HTLV-2), including two of myeloid origin. The median age of diagnosis was 33 yrs (2-92 yrs), with 50\% of HTLV positive patients being 30 yrs or younger. No ATLL assignation was given in this study [273]. Multiple cases of TSP/HAM are also reported from Chile [460-463], but, contrary to ATLL, TSP/HAM occurs in 
Caucasians, in mestizo and Chilean Amerindians. There were no reports of other HTLV-associated diseases. In Argentina, ATLL cases have been described in the highly endemic Jujuy, with five cases with confirmed diagnoses [298]. There are seven other ATLL cases reported (two originating in brothers) [300,301]. In addition, TSP/HAM cases have been described in Aymara Amerindians, also in Jujuy [464], and also in Caucasian patients from other non-endemic regions [465-468]. Figure 7 shows an example of an ATLL with a CD4+CD25+FOXP3+ regulatory T cell phenotype.

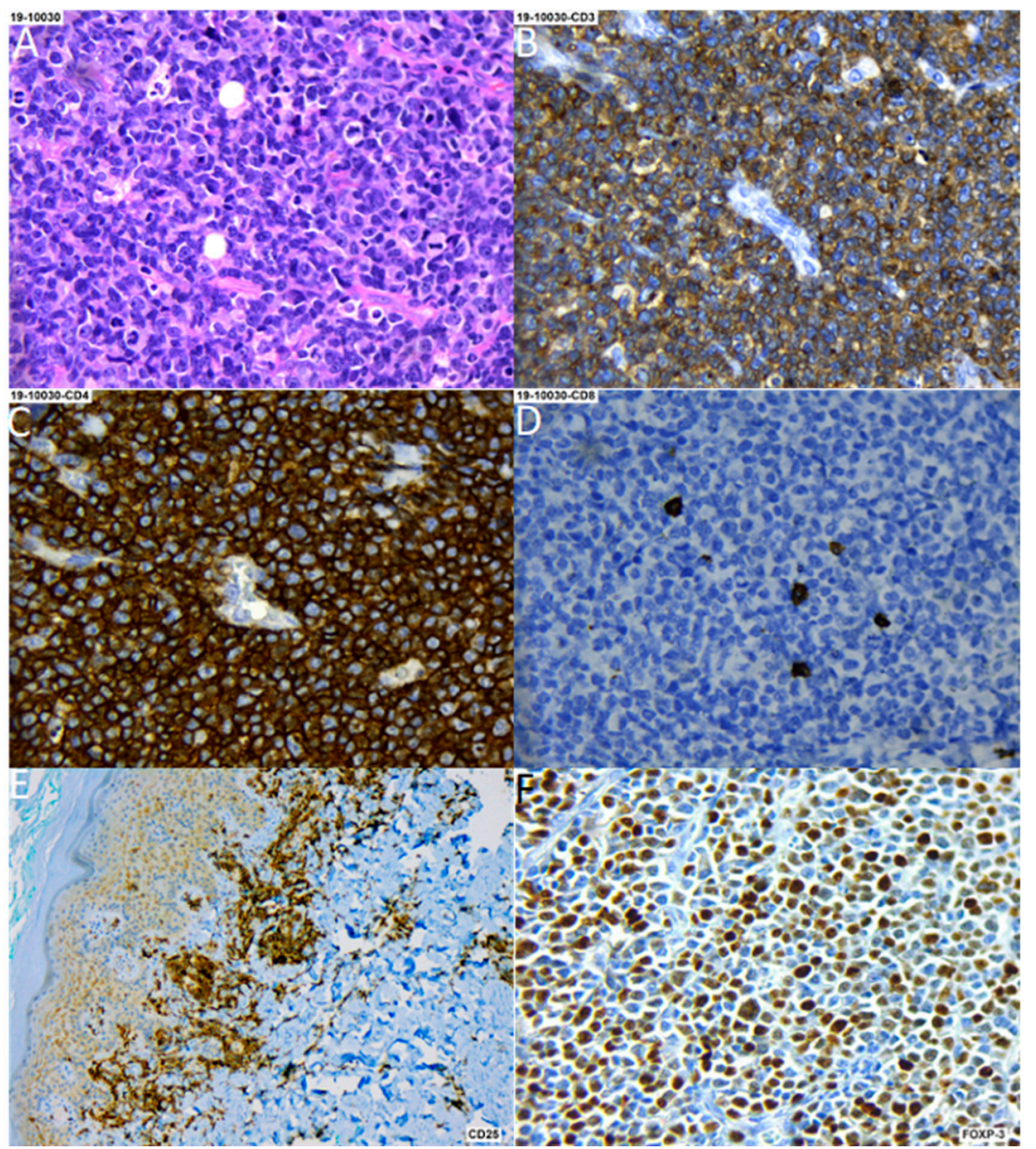

Figure 7. Adult T cell lymphoma (ATLL) of CD4 T cells. (A) Hematoxylin-Eosin staining. (B) CD3 staining. (C) CD4 staining. (D) CD8 staining. (E) CD25 staining. (F) FOXP3 staining. Magnification A, B, C, D and F 40x, E 10×.

The number of ATLL and TSP/HAM cases reported from Brazil is in agreement with a country of high HTLV endemicity. For instance, ATLL cases have been reported in the urban areas of North East Brazil, by and large in the Bahía state that presents the largest prevalence of HTLV-1 infection [326,327,333,335,336,469-471]. Characteristics of these ATLL are that they displayed cutaneous involvement [323,324], or were associated with infective dermatitis (IDH) [336], hyalohyphomycosis [333], Strongyloides stercoralis [335] or Hodgkin-like features [332]. Remarkably, ATLL has also been described in 31 pediatric patients [472]. In the South of Brazil, most reports are from Rio de Janeiro, where ATLL features often included a primary cutaneous type presentation [330,340,394,406], 9\% (of 195 patients) co-presented with TSP/HAM [340], and eight cases were in pediatric patients [328]. There are at least 27 articles describing TSP/HAM cases that also support a common disease. TSP/HAM incidence was increased in HTLV-1 and HIV positive individuals (18-30\%) versus those who were only HTLV positive $(1.93 \%)$ [473,474], and pediatric cases of TSP/HAM have also been reported [472]. HTLV infection was also associated with IDH [475] and other dermatologic [476-480], oral [481], ocular [482] and neurologic [483] complications. 
Although there are multiple reports of TSP/HAM from Venezuela, Ecuador, Uruguay and Paraguay, we could not find a single report of ATLL in these countries.

HTLV-1A has been found throughout South America [282,304,484-487]. On the other hand, Amerindians with high HTLV-2 prevalence almost exclusively carry the HTLV-2B genotype [442,445,446,488,489]. HTLV-2B was also the prevalent genotype in Mexico [345,420] and Panama [490], while HTLV-2A [491] and -2C [492] have been found in Brazilian Amerindians co-infected with HIV, and HTLV-2A in healthy Kayapo Amerindians [493]. This is important because, although published studies support a relative high incidence of ATLL in South American countries, the disease seems most prevalent among mestizo and Caucasian populations than among Amerindians, despite their higher HTLV-2 positivity.

\section{Discussion}

The association between EBV infection and lymphoma varies worldwide. The most compelling observation is the higher incidence of EBV-positive cHL in LA than in industrialized countries, and also the relationship between the age at which EBV primo-infection occurs and the onset of cHL. In underdeveloped and developing LA populations, earlier exposure to EBV in the face of a relatively underdeveloped immune response might be a predisposing factor for EBV-positive cHL. Socioeconomic improvement in Brazil turned into a decreased incidence from $87 \%$ to $46 \%$ in a 54 year period [32]. A similar picture emerges for EBV-positive BL, since this disease shows features of endemic BL in particularly underdeveloped regions, for instance, $76-100 \%$ in North Brazil [36,56], while it resembles more the sporadic form in the South of Brazil, Chile and Argentina [114]. Fewer driver mutations, especially among genes with roles in apoptosis, were demonstrated in EBV-positive BL from USA and Uganda, suggesting a specific BL phenotype, irrespective of geographic origin [494]. Particular pathogenic mechanisms may predispose against EBV-positive cHL and EBV-positive BL, such as ethnicity, endemic infectious agents, low age of seroconversion or differences in socioeconomic development.

EBV-associated T and NK LPDs represent a broad spectrum of diseases that occurs with higher incidence in Asian and LA populations. The incidence of these lymphomas in LA should grant EBV1 and EBV2 prevalence studies, particularly for Mexico and Peru, in which this lymphoma is highly prevalent. NKT LPDs often emerge within CAEBV disease in which infection of T- or NK- cells apparently occurred during primary infection. Genetic alterations are rare in CAEBV, but mutations in DDX3X, KMT2D, BCOR, BCORL1, TET2 and KM6A have been identified [495]. Likewise, LA has shown slightly higher EBV association frequencies in DLBCL, particularly in Peru. Peru has also reported cases of systemic EBV-positive T-cell lymphoma of childhood [99]. Gene expression profiling shows that EBV-positive DLBCL NOS, is molecularly distinct from EBV-negative DLBCL in Western developed populations, with NFKB p50, STAT-3 and CD30 more commonly expressed in EBV-positive DLBCLs [496]. No genetic study has been conducted in DLBCL of Hispanic patients so far.

ENKTL represents around 23\% of all T-cell lymphomas in LA (up to $40 \%$ in Mexico and $66 \%$ in Guatemala), compared with $4 \%$ to $5 \%$ in Europe and the United States. The clinical presentation is similar in all geographic regions; however, patients in LA tend to present with more advanced clinical stages [497]. In the ENKTCL arising in East Asia, genetic analyses have shown that activating mutations of the JAK-STAT pathway, such as in JAK3 (5-35\%), STAT3 (6-27\%) and STAT5B (2-6\%) genes are characteristic of this lymphoma [498,499]. Other mutations include the RNA helicase DDX3X, the tumor suppressor gene TP53, as well as genes encoding proteins involved in epigenetic pathways (MLL2, ASXL3, ARID1A and EP300) [134]. In a study of 71 ENKTCL cases from three different centers in LA (42 from Mexico, 17 from Peru and 12 from Argentina), mutations affecting the JAK-STAT signaling pathway were identified in $27 \%$ of cases, being STAT3 the most frequently mutated gene (22\%). Mutations in BCOR, DDX3X and TP53 were also identified, but with different frequencies than in Asian cohorts [500]. These data indicate that ENKTCL shows a similar mutational landscape in LA and Asia.

With respect to KSHV, available reports based on healthy populations and risk groups make it possible to infer an LA prevalence higher than in the US and non-Mediterranean Europe but lower than endemic regions of Africa and the Mediterranean. With the exception of Chile, LA exhibits global 
frequencies above 3\%, and particularly above 10\% for Cuba, Colombia, Argentina (San Salvador Jujuy), Ecuadorian Afro-descendants and Peru. Indeed, large KS series (e.g., $\geq 50$ cases) from Cuba, Colombia and Peru have been published [184,501,502], including a series of cases of cKS published before the HIV/AIDS era, and of pediatric KS [503]. KS has also been documented as the third most common neoplasm in Peru [504].

In Amerindian tribes in which the KSHV genotype E is endemic, viral transmission starts very early, with 35 to $65 \%$ seropositives by age 10 [150,196,197,505], supporting casual contacts between family members as an important via of viral dissemination. Indeed, close contacts of KS patients have higher KSHV prevalence than the general population (Table 3). A similar scenario is found for HTLV, with seroprevalences increasing with age [442,506]. A study of 104 mothers with TSP/HAM showed that $19-31 \%$ of their children were already HTLV seropositive [454], supporting an early mechanism of vertical transmission, such as breast feeding, which could explain the pediatric presentation of ATLL and TSP/HAM in LA HTLV endemic zones. On the contrary, among non-endemic populations, the high prevalence among MSM and FSW supports sexual transmission as an important route for KSHV dissemination (Table 5). However, the latter is not as clear for HTLV infection, since those studies based on people attending STD clinics (0.6-2.8\%), FSW (below 5\% in most studies) and MSM (2\% and below) reported lower frequencies than those observed for KSHV. An important exception is HTLV transmission among IVDUs that is consistently high (7.8-20.7\%) in LA countries, with a notable higher prevalence of HTLV-2, and also in blood transfused individuals (0.4-10\%), supporting contaminated blood as an important source for viral transmission. It is worth mentioning a study from Venezuela, in which three of five organ recipients from an HTLV-1 positive multi-donor became seropositive [507].

While ATLL among Amerindians is very rare, TSP/HAM is commonly reported. TSP/HAM was first described in the Southern Pacific of Colombia in 1981 as a chronic non-hereditary spastic paraparesis, initially termed Pacific spastic paraparesis [508], later also observed in the Caribbean islands of Martinique and Jamaica and in HTLV endemic regions of Japan. TSP/HAM seems to be highly prevalent in LA, particularly for Afro-descendants, but also for mestizo and Caucasian populations [223,249,351,448,449,452-455,461,464,472,509]. Likewise, infective dermatitis, strongyloidiasis and many other dermatological, oral, ocular and neurological complications are usually found co-presenting with ATLL or TSP/HAM, or independent of those diseases in HTLV endemic regions of Peru, Chile and Brazil. Infective dermatitis and strongyloidiasis sometimes precede TSP/HAM or ATLL $[248,325,456]$. It is also worth mentioning that extensive series of pediatric TSP/HAM have been reported from Salvador de Bahia and Rio de Janeiro in Brazil and in Peru [457,472]. All these studies pointed out that South America represents a major endemic area for HTLV infection and associated diseases. Remarkably, Mexico did not report HTLV positive ATLL or TSP/HAM.

Reports of ATLL series were found only for Brazil and Chile (see Table 4), which makes it difficult to identify the unique features of the disease presentation in our population. Furthermore, most case reports lack molecular and serological methods to confirm HTLV infection. Nevertheless, during the review process those cases in which the neoplasm co-presented with TSP/HAM, infective dermatitis or strongyloidiasis, or with the characteristic flower cell, were assumed to be bona fide ATLL. However, absence of confirmatory tests may miss early ATLL, for instance, in the smoldering stage, in which there is no significant lymphocytosis. Still, there do not seem to be major clinical differences between the ATLL cases in LA and those from Japan, or from other parts of the world [340]. Perhaps the most distinctive feature is an early presentation. Iwanaga et al. reported that in Brazil the median age of presentation is $44 \mathrm{yrs}$, while in Japan it is $68 \mathrm{yrs}$ [510], and, in spite of being named as an adult disease, there are pediatric cases of ATLL in Brazil [323,325,328,340,471]. The Chilean ATLL cohort also had a younger disease presentation than Japan, with a median age of 50 yrs [266]. Most studies also support a poor prognosis for ATLL, the study of 195 cases from Brazil found an overall survival of 9.2 months [340]. 


\section{Conclusions}

We observed a high incidence of EBV-positive lymphomas of T/NK cell origin for Mexico and Peru and of BL for North Brazil. Peru also carries the highest frequency of EBV-positive HL and DLBCL than any other LA country. The presentation of HL and BL was also earlier than for industrialized countries, coinciding with an early EBV primo-infection, in spite of there being no evidence of infectious mononucleosis in the region. High prevalence of KSHV and HTLV was found among Amerindian populations, with different distributions between low-land (e.g., the Amazons) and high-land (e.g., the Andes) tribes. In spite of this, there were only scarce reports of MCD, PEL and ATLL. However, Peru reports KS as its third most common neoplasm.

Author Contributions: Conceptualization, P.C. and E.M.F.-P.; methodology, P.C., D.L. and R.H.; formal analysis, P.C., D.L. and R.H.; investigation, P.C., D.L., R.H., S.M.R.P., F.V.G., I.R., F.H.G., S.M.R., C.B., A.M.S., V.S., E.D.M., M.V.P. and E.M.F.-P.; resources, E.D.M., S.M.R.P., I.R., S.M.R. and C.B.; data curation, P.C., D.L., R.H., S.M.R.P., F.V.G., I.R., F.H.G., S.M.R., C.B., A.M.S., V.S., E.D.M., M.V.P. and E.M.F.-P.; writing-original draft preparation, P.C. and E.M.F.-P.; writing-review and editing, D.L., R.H., S.M.R.P., F.V.G., I.R., F.H.G., S.M.R., C.B., A.M.S., V.S., E.D.M. and M.V.P.; supervision, M.V.P. and E.M.F.-P.; project administration, M.V.P. and E.M.F.-P.; funding acquisition, M.V.P. and E.M.F.-P. All authors have read and agreed to the published version of the manuscript.

Funding: This study was supported in part by CYTED: RIAL 217RT0523.

Acknowledgments: PACh, EDM and MVP are members of the National Research Council (CONICET) Research Career Program. We would like to thank the "RED-IBEROAMERICANA para el desarrollo de una plataforma para el estudio de Linfomas" (RIAL-CYTED-217RT0523) from CYTED.

Conflicts of Interest: The authors declare no conflict of interest.

\section{Abbreviations}

AIDS: acquired immune deficiency syndrome; ATLL, adult T cell leukemia/lymphoma; BL, Burkitt lymphoma; CAEBV, chronic active EBV infection; CD, Castleman disease; DLBCL, diffuse large B-cell lymphoma; EBV, Epstein-Barr virus; ENKTCL, extranodal NK/T-cell lymphoma, nasal type; FSW, female sex worker; HAART, highly active antiretroviral therapy; HIV, human immunodeficiency virus; HL, Hodgkin lymphoma, of mix cellularity (HL-MC), of nodular sclerosis (HL-NS), of lymphocyte depleted (HL-ND), of classic type (cHL); HTLV-1 or -2 , human T cell lymphotropic virus type 1 or type 2 ; HVL-LPD, hydroa vacciniforme-like lymphoproliferative disorder; IARC, International Agency for Research on Cancer; IM, infectious mononucleosis; IDH, infective dermatitis; IVDU, intravenous drug user, KS, Kaposi sarcoma; KSHV, Kaposi sarcoma herpesvirus; LA, Latin America; LPD, lymphoproliferative disorder; MCD, multicentric Castleman disease; MSM, men that have sex with men; NHL, non-Hodgkin lymphoma; NOS, not otherwise specified; PBL, plasmablastic lymphoma; PEL, primary effusion lymphoma; PTLD, post-trasplant lymphoproliferative disorder; RIAL-CYTED, Ibero American network for the study of lymphomas; TSP/HAM, tropical spastic paraparesis / HTLV-1-associated myelopathy; UCD, unicentric Castleman disease; WHO, World Health Organization; YRS, years.

\section{References}

1. Schottenfeld, D.; Beebe-Dimmer, J. The cancer burden attributable to biologic agents. Ann Epidemiol. 2015, 25, 183-187. [CrossRef]

2. Morales-Sanchez, A.; Fuentes-Panana, E.M. Human viruses and cancer. Viruses 2014, 6, 4047-4079. [CrossRef] [PubMed]

3. Biological Agents. IARC Monographs on the Evaluation of Carcinogenic Risks to Humans; 100B (Eipstein Barr Virus); Internactional Agency for Research on Cancer: Lyon, France, 2012; pp. 49-92.

4. Casulo, C.; Friedberg, J.W. Burkitt lymphoma- a rare but challenging lymphoma. Best Pract. Res. Clin. Haematol. 2018, 31, 279-284. [CrossRef] [PubMed]

5. Shannon-Lowe, C.; Rickinson, A.B.; Bell, A.I. Epstein-Barr virus-associated lymphomas. Philos. Trans. R. Soc. Lond. B Biol. Sci. 2017, 372, e20160271. [CrossRef] [PubMed]

6. Higgins, C.D.; Swerdlow, A.J.; Macsween, K.F.; Harrison, N.; Williams, H.; McAulay, K.; Thomas, R.; Reid, S.; Conacher, M.; Britton, K.; et al. A study of risk factors for acquisition of Epstein-Barr virus and its subtypes. J. Infect. Dis. 2007, 195, 474-482. [CrossRef] [PubMed]

7. Odumade, O.A.; Hogquist, K.A.; Balfour, H.H., Jr. Progress and problems in understanding and managing primary Epstein-Barr virus infections. Clin. Microbiol. Rev. 2011, 24, 193-209. [CrossRef] 
8. Hsu, J.L.; Glaser, S.L. Epstein-barr virus-associated malignancies: Epidemiologic patterns and etiologic implications. Crit. Rev. Oncol. Hematol. 2000, 34, 27-53. [CrossRef]

9. WHO Classification of Tumours of Hematopoietic and Lymphoid Tissues, 4th ed.; International Agency for Research on Cancer: Lyon, France, 2017; Volume 2.

10. Cohen, M.; De Matteo, E.; Narbaitz, M.; Carreno, F.A.; Preciado, M.V.; Chabay, P.A. Epstein-Barr virus presence in pediatric diffuse large B-cell lymphoma reveals a particular association and latency patterns: Analysis of viral role in tumor microenvironment. Int. J. Cancer 2013, 132, 1572-1580. [CrossRef]

11. Cohen, M.; Narbaitz, M.; Metrebian, F.; De Matteo, E.; Preciado, M.V. Epstein-Barr virus-positive diffuse large B-cell lymphoma association is not only restricted to elderly patients. Int. J. Cancer 2014, 135, 2816-2824. [CrossRef]

12. Cohen, M.; Vistarop, A.G.; Huaman, F.; Narbaitz, M.; Metrebian, F.; De Matteo, E.; Preciado, M.V.; Chabay, P.A. Cytotoxic response against Epstein Barr virus coexists with diffuse large B-cell lymphoma tolerogenic microenvironment: Clinical features and survival impact. Sci. Rep. 2017, 7, 1-10. [CrossRef]

13. Corti, M.; Minue, G.; Campitelli, A.; Narbaitz, M.; Gilardi, L. An Aggressive Plasmablastic Lymphoma of the Oral Cavity as Primary Manifestation of Acquired Immunodeficiency Syndrome: Case Report and Literature Review. Int. Arch. Otorhinolaryngol. 2015, 19, 354-358. [PubMed]

14. Lara, J.; Cohen, M.; De Matteo, E.; Aversa, L.; Preciado, M.V.; Chabay, P. Epstein-Barr virus (EBV) association and latency profile in pediatric Burkitt's lymphoma: Experience of a single institution in Argentina. J. Med. Virol. 2014, 86, 845-850. [CrossRef] [PubMed]

15. Corti, M.; Villafane, M.F.; Bistmans, A.; Campitelli, A.; Narbaitz, M.; Bare, P. Oral cavity and extra-oral plasmablastic lymphomas in AIDS patients: Report of five cases and review of the literature. Int. J. STD AIDS 2011, 22, 759-763. [CrossRef]

16. Chabay, P.; Lara, J.; Lorenzetti, M.; Cambra, P.; Acosta Haab, G.; Aversa, L.; De Matteo, E.; Preciado, M.V. Epstein Barr virus in relation to apoptosis markers and patients' outcome in pediatric B-cell non-Hodgkin lymphoma. Cancer Lett. 2011, 307, 221-226. [CrossRef]

17. Metta,H.; Corti, M.; Maranzana, A.; Schtirbu, R.; Narbaitz, M.; De Dios Soler, M. Unusual case of plasmablastic non-Hodgkin's lymphoma located in the liver. First case reported in an AIDS patient. Ann. Hepatol. 2009, 8, 242-245. [CrossRef]

18. Chabay, P.; De Matteo, E.; Lorenzetti, M.; Gutierrez, M.; Narbaitz, M.; Aversa, L.; Preciado, M.V. Vulvar plasmablastic lymphoma in a HIV-positive child: A novel extraoral localisation. J. Clin. Pathol. 2009, 62, 644-646. [CrossRef]

19. Chabay, P.; De Matteo, E.; Lorenzetti, M.; Barón, A.V.; Valva, P.; Preciado, M.V. Low frequency of Epstein Barr virus association and high frequency of p53 overexpression in an Argentinean pediatric T-cell lymphoma series. Pediatr. Dev. Pathol. 2009, 12, 28-34. [CrossRef]

20. Chabay, P.A.; Barros, M.H.; Hassan, R.; De Matteo, E.; Rey, G.; Carrico, M.K.; Renault, I.Z.; Preciado, M.V. Pediatric Hodgkin lymphoma in 2 South American series: A distinctive epidemiologic pattern and lack of association of Epstein-Barr virus with clinical outcome. J. Pediatr. Hematol. Oncol. 2008, 30, 285-291. [CrossRef]

21. Fellner, M.D.; Durand, K.; Correa, R.M.; Redini, L.; Yampolsky, C.; Colobraro, A.; Sevlever, G.; Teyssié, A.R.; Benetucci, J.; Picconi, M.A. Circulating Epstein-Barr virus (EBV) in HIV-infected patients and its relation with primary brain lymphoma. Int. J. Infect. Dis. 2007, 11, 172-178. [CrossRef]

22. De Matteo, E.; Baron, A.V.; Chabay, P.; Porta, J.; Dragosky, M.; Preciado, M.V. Comparison of Epstein-Barr virus presence in Hodgkin lymphoma in pediatric versus adult Argentine patients. Arch. Pathol. Lab. Med. 2003, 127, 1325-1329.

23. Preciado, M.V.; Fallo, A.; Chabay, P.; Calcagno, L.; De Matteo, E. Epstein Barr virus-associated lymphoma in HIV-infected children. Pathol Res. Pract. 2002, 198, 327-332. [CrossRef] [PubMed]

24. Rao, C.R.; Gutierrez, M.I.; Bhatia, K.; Fend, F.; Franklin, J.; Appaji, L.; Gallo, G.; O'Conor, G.; Lalitha, N.; Magrath, I. Association of Burkitt's lymphoma with the Epstein-Barr virus in two developing countries. Leuk. Lymphoma 2000, 39, 329-337. [CrossRef] [PubMed]

25. Preciado, M.V.; Cristobal, E.; Menarguez, J.; Martinez Montero, J.C.; Diez, B.; De Matteo, E.; Grinstein, S. Oncogene expression in tumour cells of pediatric Hodgkin's disease in Argentina-Correlation with Epstein Barr virus presence. Pathol. Res. Pract. 1998, 194, 25-31. [CrossRef]

26. Preciado, M.V.; De Matteo, E.; Diez, B.; Grinstein, S. Epstein-Barr virus (EBV) latent membrane protein (LMP) in tumor cells of Hodgkin's disease in pediatric patients. Med. Pediatr. Oncol. 1995, 24, 1-5. [CrossRef] 
27. Preciado, M.V.; De Matteo, E.; Diez, B.; Menarguez, J.; Grinstein, S. Presence of Epstein-Barr virus and strain type assignment in Argentine childhood Hodgkin's disease. Blood 1995, 86, 3922-3929. [CrossRef]

28. Drut, R.M.; Day, S.; Drut, R.; Meisner, L. Demonstration of Epstein-Barr viral DNA in paraffin-embedded tissues of Burkitt's lymphoma from Argentina using the polymerase chain reaction and in situ hybridization. Pediatr. Pathol. 1994, 14, 101-109. [CrossRef]

29. Poles, W.A.; Nishi, E.E.; de Oliveira, M.B.; Eugenio, A.I.P.; de Andrade, T.A.; Campos, A.; de Campos, R.R., Jr.; Vassallo, J.; Alves, A.C.; Scapulatempo Neto, C.; et al. Targeting the polarization of tumor-associated macrophages and modulating mir-155 expression might be a new approach to treat diffuse large B-cell lymphoma of the elderly. Cancer Immunol. Immunother. 2019, 68, 269-282. [CrossRef]

30. Guedes, J.C.R.; Cunha, K.; Machado, J.; Pinto, L.W. Nasal-type extranodal T-cell/NK lymphoma in association with hemophagocytic syndrome. An. Bras. Dermatol. 2018, 93, 422-425. [CrossRef]

31. Miranda, M.F.R.; Santos, J.; Muller, S.F.R.; Bittencourt, M.J.S.; Brito, A.C.; Barros Junior, J.; Xerfan, E.M.S. Hydroa Vacciniforme-Like T-Cell Lymphoma: A Further Brazilian Case. Am. J. Dermatopathol. 2018, 40, 201-204. [CrossRef]

32. Campos, A.; Moreira, A.; Ribeiro, K.B.; Paes, R.P.; Zerbini, M.C.; Aldred, V.; de Souza, C.A.; Neto, C.S.; Soares, F.A.; Vassallo, J. Frequency of EBV associated classical Hodgkin lymphoma decreases over a 54-year period in a Brazilian population. Sci. Rep. 2018, 8, 1-8. [CrossRef]

33. Barros, M.H.; Leite, E.; Chabay, P.; Morais, V.; Stefanoff, G.; Hassan, R. Diagnosing lymphoma in a setting with a high burden of infection: A pediatric case of Epstein-Barr virus-associated aggressive B-cell lymphoma with t(8;14) (q23;q32) and extensive necrosis mimicking tuberculosis. Rev. Soc. Bras. Med. Trop. 2015, 48, 108-111. [CrossRef] [PubMed]

34. Andrade, T.A.; Evangelista, A.F.; Campos, A.H.; Poles, W.A.; Borges, N.M.; Camillo, C.M.; Soares, F.A.; Vassallo, J.; Paes, R.P.; Zerbini, M.C.; et al. A microRNA signature profile in $\mathrm{EBV}^{+}$diffuse large B-cell lymphoma of the elderly. Oncotarget 2014, 5, 11813-11826. [CrossRef] [PubMed]

35. Ferreira, C.R.; Felipe-Silva, A.; de Campos, F.P.F.; Zerbini, M.C.N. Nodal Epstein-Barr virus-positive T-cell/NK-cell lymphoma associated with immunodeficiency: A rare condition looking for recognition. Autops. Case Rep. 2014, 4, 25-34. [CrossRef] [PubMed]

36. Rebelo-Pontes, H.A.; Abreu, M.C.; Guimarães, D.M.; Fonseca, F.P.; Andrade, B.A.; Almeida, O.P.; Pinto Júnior, D.D.; Corrêa-Pontes, F.S. Burkitt's lymphoma of the jaws in the Amazon region of Brazil. Med. Oral Patol. Oral Cir. Bucal 2014, 19, e32-e37. [CrossRef] [PubMed]

37. Minnicelli, C.; Barros, M.H.; Klumb, C.E.; Romano, S.O.; Zalcberg, I.R.; Hassan, R. Relationship of Epstein-Barr virus and interleukin 10 promoter polymorphisms with the risk and clinical outcome of childhood Burkitt lymphoma. PLoS ONE 2012, 7, e46005. [CrossRef]

38. Assis, M.C.; Campos, A.H.; Oliveira, J.S.; Soares, F.A.; Silva, J.M.; Silva, P.B.; Penna, A.D.; Souza, E.M.; Baiocchi, O.C. Increased expression of $\mathrm{CD}^{+} \mathrm{CD} 25^{+} \mathrm{FOXP} 3^{+}$regulatory $\mathrm{T}$ cells correlates with Epstein-Barr virus and has no impact on survival in patients with classical Hodgkin lymphoma in Brazil. Med. Oncol. 2012, 29, 3614-3619. [CrossRef]

39. Santos, M.; Nogueira, L.; Talahri, C.; Massone, C.; Cerroni, L.; Mira, M.T.; Talhari, S. Hydroa vacciniforme-like lymphoma in a patient from the Brazilian Amazon. Int. J. Dermatol. 2013, 52, 641-643. [CrossRef]

40. Marques, M.; Luz, E.; Hummel, M.; Vieira, M.; Bahia, R.C.; Oliveira, M.C.; Netto, E.M.; Luz, I.; Araujo, I. Prognostic Biomarkers and EBV Infection Research in Diffuse Large B-Cell Lymphoma of the Palatine Tonsils. ISRN Oncol. 2012, 2012, 7. [CrossRef]

41. Barros, M.H.; Hassan, R.; Niedobitek, G. Disease patterns in pediatric classical Hodgkin lymphoma: A report from a developing area in Brazil. Hematol. Oncol. 2011, 29, 190-195. [CrossRef]

42. Barros, M.H.; Scheliga, A.; De Matteo, E.; Minnicelli, C.; Soares, F.A.; Zalcberg, I.R.; Hassan, R. Cell cycle characteristics and Epstein-Barr virus are differentially associated with aggressive and non-aggressive subsets of Hodgkin lymphoma in pediatric patients. Leuk. Lymphoma 2010, 51, 1513-1522. [CrossRef]

43. Barros, M.H.; Vera-Lozada, G.; Soares, F.A.; Niedobitek, G.; Hassan, R. Tumor microenvironment composition in pediatric classical Hodgkin lymphoma is modulated by age and Epstein-Barr virus infection. Int. J. Cancer 2012, 131, 1142-1152. [CrossRef] [PubMed]

44. Souza, E.M.; Baiocchi, O.C.; Zanichelli, M.A.; Alves, A.C.; Assis, M.G.; Eiras, D.P.; Dobo, C.; Oliveira, J.S. Impact of Epstein-Barr virus in the clinical evolution of patients with classical Hodgkin's lymphoma in Brazil. Hematol. Oncol. 2010, 28, 137-141. [CrossRef] [PubMed] 
45. Souza, E.M.; Baiocchi, O.C.; Zanichelli, M.A.; Alves, A.C.; Assis, M.G.; Silva, J.M.; Dobo, C.; Oliveira, J.S. Matrix metalloproteinase-9 is consistently expressed in Hodgkin/Reed-Sternberg cells and has no impact on survival in patients with Epstein-Barr virus (EBV)-related and non-related Hodgkin lymphoma in Brazil. Med. Oncol. 2012, 29, 2148-2152. [CrossRef] [PubMed]

46. Gualco, G.; Domeny-Duarte, P.; Chioato, L.; Barber, G.; Natkunam, Y.; Bacchi, C.E. Clinicopathologic and molecular features of 122 Brazilian cases of nodal and extranodal NK/T-cell lymphoma, nasal type, with EBV subtyping analysis. Am. J. Surg. Pathol. 2011, 35, 1195-1203. [CrossRef]

47. Gaiolla, R.D.; Domingues, M.A.; Niero-Melo, L.; de Oliveira, D.E. Serum levels of interleukins 6, 10, and 13 before and after treatment of classic Hodgkin lymphoma. Arch. Pathol. Lab. Med. 2011, 135, 483-489.

48. Gualco, G.; Weiss, L.M.; Barber, G.N.; Bacchi, C.E. Diffuse large B-cell lymphoma involving the central nervous system. Int. J. Surg. Pathol. 2011, 19, 44-50. [CrossRef]

49. Gualco, G.; Ortega, V.; Chioato, L.; Musto, M.L.; Bacchi, L.M.; Weiss, L.M.; Bacchi, C.E. Hodgkin's Lymphoma Presenting as Dominant Gastric Lesion in Immunocompetent Patients: Report of 5 Cases With EBV Analysis. Int. J. Surg. Pathol. 2011, 19, 235-240. [CrossRef]

50. Machado, A.S.; Da Silva Robaina, M.C.; Magalhães De Rezende, L.M.; Apa, A.G.; Amoêdo, N.D.; Bacchi, C.E.; Klumb, C.E. Circulating cell-free and Epstein-Barr virus DNA in pediatric B-non-Hodgkin lymphomas. Leuk. Lymphoma 2010, 51, 1020-1027. [CrossRef]

51. Gualco, G.; Chioato, L.; Van Den Berg, A.; Weiss, L.M.; Bacchi, C.E. Composite lymphoma: EBV-positive classic Hodgkin lymphoma and peripheral T-cell lymphoma: A case report. Appl. Immunohistochem. Mol. Morphol. 2009, 17, 72-76. [CrossRef]

52. Campos, A.H.; Aldred, V.L.; Ribeiro, K.C.; Vassallo, J.; Soares, F.A. Role of immunoexpression of nitric oxide synthases by Hodgkin and Reed-Sternberg cells on apoptosis deregulation and on clinical outcome of classical Hodgkin lymphoma. Mol. Cell. Biochem. 2009, 321, 95-102. [CrossRef]

53. Queiroga, E.M.; Gualco, G.; Chioato, L.; Harrington, W.J.; Araujo, I.; Weiss, L.M.; Bacchi, C.E. Viral studies in burkitt lymphoma: Association with Epstein-Barr virus but not HHV-8. Am. J. Clin. Pathol. 2008, 130, 186-192. [CrossRef] [PubMed]

54. Queiroga, E.M.; Gualco, G.; Weiss, L.M.; Dittmer, D.P.; Araujo, I.; Klumb, C.E.; Harrington, W.J., Jr.; Bacchi, C.E. Burkitt lymphoma in Brazil is characterized by geographically distinct clinicopathologic features. Am. J. Clin. Pathol. 2008, 130, 946-956. [CrossRef] [PubMed]

55. Pizza, M.; Bruniera, P.; Luporini, S.M.; Marcelino da Silva, H.R.; Borsato, M.L.; de Castro, H.C.; Soares, F.A.; Paes, R.A. Detection of Epstein-Barr virus in children and adolescents with Burkitt's lymphoma by in situ hybridization using tissue microarrays. Hematology 2008, 13, 114-118. [CrossRef] [PubMed]

56. Hassan, R.; Klumb, C.E.; Felisbino, F.E.; Guiretti, D.M.; White, L.R.; Stefanoff, C.G.; Barros, M.H.; Seuanez, H.N.; Zalcberg, I.R. Clinical and demographic characteristics of Epstein-Barr virus-associated childhood Burkitt's lymphoma in Southeastern Brazil: Epidemiological insights from an intermediate risk region. Haematologica 2008, 93, 780-783. [CrossRef] [PubMed]

57. Ferrazzo, K.L.; Mesquita, R.A.; Aburad, A.T.; Nunes, F.D.; de Sousa, S.O. EBV detection in HIV-related oral plasmablastic lymphoma. Oral Dis. 2007, 13, 564-569. [CrossRef]

58. Figueiredo, C.P.; Franz-Vasconcelos, H.C.; Giunta, G.; Mazzuco, T.L.; Caon, T.; Fernandes, A.L.; Simoes, C.M.; Antunes, V.L.; Niel, C.; Barardi, C.R. Detection of Torque teno virus in Epstein-Barr virus positive and negative lymph nodes of patients with Hodgkin lymphoma. Leuk. Lymphoma 2007, 48, 731-735. [CrossRef]

59. Costa, H.; Franco, M.; Hahn, M.D. Primary lymphoma of the central nervous system: A clinical-pathological and immunohistochemical study of ten autopsy cases. Arq. Neuropsiquiatr. 2006, 64, 976-982. [CrossRef]

60. Musacchio, J.G.; Carvalho Mda, G.; Morais, J.C.; Silva, N.H.; Scheliga, A.; Romano, S.; Spector, N. Detection of free circulating Epstein-Barr virus DNA in plasma of patients with Hodgkin's disease. Sao Paulo Med. J. 2006, 124, 154-157. [CrossRef]

61. Araujo, I.; Bittencourt, A.L.; Barbosa, H.S.; Netto, E.M.; Mendonca, N.; Foss, H.D.; Hummel, M.; Stein, H. The high frequency of EBV infection in pediatric Hodgkin lymphoma is related to the classical type in Bahia, Brazil. Virchows Arch. 2006, 449, 315. [CrossRef]

62. Hassan, R.; White, L.R.; Stefanoff, C.G.; de Oliveira, D.E.; Felisbino, F.E.; Klumb, C.E.; Bacchi, C.E.; Seuanez, H.N.; Zalcberg, I.R. Epstein-Barr virus (EBV) detection and typing by PCR: A contribution to diagnostic screening of EBV-positive Burkitt's lymphoma. Diagn. Pathol. 2006, 1, 17. [CrossRef] 
63. Klumb, C.E.; Hassan, R.; De Oliveira, D.E.; De Resende, L.M.; Carrico, M.K.; De Almeida Dobbin, J.; Pombo-De-Oliveira, M.S.; Bacchi, C.E.; Maia, R.C. Geographic variation in Epstein-Barr virus-associated Burkitt's lymphoma in children from Brazil. Int. J. Cancer 2004, 108, 66-70. [CrossRef] [PubMed]

64. Klumb, C.E.; Hassan, R.; Zalcberg, I.R.; Resende, L.M.; Carrico, M.K.; Maia, R.C. p53 protein expression does not correlate with EBV status in childhood B non-Hodgkin lymphomas. Pediatr. Blood Cancer 2004, 43, 115-119. [CrossRef] [PubMed]

65. Pinto, M.T.; Ferreira, F.V.D.A.; Pitombeira, M.D.S.; Magalhães, S.M.M.; Costa, C.M.B.E.D.; Lima Filho, P.W.L.; Férrer, R.P.C.; Aguiar, A.L.P.D.; Rocha Filho, F.D. Analysis of the association between Epstein-Barr virus and classic Hodgkin s lymphoma in adult patients from Ceará (Brazil) by immunohistochemistry and in situ hybridization. J. Bras. Patol. Med. Lab. 2006, 42, 201-205. [CrossRef]

66. Spector, N.; Milito, C.B.; Biasoli, I.; Luiz, R.R.; Pulcheri, W.; Morais, J.C. The prognostic value of the expression of Bcl-2, p53 and LMP-1 in patients with Hodgkin's lymphoma. Leuk. Lymphoma 2005, 46, 1301-1306. [CrossRef] [PubMed]

67. Loureiro, M.M.; Morais, J.C.; Milito, C.B.; Portugal, R.D.; Pulcheri, W.; Spector, N. Expression of Epstein-Barr virus in patients with Hodgkin's disease: Report of 64 cases from Rio de Janeiro, Brazil. J. Bras. Patol. Med. Lab. 2004, 40, 37-40. [CrossRef]

68. Vassallo, J.; Metze, K.; Traina, F.; de Souza, C.A.; Lorand-Metze, I. Expression of Epstein-Barr virus in classical Hodgkin's lymphomas in Brazilian adult patients. Haematologica 2001, 86, 1227-1228.

69. Vassallo, J.; Metze, K.; Traina, F.; de Souza, C.A.; Lorand-Metze, I. The prognostic relevance of apoptosis-related proteins in classical Hodgkin's lymphomas. Leuk. Lymphoma 2003, 44, 483-488. [CrossRef]

70. Elgui de Oliveira, D.; Bacchi, M.M.; Abreu, E.S.; Niero-Melo, L.; Bacchi, C.E. Hodgkin disease in adult and juvenile groups from two different geographic regions in Brazil: Characterization of clinicopathologic aspects and relationship with Epstein-Barr virus infection. Am. J. Clin. Pathol. 2002, 118, 25-30. [CrossRef]

71. Altemani, A.; Barbosa, A.C.; Kulka, M.; Takahashi, T.; Endo, L.; Vassallo, J.; Lorand-Metze, I. Characteristics of nasal T/NK-cell lymphoma among Brazilians. Neoplasma 2002, 49, 55-60.

72. Sandlund, J.T.; Fonseca, T.; Leimig, T.; Verissimo, L.; Ribeiro, R.; Lira, V.; Berard, C.W.; Sixbey, J.; Crist, W.M.; Mao, L.; et al. Predominance and characteristics of Burkitt lymphoma among children with non-Hodgkin lymphoma in northeastern Brazil. Leukemia 1997, 11, 743-746. [CrossRef]

73. Razzouk, B.I.; Gan, Y.J.; Mendonca, C.; Jenkins, J.J.; Liu, Q.; Hudson, M.; Sixbey, J.W.; Ribeiro, R.C. Epstein-Barr virus in pediatric Hodgkin disease: Age and histiotype are more predictive than geographic region. Med. Pediatr. Oncol. 1997, 28, 248-254. [CrossRef]

74. Araujo, I.; Foss, H.D.; Bittencourt, A.; Hummel, M.; Demel, G.; Mendonca, N.; Herbst, H.; Stein, H. Expression of Epstein-Barr virus-gene products in Burkitt's lymphoma in Northeast Brazil. Blood 1996, 87, 5279-5286. [CrossRef] [PubMed]

75. Bacchi, M.M.; Bacchi, C.E.; Alvarenga, M.; Miranda, R.; Chen, Y.Y.; Weiss, L.M. Burkitt's lymphoma in Brazil: Strong association with Epstein-Barr virus. Mod. Pathol. 1996, 9, 63-67. [PubMed]

76. Armstrong, A.; Alexander, F.; Paes, R.P.; Morad, N.; Gallagher, A.; Krajewski, A.; Jones, D.; Angus, B.; Adams, J.; Cartwright, R. Association of Epstein-Barr virus with pediatric Hodgkin's disease. Am. J. Pathol. 1993, 142, 1683. [PubMed]

77. Quintanilla-Martinez, L.; Ridaura, C.; Nagl, F.; Saez-de-Ocariz, M.; Duran-McKinster, C.; Ruiz-Maldonado, R.; Alderete, G.; Grube, P.; Lome-Maldonado, C.; Bonzheim, I.; et al. Hydroa vacciniforme-like lymphoma: A chronic $\mathrm{EBV}^{+}$lymphoproliferative disorder with risk to develop a systemic lymphoma. Blood 2013, 122, 3101-3110. [CrossRef] [PubMed]

78. Palma, I.; Sanchez, A.E.; Jimenez-Hernandez, E.; Alvarez-Rodriguez, F.; Nava-Frias, M.; Valencia-Mayoral, P.; Salinas-Lara, C.; Velazquez-Guadarrama, N.; Portilla-Aguilar, J.; Pena, R.Y.; et al. Detection of Epstein-Barr virus and genotyping based on EBNA2 protein in Mexican patients with hodgkin lymphoma: A comparative study in children and adults. Clin. Lymphoma Myeloma Leuk. 2013, 13, 266-272. [CrossRef]

79. Garcéa-Álvarez, K.G.; Garibaldi-Covarrubias, R.; Flores-Márquez, M.R.; Ortiz-Hidalgo, C. Plasma cell myeloma associated with Epstein-Barr virus infection in an 11-year-old girl. Pediatr. Dev. Pathol. 2012, 15, 339-342. [CrossRef]

80. Aviles-Salas, A.; Herrera-Goepfert, R.; Aguilar-Leon, D.; Candelaria-Hernandez, M.; Martinez-Cordero, E.; Corti, M. Plasmablastic lymphoma of the gastrointestinal tract in AIDS patients. Medicina 2011, 71, 536-541. 
81. Hofscheier, A.; Ponciano, A.; Bonzheim, I.; Adam, P.; Lome-Maldonado, C.; Vela, T.; Cortes, E.; Ortiz-Hidalgo, C.; Fend, F.; Quintanilla-Martinez, L. Geographic variation in the prevalence of Epstein-Barr virus-positive diffuse large B-cell lymphoma of the elderly: A comparative analysis of a Mexican and a German population. Mod. Pathol. 2011, 24, 1046-1054. [CrossRef]

82. Dirnhofer, S.; Angeles-Angeles, A.; Ortiz-Hidalgo, C.; Reyes, E.; Gredler, E.; Krugmann, J.; Fend, F.; Quintanilla-Martinez, L. High prevalence of a 30-base pair deletion in the Epstein-Barr virus (EBV) latent membrane protein 1 gene and of strain type B EBV in Mexican classical Hodgkin's disease and reactive lymphoid tissue. Hum. Pathol. 1999, 30, 781-787. [CrossRef]

83. Elenitoba-Johnson, K.S.; Zarate-Osorno, A.; Meneses, A.; Krenacs, L.; Kingma, D.W.; Raffeld, M.; Jaffe, E.S. Cytotoxic granular protein expression, Epstein-Barr virus strain type, and latent membrane protein-1 oncogene deletions in nasal T-lymphocyte/natural killer cell lymphomas from Mexico. Mod. Pathol. 1998, 11, 754-761. [PubMed]

84. Magana, M.; Sangueza, P.; Gil-Beristain, J.; Sanchez-Sosa, S.; Salgado, A.; Ramon, G.; Sangueza, O.P. Angiocentric cutaneous T-cell lymphoma of childhood (hydroa-like lymphoma): A distinctive type of cutaneous T-cell lymphoma. J. Am. Acad. Dermatol. 1998, 38, 574-579. [CrossRef]

85. Quintanilla-Martinez, L.; Lome-Maldonado, C.; Schwarzmann, F.; Gredler, E.; Reyes, E.; Angeles-Angeles, A.; Fend, F. Post-transplantation lymphoproliferative disorders in Mexico: An aggressive clonal disease associated with Epstein-Barr virus type A. Mod. Pathol. 1998, 11, 200-208. [PubMed]

86. Quintanilla-Martínez, L.; Lome-Maldonado, C.; Ott, G.; Gschwendtner, A.; Gredler, E.; Reyes, E.; Angeles-Angeles, A.; Fend, F. Primary non-Hodgkin's lymphoma of the intestine: High prevalence of Epstein-Barr virus in Mexican lymphomas as compared with European cases. Blood J. Am. Soc. Hematol. 1997, 89, 644-651.

87. Quintanilla-Martinez, L.; Gamboa-Dominguez, A.; Gamez-Ledesma, I.; Orozco-Estevez, H.; Angeles-Angeles, A. High prevalence of the Epstein-Barr virus in a Mexican population with Hodgkin's disease. Rev. Investig. Clin. 1994, 46, 355-362.

88. Quintanilla-Martinez, L.; Gamboa-Domnquez, A.; Gamez-Ledesma, I.; Angeles-Angeles, A.; Mohar, A. Association of Epstein-Barr virus latent membrane protein and Hodgkin's disease in Mexico. Mod. Pathol. 1995, 8, 675-679.

89. Zarate-Osorno, A.; Roman, L.N.; Kingma, D.W.; Meneses-Garcia, A.; Jaffe, E.S. Hodgkin's disease in Mexico. Prevalence of Epstein-Barr virus sequences and correlations with histologic subtype. Cancer 1995, 75, 1360-1366. [CrossRef]

90. Cordova Perez, F.J.; Gonzalez-Keelan, C.I.; Velez, R. Epstein-Barr virus in biopsies from patients with Hodgkin and non-Hodgkin lymphoma at the University of Puerto Rico immunohistochemistry laboratory. $P$. R. Health Sci. J. 2003, 22, 125-129.

91. Aybar, A.; Krause, J.R. Coexpression of major histocompatibility complex class I and LMP1 in Epstein-Barr virus-positive Hodgkin's lymphoma in a pediatric age group. Microsc. Res. Tech. 2005, 68, 247-249. [CrossRef]

92. Riverend, E.; Rengifo, E.; Longchong, M.; Ruíz, R.; Tormo, B.; Garćia, J.; Portero, R.; Quintero, S.; Valdés, M.; Rodríguez, T.; et al. Burkitt's lymphoma in Cuba. I. Clinical and morphological features and EBV association. Oncology 1984, 41, 13-18. [CrossRef]

93. Quijano, S.; Saavedra, C.; Fiorentino, S.; Orozco, O.; Bravo, M.M. Epstein-Barr virus presence in Colombian Hodgkin lymphoma cases and its relation to treatment response. Biomedica 2004, 24, 163-173. [CrossRef] [PubMed]

94. Quijano, S.M.; Saavedra, C.; Bravo, M.M.; Fiorentino, S.; Orozco, O. Expression of heat shock proteins HSP72 and HSP73 in Colombian patients with Hodgkin lymphoma positive and negative for Epstein Barr virus. Rev. Med. Chile 2003, 131, 1375-1381. [CrossRef] [PubMed]

95. Beltran, B.E.; Quinones, P.; Morales, D.; Malaga, J.M.; Chavez, J.C.; Sotomayor, E.M.; Castillo, J.J. Response and survival benefit with chemoimmunotherapy in Epstein-Barr virus-positive diffuse large B-cell lymphoma. Hematol. Oncol. 2018, 36, 93-97. [CrossRef] [PubMed]

96. Aguilar, C.; Beltran, B.; Quiñones, P.; Carbajal, T.; Vilcapaza, J.; Yabar, A.; Segura, P.; Quintanilla-Martinez, L.; Miranda, R.N.; Castillo, J.J. Large B-cell lymphoma arising in cardiac myxoma or intracardiac fibrinous mass: A localized lymphoma usually associated with Epstein-Barr virus? Cardiovasc. Pathol. 2015, 24, 60-64. [CrossRef] 
97. Beltran, B.E.; Maza, I.; Moises-Alfaro, C.B.; Vasquez, L.; Quinones, P.; Morales, D.; Sanchez, G.; Paredes, G.; Oscanoa, M.; Geronimo, J.; et al. Thalidomide for the treatment of hydroa vacciniforme-like lymphoma: Report of four pediatric cases from Peru. Am. J. Hematol. 2014, 89, 1160-1161. [CrossRef]

98. Ernesto Beltran, B.; Quinones Avila, P.; Morales Luna, D.; Cotrina Montenegro, E.; Gallo Lopez, A.; Lopez Ilasaca, M. Gastrointestinal Epstein Barr virus positive diffuse large B cell lymphoma in elderly: Report of five cases and review of literature. Rev. Gastroenterol. Peru 2011, 31, 285-288.

99. Rodriguez-Pinilla, S.M.; Barrionuevo, C.; Garcia, J.; de los Angeles, M.; Pajares, R.; Casavilca, S.; Montes, J.; Martinez, A.; Montes-Moreno, S.; Sanchez, L.; et al. Epstein-Barr virus-positive systemic NK/T-cell lymphomas in children: Report of six cases. Histopathology 2011, 59, 1183-1193. [CrossRef]

100. Beltran, B.E.; Castillo, J.J.; Morales, D.; de Mendoza, F.H.; Quinones, P.; Miranda, R.N.; Gallo, A.; Lopez-Ilasaca, M.; Butera, J.N.; Sotomayor, E.M. EBV-positive diffuse large B-cell lymphoma of the elderly: A case series from Peru. Am. J. Hematol. 2011, 86, 663-667. [CrossRef]

101. Morales, D.; Beltran, B.; De Mendoza, F.H.; Riva, L.; Yabar, A.; Quinones, P.; Butera, J.N.; Castillo, J. Epstein-Barr virus as a prognostic factor in de novo nodal diffuse large B-cell lymphoma. Leuk. Lymphoma 2010, 51, 66-72. [CrossRef]

102. Beltran, B.; Salas, R.; Quiñones, P.; Morales, D.; Hurtado, F.; Cotrina, E.; Riva, L.; Castillo, J. EBV-positive diffuse large B-cell lymphoma in a human T-lymphotropic virus type 1 carrier. Infect. Agent. Cancer 2009, 4, 1-4. [CrossRef]

103. Rodriguez-Pinilla, S.M.; Barrionuevo, C.; Garcia, J.; Martinez, M.T.; Pajares, R.; Montes-Moreno, S.; Casavilca, S.; Montes, J.; Bravo, F.; Zaharia, M.; et al. EBV-associated cutaneous NK/T-cell lymphoma: Review of a series of 14 cases from peru in children and young adults. Am. J. Surg. Pathol. 2010, 34, 1773-1782. [CrossRef] [PubMed]

104. Barrionuevo, C.; Zaharia, M.; Martinez, M.T.; Taxa, L.; Misad, O.; Moscol, A.; Sarria, G.; Guerrero, I.; Casanova, L.; Flores, C.; et al. Extranodal NK/T-cell lymphoma, nasal type: Study of clinicopathologic and prognosis factors in a series of 78 cases from Peru. Appl. Immunohistochem. Mol. Morphol. 2007, 15, 38-44. [CrossRef] [PubMed]

105. Barrionuevo, C.; Anderson, V.M.; Zevallos-Giampietri, E.; Zaharia, M.; Misad, O.; Bravo, F.; Caceres, H.; Taxa, L.; Martinez, M.T.; Wachtel, A.; et al. Hydroa-like cutaneous T-cell lymphoma: A clinicopathologic and molecular genetic study of 16 pediatric cases from Peru. Appl. Immunohistochem. Mol. Morphol. 2002, 10, 7-14. [CrossRef] [PubMed]

106. Quintanilla-Martinez, L.; Franklin, J.L.; Guerrero, I.; Krenacs, L.; Naresh, K.N.; Rama-Rao, C.; Bhatia, K.; Raffeld, M.; Magrath, I.T. Histological and immunophenotypic profile of nasal NK/T cell lymphomas from Peru: High prevalence of p53 overexpression. Hum. Pathol. 1999, 30, 849-855. [CrossRef]

107. Arber, D.A.; Weiss, L.M.; Albújar, P.F.; Chen, Y.Y.; Jaffe, E.S. Nasal lymphomas in Peru. High incidence of T-cell immunophenotype and Epstein-Barr virus infection. Am. J. Surg. Pathol. 1993, 17, 392-399. [CrossRef]

108. Chang, K.L.; Albujar, P.F.; Chen, Y.Y.; Johnson, R.M.; Weiss, L.M. High prevalence of Epstein-Barr virus in the Reed-Sternberg cells of Hodgkin's disease occurring in Peru. Blood 1993, 81, 496-501. [CrossRef]

109. Montalvo, N.; Redroban, L. Hydroa Vacciniforme-Like EBV-Positive Cutaneous T-Cell Lymphoma, First Report of 2 Cases in Ecuador. Am. J. Dermatopathol. 2016, 38, e57-e59. [CrossRef]

110. Sánchez-Giler, S.; Herrera-Vásquez, A.; Castillo-Zambrano, C.; Solórzano-Alava, L.; Zambrano-Castro, D.; Kuon-Yeng, C.; Silva-Orellana, A.; Murillo-Zambrano, J.; Cucalón-González, G. Detección del Virus de Epstein-Barr en linfoma mediante qPCR//Detection of Epstein-Barr Virus (EBV) in lymphoma through qPCR. Ciencia Unemi 2018, 11, 126-133. [CrossRef]

111. Zoroquiain, P.; González, S.; Molgó, M.; Rodríguez, A.; Valbuena, J.R. Leukocytoclastic vasculitis as early manifestation of Epstein-Barr virus-positive diffuse large B-cell lymphoma of the elderly. Am. J. Dermatopathol. 2012, 34, 330-334. [CrossRef]

112. Martin, C.; Carrasco, C.; Sotomayor, C.; Otth, C. Prevalence of Epstein-Barr virus associated with nasal lymphoma in patients attending the regional hospital of Valdivia, Chile, between 1987 and 2005. J. Med. Virol. 2010, 82, 825-828. [CrossRef]

113. Cabrera, M.E.; Eizuru, Y.; Itoh, T.; Koriyama, C.; Tashiro, Y.; Ding, S.; Rey, S.; Akiba, S.; Corvalan, A. Nasal natural killer/T-cell lymphoma and its association with type "i"/Xhol loss strain Epstein-Barr virus in Chile. J. Clin. Pathol. 2007, 60, 656-660. [CrossRef] [PubMed] 
114. Gutierrez, M.I.; Bhatia, K.; Barriga, F.; Diez, B.; Muriel, F.S.; de Andreas, M.L.; Epelman, S.; Risueno, C.; Magrath, I.T. Molecular epidemiology of Burkitt's lymphoma from South America: Differences in breakpoint location and Epstein-Barr virus association from tumors in other world regions. Blood 1992, 79, 3261-3266. [CrossRef] [PubMed]

115. Ambinder, R.F.; Browning, P.J.; Lorenzana, I.; Leventhal, B.G.; Cosenza, H.; Mann, R.B.; MacMahon, E.M.; Medina, R.; Cardona, V.; Grufferman, S.; et al. Epstein-Barr virus and childhood Hodgkin's disease in Honduras and the United States. Blood 1993, 81, 462-467. [CrossRef] [PubMed]

116. Monterroso, V.; Zhou, Y.; Koo, S.; Glackin, C.; Bujan, W.; Medeiros, L.J. Hodgkin's disease in Costa Rica: A report of 40 cases analyzed for Epstein-Barr virus. Am. J. Clin. Pathol. 1998, 109, 618-624. [CrossRef]

117. Weinreb, M.; Day, P.J.; Niggli, F.; Powell, J.E.; Raafat, F.; Hesseling, P.B.; Schneider, J.W.; Hartley, P.S.; Tzortzatou-Stathopoulou, F.; Khalek, E.R.; et al. The role of Epstein-Barr virus in Hodgkin's disease from different geographical areas. Arch. Dis. Child. 1996, 74, 27-31. [CrossRef]

118. Gulley, M.L.; Eagan, P.A.; Quintanilla-Martinez, L.; Picado, A.L.; Smir, B.N.; Childs, C.; Dunn, C.D.; Craig, F.E.; Williams, J.W., Jr.; Banks, P.M. Epstein-Barr virus DNA is abundant and monoclonal in the Reed-Sternberg cells of Hodgkin's disease: Association with mixed cellularity subtype and Hispanic American ethnicity. Blood 1994, 83, 1595-1602. [CrossRef]

119. Takano, Y.; Colanzi, R.P.; Siga, J. High incidence of Epstein-Barr virus associated non-Hodgkin's lymphomas in the Bolivian mountains. Pathol. Int. 1994, 44, 237-240. [CrossRef]

120. Schwartz, E.J.; Molina-Kirsch, H.; Zhao, S.; Marinelli, R.J.; Warnke, R.A.; Natkunam, Y. Immunohistochemical characterization of nasal-type extranodal NK/T-cell lymphoma using a tissue microarray: An analysis of 84 cases. Am. J. Clin. Pathol. 2008, 130, 343-351. [CrossRef]

121. Grufferman, S.; Delzell, E. Epidemiology of Hodgkin's disease. Epidemiol. Rev. 1984, 6, 76-106. [CrossRef]

122. Howlader, N.N.A.; Krapcho, M.; Miller, D.; Brest, A.; Yu, M.; Ruhl, J.; Tatalovich, Z.; Mariotto, A.L.D.; Chen, H.S.; Feuer, E.J.; et al. SEER Cancer Statistics Review, 1975-2016; National Cancer Institute: Bethesda, MD, USA, 2016.

123. Macfarlane, G.J.; Evstifeeva, T.; Boyle, P.; Grufferman, S. International patterns in the occurrence of Hodgkin's disease in children and young adult males. Int. J. Cancer 1995, 61, 165-169. [CrossRef]

124. Kalisz, K.; Alessandrino, F.; Beck, R.; Smith, D.; Kikano, E.; Ramaiya, N.H.; Tirumani, S.H. An update on Burkitt lymphoma: A review of pathogenesis and multimodality imaging assessment of disease presentation, treatment response, and recurrence. Insights Imaging 2019, 10, 56. [CrossRef] [PubMed]

125. Crawford, D.H. Biology and disease associations of Epstein-Barr virus. Philos. Trans. R. Soc. Lond. B Biol. Sci. 2001, 356, 461-473. [CrossRef] [PubMed]

126. Ferreira, J.M.; Klumb, C.E.; de Souza Reis, R.; de Oliveira Santos, M.; Oliveira, J.F.; de Camargo, B.; Pombo-de-Oliveira, M.S. Lymphoma subtype incidence rates in children and adolescents: First report from Brazil. Cancer Epidemiol. 2012, 36, e221-e226. [CrossRef] [PubMed]

127. Chabay, P.A.; Preciado, M.V. EBV primary infection in childhood and its relation to B-cell lymphoma development: A mini-review from a developing region. Int. J. Cancer 2013, 133, 1286-1292. [CrossRef] [PubMed]

128. Pedraza, R.M.; Arboleda, L.P.A.; Sanchez-Romero, C.; Quinones, J.A.A.; Tovar, C.J.M.; Henao, J.R.; de Almeida, O.P. Intraoral EBV-positive sporadic Burkitt lymphoma in an elderly patient with bilateral presentation. Autops. Case Rep. 2019, 9, e2019117. [CrossRef]

129. Swerdlow, S.H.; Campo, E.; Harris, N.L.; Jaffe, E.S.; Pileri, S.A.; Stein, H.; Thiele, J. WHO Classification of Tumours of Haematopoietic and Lymphoid Tissues; IARC Press: Lyon, France, 2008.

130. Shimoyama, Y.; Yamamoto, K.; Asano, N.; Oyama, T.; Kinoshita, T.; Nakamura, S. Age-related Epstein-Barr virus-associated B-cell lymphoproliferative disorders: Special references to lymphomas surrounding this newly recognized clinicopathologic disease. Cancer Sci. 2008, 99, 1085-1091. [CrossRef]

131. Hoeller, S.; Tzankov, A.; Pileri, S.A.; Went, P.; Dirnhofer, S. Epstein-Barr virus-positive diffuse large B-cell lymphoma in elderly patients is rare in Western populations. Hum. Pathol. 2010, 41, 352-357. [CrossRef]

132. Beltran, B.; Morales, D.; Quiñones, P.; Salas, R.; Carrasco-Yalan, A.A. Distribution and Pathology Characteristics of Non Hodgkin Lymphoma in Peru: A Study of 1014 Cases Using WHO Classification of Lymphoid Neoplasm. Blood 2007, 110, 4419. [CrossRef]

133. Babcock, G.J.; Decker, L.L.; Volk, M.; Thorley-Lawson, D.A. EBV persistence in memory B cells in vivo. Immunity 1998, 9, 395-404. [CrossRef] 
134. Kim, W.Y.; Montes-Mojarro, I.A.; Fend, F.; Quintanilla-Martinez, L. Epstein-Barr Virus-Associated T and NK-Cell Lymphoproliferative Diseases. Front. Pediatr. 2019, 7, 71. [CrossRef]

135. Coleman, C.B.; Lang, J.; Sweet, L.A.; Smith, N.A.; Freed, B.M.; Pan, Z.; Haverkos, B.; Pelanda, R.; Rochford, R. Epstein-Barr Virus Type 2 Infects T Cells and Induces B Cell Lymphomagenesis in Humanized Mice. J. Virol. 2018, 92. [CrossRef] [PubMed]

136. Coleman, C.B.; Wohlford, E.M.; Smith, N.A.; King, C.A.; Ritchie, J.A.; Baresel, P.C.; Kimura, H.; Rochford, R. Epstein-Barr virus type 2 latently infects $\mathrm{T}$ cells, inducing an atypical activation characterized by expression of lymphotactic cytokines. J. Virol. 2015, 89, 2301-2312. [CrossRef] [PubMed]

137. Cohen, J.I.; Jaffe, E.S.; Dale, J.K.; Pittaluga, S.; Heslop, H.E.; Rooney, C.M.; Gottschalk, S.; Bollard, C.M.; Rao, V.K.; Marques, A.; et al. Characterization and treatment of chronic active Epstein-Barr virus disease: A 28-year experience in the United States. Blood 2011, 117, 5835-5849. [CrossRef] [PubMed]

138. Engels, E.A.; Pfeiffer, R.M.; Goedert, J.J.; Virgo, P.; McNeel, T.S.; Scoppa, S.M.; Biggar, R.J. Trends in cancer risk among people with AIDS in the United States 1980-2002. Aids 2006, 20, 1645-1654. [CrossRef] [PubMed]

139. Ferlay, J.; Colombet, M.; Soerjomataram, I.; Siegel, R.; Torre, L.; Jemal, A. Global and Regional Estimates of the Incidence and Mortality for 38 Cancers: GLOBOCAN 2018; World Health Organization, International Agency for Research on Cancer: Lyon, France, 2018.

140. Chadburn, A.; Said, J.; Gratzinger, D.; Chan, J.K.; de Jong, D.; Jaffe, E.S.; Natkunam, Y.; Goodlad, J.R. HHV8/KSHV-Positive Lymphoproliferative Disorders and the Spectrum of Plasmablastic and Plasma Cell Neoplasms: 2015 SH/EAHP Workshop Report-Part 3. Am. J. Clin. Pathol. 2017, 147, 171-187. [CrossRef] [PubMed]

141. Calabro, M.L.; Sarid, R. Human Herpesvirus 8 and Lymphoproliferative Disorders. Mediterr. J. Hematol. Infect. Dis. 2018, 10, e2018061. [CrossRef]

142. Kapelushnik, J.; Ariad, S.; Benharroch, D.; Landau, D.; Moser, A.; Delsol, G.; Brousset, P. Post renal transplantation human herpesvirus 8-associated lymphoproliferative disorder and Kaposi's sarcoma. Br. J. Haematol. 2001, 113, 425-428. [CrossRef]

143. Di Minno, G.; Perno, C.F.; Tiede, A.; Navarro, D.; Canaro, M.; Guertler, L.; Ironside, J.W. Current concepts in the prevention of pathogen transmission via blood/plasma-derived products for bleeding disorders. Blood Rev. 2016, 30, 35-48. [CrossRef]

144. Pellett, P.E.; Wright, D.J.; Engels, E.A.; Ablashi, D.V.; Dollard, S.C.; Forghani, B.; Glynn, S.A.; Goedert, J.J.; Jenkins, F.J.; Lee, T.H.; et al. Multicenter comparison of serologic assays and estimation of human herpesvirus 8 seroprevalence among US blood donors. Transfusion 2003, 43, 1260-1268. [CrossRef]

145. Ferreira, S.; Sanabani, S.; Reis, A.D.; Chamone, D.F.; Sabino, E.C. Human herpesvirus type 8 among Brazilian blood donors. Transfusion 2003, 43, 1764-1765. [CrossRef]

146. Perez, C.; Tous, M.; Gallego, S.; Zala, N.; Rabinovich, O.; Garbiero, S.; Martinez, M.J.; Cunha, A.M.; Camino, S.; Camara, A.; et al. Seroprevalence of human herpesvirus-8 in blood donors from different geographical regions of Argentina, Brazil, and Chile. J. Med. Virol. 2004, 72, 661-667. [CrossRef] [PubMed]

147. Zago, A.; Bourboulia, D.; Viana, M.C.; Collandre, H.; Dietze, R.; Boshoff, C.; Keller, R. Seroprevalence of human herpesvirus 8 and its association with Kaposi sarcoma in Brazil. Sex. Transm. Dis. 2000, 27, 468-472. [CrossRef] [PubMed]

148. Nascimento, M.C.; de Souza, V.A.; Sumita, L.M.; Freire, W.; Weiss, H.A.; Sabino, E.C.; Franceschi, S.; Pannuti, C.S.; Mayaud, P. Prevalence of, and risk factors for Kaposi's sarcoma-associated herpesvirus infection among blood donors in Brazil: A multi-center serosurvey. J. Med. Virol. 2008, 80, 1202-1210. [CrossRef] [PubMed]

149. Magri, M.C.; Carbone, P.H.; de los Santos-Fortuna, E.; Caterino-de-Araujo, A. A comparative study of the frequency of antibody and titers against human herpesvirus 8 latent and lytic antigens in "at-risk" individuals and among patients with Kaposi's sarcoma. J. Med. Virol. 2009, 81, 1292-1297. [CrossRef]

150. Nascimento, M.C.; Sumita, L.M.; Souza, V.U.; Weiss, H.A.; Oliveira, J.; Mascheretti, M.; Quiroga, M.; Vela, R.A.; Sabino, E.; Pannuti, C.S.; et al. Seroprevalence of Kaposi sarcoma-associated herpesvirus and other serologic markers in the Brazilian Amazon. Emerg. Infect. Dis. 2009, 15, 663-667. [CrossRef]

151. Avelleira, J.C.; Lupi, O.; Caterino-de-Araujo, A.; Santos-Fortuna Ede, L. Seroprevalence of HHV-8 infection in the pediatric population of two university hospitals in Rio de Janeiro, Brazil. Int. J. Dermatol. 2006, 45, 381-383. [CrossRef]

152. Chagas, C.A.; Endo, L.H.; Sakano, E.; Pinto, G.A.; Brousset, P.; Vassallo, J. Detection of herpesvirus type 8 (HHV8) in children's tonsils and adenoids by immunohistochemistry and in situ hybridization. Int. J. Pediatr. Otorhinolaryngol. 2006, 70, 65-72. [CrossRef] 
153. Freitas, R.B.; Freitas, M.R.; Linhares, A.C. Prevalence of human herpesvirus 8 antibodies in the population of Belém, Pará, Brazil. Rev. Inst. Med. Trop. São Paulo 2002, 44, 309-313. [CrossRef]

154. Colleoni, G.W.; Duarte, L.C.; Kerbauy, F.R.; Lobão, M.; Yunis, M.P.; Alves, A.C.; de Souza, V.A.; Bordin, J.O.; de Oliveira, J.S. 2-Chloro-deoxyadenosine induces durable complete remission in Castleman's disease but may accelerate its transformation to non-Hodgkin's lymphoma. Acta Oncol. 2003, 42, 784-787. [CrossRef]

155. Caroline Ribeiro Sales, A.; Romao de Souza Junior, V.; Iglis de Oliveira, M.; Azevedo Braga Albuquerque, C.; de Barros Campelo Junior, E.; Sergio Ramos de Araujo, P. Multicentric Castleman's disease in human immunodeficiency virus infection: Two case reports. J. Med. Case Rep. 2018, 12, 1-4. [CrossRef]

156. Naime Fde, F.; Fakhouri, F.; Martins, C.S.; Couto, W.J. HIV-associated multicentric Castleman's disease. Rare Tumors 2012, 4, 127-129. [CrossRef] [PubMed]

157. Pinto, L.W.; Nunes, E.P. Simultaneous lymph node involvement by Castleman disease and Kaposi sarcoma. Rev. Bras. Hematol. Hemoter. 2011, 33, 73-76. [PubMed]

158. Sousa, V.; Carvalho, L. Mediastinal angiofolicular lymphoid hyperplasia-Castleman's disease-Case report. Rev. Port. Pneumol. 2006, 12, 275-280. [CrossRef]

159. Tanaka, P.Y.; Atala, M.M.; Pereira, J.; Caterino-de-Araujo, A. Primary effusion lymphoma with cardiac involvement in HIV positive patient-complete response and long survival with chemotherapy and HAART. J. Clin. Virol. 2009, 44, 84-85. [CrossRef] [PubMed]

160. Cunha, A.; Costa, S.C.; Lima, C.S.; Ortega, M.; Costa, F.F. Low incidence of human herpesvirus 8 in bone marrow samples from Brazilian patients with multiple myeloma. Acta Haematol. 2001, 105, 247-248. [CrossRef] [PubMed]

161. Hulaniuk, M.L.; Torres, O.; Bartoli, S.; Fortuny, L.; Burgos Pratx, L.; Nunez, F.; Salamone, H.; Corach, D.; Trinks, J.; Caputo, M. Increased prevalence of human herpesvirus type 8 (HHV-8) genome among blood donors from North-Western Argentina. J. Med. Virol. 2017, 89, 518-527. [CrossRef]

162. Perez, C.L.; Tous, M.I.; Zala, N.; Camino, S. Human herpesvirus 8 in healthy blood donors, Argentina. Emerg. Infect. Dis. 2010, 16, 150-151. [CrossRef]

163. De Sanjose, S.; Mbisa, G.; Perez-Alvarez, S.; Benavente, Y.; Sukvirach, S.; Hieu, N.T.; Shin, H.R.; Anh, P.T.; Thomas, J.; Lazcano, E.; et al. Geographic variation in the prevalence of Kaposi sarcoma-associated herpesvirus and risk factors for transmission. J. Infect. Dis. 2009, 199, 1449-1456. [CrossRef]

164. Corti, M.; Villafañe, M.F.; Solari, R.; De Carolis, L.; Cangelosi, D.; Santoro, J.; Schtirbu, R.; Lewi, D.; Bistmans, A.; Narbaitz, M.; et al. Non-Hodgkin lymphomas of the oral cavity in AIDS patients in a reference hospital of infectious diseases in Argentina: Report of eleven cases and review of the literature. J. Gastrointest. Cancer 2011, 42, 143-148. [CrossRef]

165. Cacciari, V.; Arra, A.; D’Alessandro, D.; Errea, S.; Kohan, D.; Elsner, B.; Benetucci, J. Enfermedad de Castleman e infección por HIV. Presentación de dos casos y revisión de la literatura. Actual. Sida Infectol. 2015, 23, 32-40.

166. Perez, C.L.; Rudoy, S. Anti-CD20 monoclonal antibody treatment of human herpesvirus 8-associated, body cavity-based lymphoma with an unusual phenotype in a human immunodeficiency virus-negative patient. Clin. Diagn. Lab. Immunol. 2001, 8, 993-996. [CrossRef] [PubMed]

167. Perez, C.L.; Tous, M.I. Diversity of human herpesvirus 8 genotypes in patients with AIDS and non-AIDS associated Kaposi's sarcoma, Castleman's disease and primary effusion lymphoma in Argentina. J. Med. Virol. 2017, 89, 2020-2028. [CrossRef] [PubMed]

168. Mohanna, S.; Portillo, J.A.; Carriquiry, G.; Vidal, J.; Ferrufino, J.C.; Sanchez, J.; Bravo, F.; Gotuzzo, E. Human herpesvirus-8 in Peruvian blood donors: A population with hyperendemic disease? Clin. Infect. Dis. 2007, 44, 558-561. [CrossRef] [PubMed]

169. Mohanna, S.; Sanchez, J.; Ferrufino, J.C.; Bravo, F.; Gotuzzo, E. Characteristics of Castleman's disease in Peru. Eur. J. Intern. Med. 2006, 17, 170-174. [CrossRef]

170. Sevilla-Lizcano, D.B.; Frias-Soria, C.L.; Ortiz-Hidalgo, C. Castleman disease. Histopathological and immunohistochemical analysis of 39 cases. Gac. Med. Mex. 2017, 153, 550-558.

171. Sobrevilla-Calvo Pde, J.; Avilés-Salas, A.; Cortés-Padilla, D.E.; Rivas-Vera, S. Clinical and pathological features of Castleman's disease: Experience at the Instituto Nacional de Cancerología, Mexico City. Cir. Cir. 2009, 77, 187-192.

172. Sanchez-Pena, P.; Romero-Guadarrama, M.B.; Aguirre-Garcia, J. Diseases associated with HIV infection: Study of biopsies and surgical resection specimens at a large general hospital in Mexico City. Ann. Diagn. Pathol. 2009, 13, 162-167. [CrossRef] 
173. Avilés-Salas, A.; Candelaria, M.; Sevilla-Lizcano, D.B.; Burgos, S. Large B-cell lymphoma coexisting with Castleman's disease. Report of one case. Rev. Med. Chile 2017, 145, 945-949.

174. Avilés-Salas, A.; Cornejo-Juárez, P.; Sobrevilla-Calvo Pde, J. Coexistence of plasmablastic lymphoma, Kaposi sarcoma and Castleman disease in a patient with HIV infection. Rev. Chil. Infectol. 2011, 28, 76-80. [CrossRef]

175. Mayor, A.M.; Gómez, M.A.; Ríos-Olivares, E.; Hunter-Mellado, R.F. AIDS-defining neoplasm prevalence in a cohort of HIV-infected patients, before and after highly active antiretroviral therapy. Ethn. Dis. 2008, 18, S2-189-94.

176. Kouri, V.; Eng, S.M.; Rodriguez, M.E.; Resik, S.; Orraca, O.; Moore, P.S.; Chang, Y. Seroprevalence of Kaposi's sarcoma-associated herpesvirus in various populations in Cuba. Rev. Panam.Salud Pública 2004, 15, 320-325. [CrossRef] [PubMed]

177. Kouri, V.; Martinez, P.A.; Capo, V.; Blanco, O.; Rodriguez, M.E.; Jimenez, N.; Fleites, G.; Caballero, I.; Dovigny, M.C.; Aleman, Y.; et al. Kaposi's Sarcoma and Human Herpesvirus 8 in Cuba: Evidence of subtype B expansion. Virology 2012, 432, 361-369. [CrossRef] [PubMed]

178. Fernandez, L.; Serraino, D.; Rezza, G.; Lence, J.; Ortiz, R.M.; Cruz, T.; Vaccarella, S.; Sarmati, L.; Andreoni, M.; Franceschi, S. Infection with human herpesvirus type 8 and human T-cell leukaemia virus type 1 among individuals participating in a case-control study in Havana City, Cuba. Br. J. Cancer 2002, 87, 1253-1256. [CrossRef] [PubMed]

179. Rodríguez Silva, H.; Buchaca Faxas, E.; Machado Puerto, I.; Pérez Román, G.; Pérez Caballero, D. Castleman's disease. Review of five cases. Anal. Med. Interna 2005, 22, 24-27.

180. Orozco, B.; Gómez, L.M.; Estrada, S.; Restrepo, B.N.; Cataño, J.C. Relación entre el virus humano herpes 8 y el sarcoma de Kaposi en pacientes positivos y negativos para el VIH. Infectio 2011, 11, 111-116.

181. Guanira, J.V.; Casper, C.; Lama, J.R.; Morrow, R.; Montano, S.M.; Caballero, P.; Suarez, L.; Whittington, W.L.; Wald, A.; Sanchez, J.; et al. Prevalence and correlates of human herpesvirus 8 infection among Peruvian men who have sex with men. J. Acquir. Immune Defic. Syndr. 2008, 49, 557-562. [CrossRef]

182. Mohanna, S.; Maco, V.; Gown, A.; Morales, D.; Bravo, F.; Gotuzzo, E. Is classic Kaposi's sarcoma endemic in Peru?: Report of a case in an indigenous patient. Am. J. Trop. Med. Hyg. 2006, 75, 324-326. [CrossRef]

183. Revilla-Lopez, J.; Mendoza-Fabian, R.; Anampa-Guzman, A.; Rosales-Zuniga, J.; Chalco-Huaman, J. Endemic kaposi's sarcoma in a HIV-Negative patient. Rev. Peru. Med. Exp. Salud Publica 2015, 32, 808-812.

184. Mohanna, S.; Ferrufino, J.C.; Sanchez, J.; Bravo, F.; Gotuzzo, E. Epidemiological and clinical characteristics of classic Kaposi's sarcoma in Peru. J. Am. Acad. Dermatol. 2005, 53, 435-441. [CrossRef]

185. Jessurun, J.; Angeles-Angeles, A.; Gasman, N. Comparative demographic and autopsy findings in acquired immune deficiency syndrome in two Mexican populations. J. Acquir. Immune Defic. Syndr. 1990, 3, 579-583.

186. Ramirez-Amador, V.; Esquivel-Pedraza, L.; Sierra-Madero, J.; Anaya-Saavedra, G.; Gonzalez-Ramirez, I.; Ponce-de-Leon, S. The Changing Clinical Spectrum of Human Immunodeficiency Virus (HIV)-Related Oral Lesions in 1,000 Consecutive Patients: A 12-Year Study in a Referral Center in Mexico. Medicine 2003, 82, 39-50. [CrossRef] [PubMed]

187. Kourí, V.; Martínez, P.A.; Blanco, O.; Capó, V.; Rodríguez, M.E.; Dovigny Mdel, C.; Cardellá, L.; Gala, A.; Jiménez, N.A.; Luzardo, C.; et al. Kaposi's sarcoma-associated herpesvirus load in asymptomatic contacts of Cuban epidemic KS patients. Arch. Virol. 2010, 155, 1971-1976. [CrossRef] [PubMed]

188. Braz-Silva, P.H.; Tozetto-Mendoza, T.R.; Sumita, L.M.; Freire, W.; Palmieri, M.; do Canto, A.M.; Avelino-Silva, V.I.; Gallottini, M.; Mayaud, P.; Pannuti, C.S. Prospective study of human herpesvirus 8 oral shedding, viremia, and serological status among human immunodeficiency virus seropositive and seronegative individuals in Sao Paulo, Brazil. J. Oral Microbiol. 2017, 9, 1384287. [CrossRef] [PubMed]

189. De Oliveira Mendes Cahu, G.G.; Morais, V.M.; Lopes, T.R.; da Silva, D.M.; Tozetto-Mendoza, T.R.; Pannuti, C.S.; Cunha Duarte Coelho, M.R. Prevalence of human herpesvirus 8 infection in people living with HIV/AIDS in Pernambuco, Brazil. J. Med. Virol. 2016, 88, 2016-2020. [CrossRef] [PubMed]

190. Ishak Mde, O.; Martins, R.N.; Machado, P.R.; de Souza, L.L.; Machado, L.F.; Azevedo, V.N.; Katano, H.; Sata, T.; Hasegawa, H.; Vallinoto, A.C.; et al. High diversity of HHV-8 molecular subtypes in the Amazon region of Brazil: Evidence of an ancient human infection. J. Med. Virol. 2007, 79, 1537-1544. [CrossRef] [PubMed]

191. Machado, P.R.; Farias, K.J.; Pereira, M.G.; Freitas, P.P.; Fonseca, B.A. Human herpesvirus 8 (HHV-8) detected by nested polymerase chain reaction (PCR) in HIV patients with or without Kaposi's sarcoma. An analytic cross-sectional study. Sao Paulo Med. J. 2015, 134, 187-192. [CrossRef] 
192. Pierrotti, L.C.; Etzel, A.; Sumita, L.M.; Braga, P.E.; Eluf-Neto, J.; de Souza, V.A.; Segurado, A.A. Human herpesvirus 8 (HHV-8) infection in HIV/AIDS patients from Santos, Brazil: Seroprevalence and associated factors. Sex. Transm. Dis. 2005, 32, 57-63. [CrossRef]

193. Sosa, C.; Klaskala, W.; Chandran, B.; Soto, R.; Sieczkowski, L.; Wu, M.H.; Baum, M.; Wood, C. Human herpesvirus 8 as a potential sexually transmitted agent in Honduras. J. Infect. Dis. 1998, 178, 547-551. [CrossRef]

194. Sosa, C.; Benetucci, J.; Hanna, C.; Sieczkowski, L.; Deluchi, G.; Canizal, A.M.; Mantina, H.; Klaskala, W.; Baum, M.; Wood, C. Human herpesvirus 8 can be transmitted through blood in drug addicts. Medicina 2001, 61, 291-294.

195. Whitby, D.; Marshall, V.A.; Bagni, R.K.; Wang, C.D.; Gamache, C.J.; Guzman, J.R.; Kron, M.; Ebbesen, P.; Biggar, R.J. Genotypic characterization of Kaposi's sarcoma-associated herpesvirus in asymptomatic infected subjects from isolated populations. J. Gen. Virol. 2004, 85, 155-163. [CrossRef]

196. Cunha, A.M.; Caterino-de-Araujo, A.; Costa, S.C.; Santos-Fortuna, E.; Boa-Sorte, N.C.; Goncalves, M.S.; Costa, F.F.; Galvao-Castro, B. Increasing seroprevalence of human herpesvirus 8 (HHV-8) with age confirms HHV-8 endemicity in Amazon Amerindians from Brazil. J. Gen. Virol. 2005, 86, 2433-2437. [CrossRef] [PubMed]

197. De Souza, V.A.; Sumita, L.M.; Nascimento, M.C.; Oliveira, J.; Mascheretti, M.; Quiroga, M.; Freire, W.S.; Tateno, A.; Boulos, M.; Mayaud, P.; et al. Human herpesvirus-8 infection and oral shedding in Amerindian and non-Amerindian populations in the Brazilian Amazon region. J. Infect. Dis. 2007, 196, 844-852. [CrossRef] [PubMed]

198. Souza, V.A.; Salzano, F.M.; Petzl-Erler, M.L.; Nascimento, M.C.; Mayaud, P.; Borges, J.D.; Pannuti, C.S. Variations in human herpesvirus type 8 seroprevalence in Native Americans, South America. Emerg. Infect. Dis. 2010, 16, 1003-1006. [CrossRef] [PubMed]

199. Corti, M.; de Dios Soler, M.; Bare, P.; Villafañe, M.F.; de Tezanos Pinto, M.; Pérez Bianco, R.; Narbaitz, M. Linfomas asociados con la infección por el virus de la inmunodeficiencia humana: Subtipos histológicos y asociación con los virus de Epstein Barr y Herpes-8. Medicina 2010, 70, 151-158. [PubMed]

200. Hernàndez, D.E.; Masquelier, B.; Pèrez, O.; Oliver, M.; Fleury, H.J. Human herpesvirus 8 variants in Venezuelan patients with AIDS-related Kaposi sarcoma. Clin. Infect. Dis. 2003, 36, 385-386. [CrossRef] [PubMed]

201. Meng, Y.X.; Sata, T.; Stamey, F.R.; Voevodin, A.; Katano, H.; Koizumi, H.; Deleon, M.; De Cristofano, M.A.; Galimberti, R.; Pellett, P.E. Molecular characterization of strains of Human herpesvirus 8 from Japan, Argentina and Kuwait. J. Gen. Virol. 2001, 82, 499-506. [CrossRef]

202. Vassallo, J.; Rebouças, I.; Brousset, P. Detection of HHV-8 in reactive lymphoid tissue of patients from São Paulo state, Brazil. J. Clin. Pathol. 2002, 55, 78-79. [CrossRef]

203. Biggar, R.J.; Whitby, D.; Marshall, V.; Linhares, A.C.; Black, F. Human herpesvirus 8 in Brazilian Amerindians: A hyperendemic population with a new subtype. J. Infect. Dis. 2000, 181, 1562-1568. [CrossRef]

204. Cassar, O.; Blondot, M.L.; Mohanna, S.; Jouvion, G.; Bravo, F.; Maco, V.; Duprez, R.; Huerre, M.; Gotuzzo, E.; Gessain, A. Human herpesvirus 8 genotype E in patients with Kaposi sarcoma, Peru. Emerg. Infect. Dis. 2010, 16, 1459-1462. [CrossRef]

205. Kazanji, M.; Dussart, P.; Duprez, R.; Tortevoye, P.; Pouliquen, J.F.; Vandekerkhove, J.; Couppié, P.; Morvan, J.; Talarmin, A.; Gessain, A. Serological and molecular evidence that human herpesvirus 8 is endemic among Amerindians in French Guiana. J. Infect. Dis. 2005, 192, 1525-1529. [CrossRef]

206. Zong, J.; Ciufo, D.M.; Viscidi, R.; Alagiozoglou, L.; Tyring, S.; Rady, P.; Orenstein, J.; Boto, W.; Kalumbuja, H.; Romano, N.; et al. Genotypic analysis at multiple loci across Kaposi's sarcoma herpesvirus (KSHV) DNA molecules: Clustering patterns, novel variants and chimerism. J. Clin. Virol. 2002, 23, 119-148. [CrossRef]

207. Duong, Y.T.; Jia, H.; Lust, J.A.; Garcia, A.D.; Tiffany, A.J.; Heneine, W.; Switzer, W.M. Short communication: Absence of evidence of HTLV-3 and HTLV-4 in patients with large granular lymphocyte (LGL) leukemia. AIDS Res. Hum. Retrovir. 2008, 24, 1503-1505. [CrossRef] [PubMed]

208. Gessain, A.; Cassar, O. Epidemiological Aspects and World Distribution of HTLV-1 Infection. Front. Microbiol. 2012, 3, e00388. [CrossRef] [PubMed]

209. Lowis, G.W.; Sheremata, W.A.; Minagar, A. Epidemiologic features of HTLV-II: Serologic and molecular evidence. Ann. Epidemiol. 2002, 12, 46-66. [CrossRef]

210. Azran, I.; Schavinsky-Khrapunsky, Y.; Priel, E.; Huleihel, M.; Aboud, M. Implications of the evolution pattern of human T-cell leukemia retroviruses on their pathogenic virulence (Review). Int. J. Mol. Med. 2004, 14, 909-915. [CrossRef] [PubMed]

211. Verdonck, K.; González, E.; Van Dooren, S.; Vandamme, A.M.; Vanham, G.; Gotuzzo, E. Human T-lymphotropic virus 1: Recent knowledge about an ancient infection. Lancet Infect. Dis. 2007, 7, 266-281. [CrossRef] 
212. Blattner, W.A.; Kalyanaraman, V.S.; Robert-Guroff, M.; Lister, T.A.; Galton, D.A.; Sarin, P.S.; Crawford, M.H.; Catovsky, D.; Greaves, M.; Gallo, R.C. The human type-C retrovirus, HTLV, in Blacks from the Caribbean region, and relationship to adult T-cell leukemia/lymphoma. Int. J. Cancer 1982, 30, 257-264. [CrossRef]

213. Schüpbach, J.; Kalyanaraman, V.S.; Sarngadharan, M.G.; Blattner, W.A.; Gallo, R.C. Antibodies against three purified proteins of the human type $C$ retrovirus, human T-cell leukemia-lymphoma virus, in adult T-cell leukemia-lymphoma patients and healthy Blacks from the Caribbean. Cancer Res. 1983, 43, 886-891.

214. Hernandez Ramirez, P.; Rivero Jimenez, R.; Ballester Santovenia, M.; Navea Leyva, L.; Matutes, E.; Catovsky, D.; Yamaguchi, K.; Fukuyoshi, Y.; Nishimura, Y.; Kiyokawa, T.; et al. Very low seroprevalence of HTLV-I/II in Cuba: Antibodies in blood donors and in hematological and nonhematological patients. Vox Sang. 1991, 61, 277-278. [CrossRef]

215. Rasulee, A.; Le Riverend, E.; Shih, J.; Senjuta, N.; Pavlish, O.; Syrtsev, A.; Klepikov, N.; Lee, H.; Gurtsevitch, V. HTLV-I seroprevalence in blood donors in Cuba. Int. J. Cancer 1993, 54, 885-886. [CrossRef]

216. Silva Cabrera, E.; Perez Guevara, M.T.; Lubian Caballero, A.L.; de la Fuente Arzola, J.L.; Navea Leyva, L.; Cruz Sui, O. Search for antibodies against human T-cell lymphotropic virus type I (HTLV-I) in blood donors and risk groups. Rev. Cuba. Med. Trop. 1997, 49, 24-27.

217. Kaplan, J.E.; Yamamura, Y.; Rios-Olivares, E.O.; Cannon, R.O.; Khabbaz, R.F.; Gubler, D.J.; Kaiselburd, E.N.; Hartley, T.M.; Lairmore, M.D. Seroprevalence of human T lymphotropic virus type I in Puerto Rico. Am. J. Trop. Med. Hyg. 1989, 40, 659-662. [CrossRef] [PubMed]

218. Koenig, R.E.; Tolentino, M.; Taveras, L.; Ferro, F.; Zornoso, C.; Ferreiras, J.; Matos, G.; Oquist, C.; Capellan, M.; Amoros, C.; et al. Prevalence of HTLV infection in the Dominican Republic: Association with neurological disease. AIDS Res. Hum. Retrovir. 1992, 8, 221-226. [CrossRef] [PubMed]

219. Martinez-Diaz, H.; Frye-Maldonado, A.C.; Climent-Peris, C.; Velez-Rosario, R. Evaluation of serologic markers for transfusion transmitted infectious diseases for allogeneic blood donors in Puerto Rico. P. R. Health Sci. J. 1997, 16, 255-258. [PubMed]

220. Diaz Torres, H.M.; Alvarez Vega, N.; Munio Perurena, J.E.; Lubian Caballero, A.L.; Martin Alfonso, D.; Diaz Herrera, D.F.; Blanco de Armas, M. Human T-cell lymphotropic virus type I infection in patients with lymphoproliferative disorders at two sentinel sites in Cuba. Panam. Salud Pública 2010, 27, 17-22.

221. Estrada, R.A.; Luis, S.; Mustelier, R.; Ruiz, W.; Rodriguez, B.; Miranda, A.; Roman, G.C. Absence of human retroviral antibodies in epidemic neuropathy in Cuba: Report of the first two cases of HTLV-I-associated tropical spastic paraparesis observed in Cuba. J. Neurol. Sci. 1995, 128, 112-113. [CrossRef]

222. Reyes-Iglesias, Y.; Melendez-Feliciano, R.; Garayalde-Cotroneo, G. Presence of human T lymphotropic virus type I in two patients with progressive myelopathy in Puerto Rico. Neurology 1991, 41, 1515-1516. [CrossRef] [PubMed]

223. Vilchez, C.; Gonzalez-Reinoso, M.; Cubbison, C.; Perez-Then, E.; Roa, P.; Martinez, A.; Foerster, B.; Oviedo, J.; Stoeter, P. Atrophy, focal spinal cord lesions and alterations of diffusion tensor imaging (DTI) parameters in asymptomatic virus carriers and patients suffering from human T-lymphotrophic virus type 1 (HTLV-1)-associated myelopathy/tropical spastic paraparesis (HAM/TSP). J. Neurovirol. 2014, 20, 583-590.

224. Rodriguez, E.M.; de Moya, E.A.; Guerrero, E.; Monterroso, E.R.; Quinn, T.C.; Puello, E.; de Quiñones, M.R.; Thorington, B.; Glasner, P.D.; Zacarias, F.; et al. HIV-1 and HTLV-I in sexually transmitted disease clinics in the Dominican Republic. J. Acquir. Immune Defic. Syndr. 1993, 6, 313-318.

225. Rolo Gomez, F.; De Armas, M.B.; Mato Luis, J.; Lubian Caballero, A.L.; Diaz Torres, H. Confirmation of the presence in Cuba of human T-cell lymphotropic virus type I using the polymerase chain reaction. Rev. Cuba. Med. Trop. 1997, 49, 204-208.

226. Trejo-Avila, L.M.; Fuentes-Pensamiento, R.; Scorro, M.F.; Diaz-Mendoza, M.L.; Zapata-Benavides, P.; Tamez-Guerra, R.S. Seroprevalence of HTLV-I/II in blood donors in Monterrey, Mexico. Arch. Med. Res. 1996, 27, 97-99. [PubMed]

227. Kato-Maeda, M.; Ponce-de-León, S.; Sifuentes-Osornio, J.; Rangel-Frausto, M.S.; Calva-Mercado, J.; Infante-Surez, L.; Villareal, F.M.; Ponce-de-León, S. Bloodborne viral infections in patients attending an emergency room in Mexico City: Estimate of seroconversion probability in healthcare workers after an occupational exposure. Infect. Control. Hosp. Epidemiol. 2000, 21, 600-602. [CrossRef] [PubMed]

228. Gongora-Biachi, R.A.; Gonzalez-Martinez, P.; Castro-Sansores, C.; Bastarrachea-Ortiz, J. Infection with HTLV virus type I-II in patients with cervico-uterine cancer in the Yucatan peninsula, Mexico. Ginecol. Obstet. Mex. 1997, 65, 141-144. [PubMed] 
229. Reeves, W.C.; Saxinger, C.; Brenes, M.M.; Quiroz, E.; Clark, J.W.; Hoh, M.W.; Blattner, W.A. Human T-cell lymphotropic virus type I (HTLV-I) seroepidemiology and risk factors in metropolitan Panama. Am. J. Epidemiol. 1988, 127, 532-539. [CrossRef] [PubMed]

230. Leon, A.; Dias, R.; Gracia, F. T-cell lymphoma/leukemia secondary to HTLV-1 in adults. Report of a case. Rev. Med. Panama 1998, 23, 41-46.

231. Levine, P.H.; Reeves, W.C.; Cuevas, M.; Arosemena, J.R.; Jaffe, E.S.; Saxinger, W.C.; Altafulla, M.; De Bernal, J.; Espino, H.; Rios, B.; et al. Human T-cell leukemia virus-I and hematologic malignancies in Panama. Cancer 1989, 63, 2186-2191. [CrossRef]

232. De Rivera, I.L.; Amador, L.; Mourra, S.; Li, Z.; Rasheed, S. Geographical clustering of human T-cell lymphotropic virus type 1 infection in Honduras. J. Clin. Microbiol. 1995, 33, 2999-3003. [CrossRef]

233. Segurado, A.; Granade, T.; Parekh, B.; Nunez, C.A.; Meza, R.; Amador, L.; Terrell, S.; George, J.R.; Lal, R.B. Presence of HTLV-I and HTLV-II infection in Honduras. J. Acquir. Immune Defic. Syndr. Hum. Retrovirol. 1997, 16, 308. [CrossRef]

234. Temple, J.J.; Brammer, M.G.; Andes, W.A.; Covington, S.; Rangan, S. Adult T-cell leukemia-lymphoma. Unusual features of two patients from a low-incidence area. Cancer 1986, 58, 694-698. [CrossRef]

235. Qiu, X.; Hodges, S.; Lukaszewska, T.; Hino, S.; Arai, H.; Yamaguchi, J.; Swanson, P.; Schochetman, G.; Devare, S.G. Evaluation of a new, fully automated immunoassay for detection of HTLV-I and HTLV-II antibodies. J. Med. Virol. 2008, 80, 484-493. [CrossRef]

236. Leon, G.; Quiros, A.M.; Lopez, J.L.; Hung, M.; Diaz, A.M.; Goncalves, J.; Da Costa, O.; Hernandez, T.; Chirinos, M.; Gomez, R. Seropositivity for human T-lymphotropic virus types I and II among donors at the Municipal Blood Bank of Caracas and associated risk factors. Panam. Salud Pública 2003, 13, 117-123. [CrossRef] [PubMed]

237. Merino, F.; Robert-Guroff, M.; Clark, J.; Biondo-Bracho, M.; Blattner, W.A.; Gallo, R.C. Natural antibodies to human T-cell leukemia/lymphoma virus in healthy Venezuelan populations. Int. J. Cancer 1984, 34, 501-506. [CrossRef] [PubMed]

238. Márquez, Y.; Pimentel, Z.; Castillo, S.; SANTIAGO, M.; URDANETA, J.; MARTÍNEZ, A.; ESCALONA, P. Frecuencia del virus linfotropico de las células $t$ humanas tipo i/ii en pacientes que asisten a la unidad programática regional de inmunología clínica del estado Aragua, Venezuela, 2012. SABER. Rev. Multidiscip. Cons. Investig. Univ. Oriente 2016, 28, 83-89.

239. Bermudez-Forero, M.I.; Berrio-Perez, M.; Herrera-Hernandez, A.M.; Rodriguez-Rodriguez, M.J.; Garcia-Blanco, S.; Orjuela-Falla, G.; Beltran, M. Prevalence of human T-cell lymphotropic virus I and II in Colombian blood donors, 2001-2014: Implications for transfusion safety. Biomedica 2016, 36, 194-200. [PubMed]

240. Macía, C.; Vargas, S.; Mora, A.M.; Sarmiento, A.M.; Pacheco, R.; Rosso, F. Seroprevalence of human T-lymphotropic virus in blood bank donors at Fundación Valle del Lili, Cali, Colombia, 2008-2014. Biomedica 2016, 36, 108-115. [CrossRef]

241. Trujillo, J.M.; Concha, M.; Munoz, A.; Bergonzoli, G.; Mora, C.; Borrero, I.; Gibbs, C.J., Jr.; Arango, C. Seroprevalence and cofactors of HTLV-I infection in Tumaco, Colombia. AIDS Res. Hum. Retrovir. 1992, 8, 651-657. [CrossRef]

242. Martínez-Nieto, O.; Isaza-Ruget, M.; Rangel-Espinosa, N.; Morales-Reyes, O.L. Human T-lymphotropic virus (HTLV I/II) seroprevalence amongst blood-donors in a hospital Bogotá, Colombia, between 1999 and 2004. Rev. Salud Pública 2007, 9, 253-261. [CrossRef]

243. Cardona-Arias, J.A.; Velez-Quintero, C.; Calle-Gonzalez, O.V.; Florez-Duque, J.; Zapata, J.C. Seroprevalence of human T-lymphotropic virus HTLV and its associated factors in donors of a blood bank of Medellin-Colombia, 2014-2018. PLOS ONE 2019, 14, e0221060. [CrossRef]

244. Munoz, M.; Carvalho, S.; Donado, J.H.; Barco, G.E.; Jaramillo, S. SHTLV-I/II seroprevalence in blood donors of Hospital Pablo Tobon Uribe Blood Bank during the period 2014-2015. Biomedica 2018, 38, 37-41. [CrossRef]

245. Maloney, E.M.; Ramirez, H.; Levin, A.; Blattner, W.A. A survey of the human T-cell lymphotropic virus type I (HTLV-I) in south-western Colombia. Int. J. Cancer 1989, 44, 419-423. [CrossRef]

246. Valencia, M.; Moreno, L. Comorbidity between HTLV-1-associated adult T-cell lymphoma/leukemia and verrucous carcinoma: A case report. Colomb. Med. 2017, 48, 35-38. [CrossRef] [PubMed]

247. Blank, A.; Yamaguchi, K.; Blank, M.; Zaninovic, V.; Sonoda, S.; Takatsuki, K. Six Colombian patients with adult T-cell leukemia/lymphoma. Leuk. Lymphoma 1993, 9, 407-412. [CrossRef] [PubMed] 
248. Medina, E.A.; Orduz, R.; Morales, O.L.; Martinez, O.; Baldion, M.; Isaza, M.A. Adult T-cell leukemia/lymphoma in HTLV-1 infected patients: Report of two cases in Colombia. Biomedica 2013, 33, 519-525. [CrossRef] [PubMed]

249. Dominguez, M.C.; Torres, M.; Tamayo, O.; Criollo, W.; Quintana, M.; Sanchez, A.; Garcia, F. Autoimmune syndrome in the tropical spastic paraparesis/myelopathy associated with human T-lymphotropic virus infections. Biomedica 2008, 28, 510-522. [PubMed]

250. Mosquera-Herrera, C.E.; Aspiazu-Miranda, E.P.; de Waard, J.H.; Garcia-Bereguiain, M.A. A high prevalence of human T-lymphotropic virus (HTLV 1/2) infection among Afro-descendants, Esmeraldas province, Ecuador-Need for the implementation of surveys and control programs. Infect. Drug Resist. 2019, 12, 1969-1974. [CrossRef]

251. Guderian, R.; Guevara, A.; Cooper, P.; Rugeles, M.T.; Arango, C. HTLV-1 infection and tropical spastic paraparesis in Esmeraldas Province of Ecuador. Trans. R. Soc. Trop. Med. Hyg. 1994, 88, 399-400. [CrossRef]

252. Cevallos, R.; Barberis, L.; Evans, L.; Barriga, J.; Verdier, M.; Bonis, J.; Leonard, G.; Denis, F. HIV-1, HIV-2 and HTLV-I seroprevalence surveys in continental Ecuador and Galapagos. Aids 1990, 4, 1300-1301. [CrossRef]

253. Ramirez-Soto, M.C.; Huichi-Atamari, M. Prevalence of hepatitis B and human T-lymphotropic virus infection among blood donors at a hospital in the south-central highlands of Peru. Transfus. Med. 2018, 28, 263-265. [CrossRef]

254. Quispe, N.C.; Feria, E.B.; Santos-Fortuna Ede, L.; Caterino-de-Araujo, A. Confirming the presence of HTLV-1 infection and the absence of HTLV-2 in blood donors from Arequipa, Peru. Rev. Inst. Med. Trop. São Paulo 2009, 51, 25-29. [CrossRef]

255. Cárcamo, C.P.; Campos, P.E.; García, P.J.; Hughes, J.P.; Garnett, G.P.; Holmes, K.K. Prevalences of sexually transmitted infections in young adults and female sex workers in Peru: A national population-based survey. Lancet Infect. Dis. 2012, 12, 765-773. [CrossRef]

256. Alarcon, J.O.; Friedman, H.B.; Montano, S.M.; Zunt, J.R.; Holmes, K.K.; Quinnan, G.V., Jr. High endemicity of human T-cell lymphotropic virus type 1 among pregnant women in peru. J. Acquir. Immune Defic. Syndr. 2006, 42, 604-609. [CrossRef] [PubMed]

257. Guevara Miranda, J.; Guzman Rojas, P.; Mejia Cordero, F.A. Acute liver failure as presentation of adult T-cell leukemia in an HTLV-1 patient. Rev. Gastroenterol. Peru 2018, 38, 85-88. [PubMed]

258. Guevara Miranda, J.; Guzman Rojas, P.; Espinoza-Rios, J.; Mejia Cordero, F. Duodenal Linphoma asociated to Strongyloides stercoralis infection. Two types of HTLV-1 infection. Rev. Gastroenterol. Peru 2017, 37, 169-172. [PubMed]

259. Rodriguez-Zuniga, M.J.; Cortez-Franco, F.; Qujiano-Gomero, E. Adult T-cell leukemia/lymphoma in a Peruvian hospital in human T-lymphotropic virus type 1 (HTLV-1) positive patients. Int. J. Dermatol. 2017, 56, 503-509. [CrossRef]

260. Beltran, B.E.; Quinones, P.; Morales, D.; Revilla, J.C.; Alva, J.C.; Castillo, J.J. Diffuse large B-cell lymphoma in human T-lymphotropic virus type 1 carriers. Leuk. Res. Treat. 2012, 2012, 4. [CrossRef]

261. Barros, N.; Woll, F.; Watanabe, L.; Montes, M. Are increased Foxp3 ${ }^{+}$regulatory T cells responsible for immunosuppression during HTLV-1 infection? Case reports and review of the literature. BMJ Case Rep. 2012, 2012, e006574. [CrossRef]

262. Beltran, B.; Palomino, E.; Quinones, P.; Morales, D.; Cotrina, E. Gastric adult T cell leukemia/lymphoma: Report of four cases and review of literature. Rev. Gastroenterol. Peru 2010, 30, 153-157.

263. Delgado, S.; Gotuzzo, E. Adult T cell lymphoblastic leukemia/lymphoma by HTLV-1 in a young woman. Rev. Chilena Infectol. 2019, 36, 234-237. [CrossRef]

264. San Martin, H.; Balanda, M.; Vergara, N.; Valenzuela, M.A.; Cartier, L.; Ayala, S.; Ramirez, E. Human T-Lymphotropic Virus Type 1 and 2 Seroprevalence among first-time blood donors in Chile, 2011-2013. J. Med. Virol. 2016, 88, 1067-1075. [CrossRef]

265. Chandia, L.; Sotomayor, C.; Ordenes, S.; Salas, P.; Navarrete, M.; Lopez, M.; Otth, C. Seroprevalence of human T-cell lymphotropic virus type 1 and 2 in blood donors from the regional hospital of Valdivia, Chile. Med. Microbiol. Immunol. 2010, 199, 341-344. [CrossRef]

266. Cabrera, M.; Labra, S.; Meneses, P.; Matutes, E.; Cartier, L.; Ford, A.; Greaves, M. Adult T cell leukemia lymphoma in Chile. A clinical pathologic and molecular study of 26 patients. Rev. Med. Chile 1999, 127, 935-944. [PubMed]

267. Cabrera, M.E.; Labra, S.; Ford, A.; Matutes, E. HTLV-I induced intestinal lymphoma. Leuk. Lymphoma 1999, 35, 637-640. [CrossRef] [PubMed]

268. Cabrera, M.E.; Labra, S.; Catovsky, D.; Ford, A.M.; Colman, S.M.; Greaves, M.F.; Matutes, E. HTLV-I positive adult T-cell leukaemia/lymphoma (ATLL) in Chile. Leukemia 1994, 8, 1763-1767. [PubMed] 
269. Casanova, E.R.; Llancapi, P.; Bravo, A.; Fuentes, B.; Contreras, G. Adult T-cell lymphoma and Reed-Sternberg cells. A clinical case. Rev. Med. Chile 1994, 122, 1184-1188.

270. Cartier, L.; Castillo, J.L.; Cabrera, M.E.; Araya, F.; Matutes, E.; Ford, A.M.; Greaves, M.F. HTLV-I positive progressive spastic paraparesis (TSP) associated with a lymphoid disorder in three Chilean patients. Leuk. Lymphoma 1995, 17, 459-464. [CrossRef]

271. Cabrera, M.E.; Gray, A.M.; Cartier, L.; Araya, F.; Hirsh, T.; Ford, A.M.; Greaves, M.F. Simultaneous adult T-cell leukemia/lymphoma and sub-acute polyneuropathy in a patient from Chile. Leukemia 1991, 5, 350-353.

272. Montserrat, E.; Lozano, M.; Urbano-Ispizua, A.; Matutes, E.; Feliu, E.; Ercilla, G.; Vives-Corrons, J.L.; Rozman, C. Adult T-cell Leukemia in a Chilean Resident in Spain: Long-Lasting Remission after 2-Deoxycoformycin Treatment. Leuk. Lymphoma 1989, 1, 47-49. [CrossRef]

273. Barrientos, A.; Lopez, M.; Sotomayor, C.; Pilleux, L.; Calderon, S.; Navarrete, M.; Otth, C. Prevalence of human T-cell lymphotropic virus type 1 and 2 among patients with malignant hematological diseases in south Chile. J. Med. Virol. 2011, 83, 745-748. [CrossRef]

274. Cabrera, M.E.; Marinov, N.; Guerra, C.; Morilla, R.; Matutes, E. Chronic lymphoproliferative syndromes in Chile. A prospective study in 132 patients. Rev. Med. Chile 2003, 131, 291-298.

275. Martinez, V.; Franco, C.; Sazunic, I.; Puga, M.; Bronfman, L.; Rodriguez, C. Acquired immunodeficiency syndrome associated with infection by HTLV-1 virus: A clinical case. Rev. Med. Chile 1990, 118, 671-674.

276. Zoulek, G.; Schatzl, H.; Kawabata, M.; de Cabral, M.B.; Cabello, A.; Freutsmiedl, K.; Villagra, E.; von der Helm, K. A seroepidemiological survey of antibodies to HTLV-I/HTLV-II in selected population groups in Paraguay. Scand. J. Infect. Dis. 1992, 24, 397-398. [CrossRef] [PubMed]

277. Balduin, B.; Priore, C.; Acosta, C.; Salazar, E.; Rodríguez, F.; Bianchi, S.; Pritsch, O. Infección por virus linfotrópico de células T humanas (HTLV) en Uruguay: Identificación de problemas. An. Fac. Med. Univ. Repúb. Urug. 2017, 4, 41-51.

278. Muchinik, G.; Bouzas, M.B.; Zapiola, I.; Decaro, J.; García, L.; Gallo, D.; Hanson, C.V. HTLV-I and HTLV-II infection in Uruguay. J. Acquir. Immune Defic. Syndr. 1992, 5, 743-744. [PubMed]

279. Boada, M.; Grille, S.; Brugnini, A.; Trias, N.; Canesa, C.; Diaz, L.; Lens, D. Adult T-cell leukemia/lymphoma. Report of a case in Uruguay. Medicina 2017, 77, 235-238.

280. Biglione, M.; Pizarro, M.; Crespo, O.; Severich, I.; Martínez Peralta, L.; Libonatti, O.; Mercedes Avila, M.; Astarloa, L. High prevalence of HTLV-I infection in Argentinian blood donors: A new HTLV-I-endemic area? J. Acquir. Immune Defic. Syndr. Hum. Retrovirol. 1999, 20, 101-102. [CrossRef]

281. Del Pino, N.; Martínez Peralta, L.; Pampuro, S.; Pimentel, E.; Libonatti, O. HTLV-I/II seroprevalence and coinfection with other pathogens in blood donors in Buenos Aires. J. Acquir. Immune Defic. Syndr. 1994, 7, $206-207$.

282. Borda, M.A.; Svibel, G.R.; Biglione, M.M.; Berini, C.A. Detection of Human T lymphotropic virus 1 (HTLV-1) Cosmopolitan subtype Transcontinental subgroup (Aa) and HTLV-2 subtype b in blood donors of Corrientes. Rev. Argent. Microbiol. 2019, 51, 307-315.

283. Moreno, C.; Balangero, M.; Barbás, M.G.; Cudolá, A.; Gallego, S. Serological diagnosis of HTLV-1/2: Combination of screening assays to define the serological status in blood donors. Rev. Argent. Microbiol. 2013, 45, 165-168.

284. Biglione, M.M.; Astarloa, L.; Salomon, H.E. High prevalence of HTLV-I and HTLV-II among blood donors in Argentina: A South American health concern. AIDS Res. Hum. Retrovir. 2005, 21, 1-4. [CrossRef]

285. Bouzas, M.B.; Muchinik, G.R.; Zapiola, I.; De Rosa, M.F.; Perez Bianco, R.; Pimentel, E.; Dengra, C.; Del Pino, N.; Gallo, D.; Hanson, C.V. Prevalence of HTLV-I/II among blood bank donors in Argentina. J. Acquir. Immune Defic. Syndr. 1992, 5, 1275-1276. [CrossRef]

286. Gutfraind, Z.; Blejer, J.L.; Saguier, M.C.; Gomez Carretero, M.L.; Pirola, D.A.; Carreras Vescio, L.A. Seroprevalence of HTLV-I/HTLV-II in blood donors in Buenos Aires (Argentina). Vox Sang. 1994, 67, 408-409. [CrossRef] [PubMed]

287. Gutfraind, Z.; Blejer, J.L.; Saguier, M.C.; Gomez Carretero, M.L.; Pirola, D.A.; Carreras Vescio, L.A. Evaluation of HTLV-I/II infection in blood donors in Buenos Aires. Medicina 1995, 55, 295-299. [PubMed]

288. Blejer, J.L.; Saguier, M.C.; Salamone, H.J.; Carreras, L.A. Determination of anti-HTLV-I/II antibodies: Experience in 28,897 blood donations in Buenos Aires. Sangre 1995, 40, 447-451. [PubMed]

289. Gallego, S.; Maturano, E.; Recalde, A.; Gastaldello, R.; Sileoni, S.; Bepre, H.; Medeot, S. HTLV-I/II seroprevalence and risk factors associated with infection in a blood donor population in Cordoba, Argentina. Rev. Argent. Microbiol. 2001, 33, 182-186. 
290. Gastaldello, R.; Fazzola, P.; Caeiro, L.; Maturano, E.; Perez De Rosas, A.; Fernandez, I.; Racca, R.; Rodriguez, M.B.; Molina, M.; Alonso, S.; et al. Absence of HTLV-I/II virus circulation in blood donors from the provinces of Santa Fe and Santiago del Estero. Rev. Argent. Microbiol. 2002, 34, 107-109.

291. Remesar, M.; Mangano, A.; Sen, L.; del Pozo, A. Profile of human T-cell lymphocytotrophic virus-I/II infections in an Argentinean blood bank population. Vox Sang. 2002, 83, 364-365. [CrossRef]

292. Gastaldello, R.; Hall, W.W.; Gallego, S. Seroepidemiology of HTLV-I/II in Argentina: An overview. J. Acquir. Immune Defic. Syndr. 2004, 35, 301-308. [CrossRef]

293. Mangano, A.M.; Remesar, M.; del Pozo, A.; Sen, L. Human T lymphotropic virus types I and II proviral sequences in Argentinian blood donors with indeterminate Western blot patterns. J. Med. Virol. 2004, 74, 323-327. [CrossRef]

294. Brun, R.O.; Astarloa, L.; Salomon, H.E.; Biglione, M.M. Prevalence of HTLV-I/II infection among blood donors in Santa Fe Province, Argentina. Medicina 2004, 64, 125-128.

295. Malan, R.; Berini, C.A.; Eirin, M.E.; Delfino, C.M.; Pedrozo, W.; Krupp, R.; Garcia Plichta, A.; Biglione, M.M. Seroprevalence of HTLV-1/2 in blood donors from Misiones Province. Medicina 2010, 70, 71-74.

296. Berini, C.A.; Gendler, S.A.; Pascuccio, S.; Eirin, M.E.; McFarland, W.; Page, K.; Carnevali, L.; Murphy, E.; Biglione, M.M. Decreasing trends in HTLV-1/2 but stable HIV-1 infection among replacement donors in Argentina. J. Med. Virol. 2010, 82, 873-877. [CrossRef] [PubMed]

297. Trenchi, A.; Gastaldello, R.; Balangero, M.; Irizar, M.; Cudolá, A.; Gallego, S. Retrospective study of the prevalence of human T-cell lymphotropic virus-type 1/2, HIV, and HBV in pregnant women in Argentina. J. Med. Virol. 2007, 79, 1974-1978. [CrossRef] [PubMed]

298. Marin, O.; Hasui, K.; Remondegui, C.; Sato, E.; Aye, M.M.; Takenouchi, N.; Izumo, S.; Tajima, K. Adult T-cell leukemia/lymphoma in Jujuy, north-west Argentina. Pathol. Int. 2002, 52, 348-357. [CrossRef] [PubMed]

299. Fourcade, C.; Jarry, L.; Mechler, C.; Lionnet, F.; Dardel, P. Association of B-cell lymphoma and T-cell lymphoma in HTLV1 infection. Ann. Biol. Clin. 1997, 55, 491-493.

300. Gioseffi, O.N.; Nucifora, E.; Fantl, D.; Dufour, C.; Milone, J.; Di Paolo, H. Adult HTLV-I positive leukemia-lymphoma in Argentina. Sangre 1995, 40, 421-424.

301. Prates, V.; Cobos, M.; Bouzas, B.; Napal, J.; Bordone, J.; Milone, J. The first report of familial adult T-cell leukemia/lymphoma in Argentina. Leuk. Lymphoma 2000, 37, 225-227. [CrossRef]

302. Pinto, M.T.; Rodrigues, E.S.; Malta, T.M.; Azevedo, R.; Takayanagui, O.M.; Valente, V.B.; Ubiali, E.M.; Covas, D.T.; Kashima, S. HTLV-1/2 seroprevalence and coinfection rate in Brazilian first-time blood donors: An 11-year follow-up. Rev. Inst. Med. Trop. São Paulo 2012, 54, 123-129. [CrossRef]

303. Catalan-Soares, B.; Carneiro-Proietti, A.B.; Proietti, F.A. Heterogeneous geographic distribution of human T-cell lymphotropic viruses I and II (HTLV-I/II): Serological screening prevalence rates in blood donors from large urban areas in Brazil. Cad. Saúde Pública 2005, 21, 926-931. [CrossRef]

304. Dourado, I.; Alcantara, L.C.; Barreto, M.L.; da Gloria Teixeira, M.; Galvao-Castro, B. HTLV-I in the general population of Salvador, Brazil: A city with African ethnic and sociodemographic characteristics. J. Acquir. Immune Defic. Syndr. 2003, 34, 527-531. [CrossRef]

305. Carneiro-Proietti, A.B.; Sabino, E.C.; Leao, S.; Salles, N.A.; Loureiro, P.; Sarr, M.; Wright, D.; Busch, M.; Proietti, F.A.; Murphy, E.L. Human T-lymphotropic virus type 1 and type 2 seroprevalence, incidence, and residual transfusion risk among blood donors in Brazil during 2007-2009. AIDS Res. Hum. Retrovir. 2012, 28, 1265-1272. [CrossRef]

306. Reboucas, K.; Narici, F.M.; Santos Junior, M.N.; Neres, N.S.M.; Oliveira, M.V.; Souza, C.L. Seroprevalence of transfusion-transmissible infectious diseases at a hemotherapy service located in southwest Bahia, Brazil. Hematol. Transfus. Cell Ther. 2019, 41, 324-328. [CrossRef] [PubMed]

307. Pessoni, L.L.; Aquino, E.C.; Alcantara, K.C. Prevalence and trends in transfusion-transmissible infections among blood donors in Brazil from 2010 to 2016. Hematol. Transfus. Cell. Ther. 2019, 41, 310-315. [CrossRef] [PubMed]

308. Pereira, F.M.; de Almeida, M.; Santos, F.L.N.; Carreiro, R.P.; Regis-Silva, C.G.; Galvao-Castro, B.; Grassi, M.F.R. Evidence of New Endemic Clusters of Human T-Cell Leukemia Virus (HTLV) Infection in Bahia, Brazil. Front. Microbiol. 2019, 10, 1002. [CrossRef] [PubMed]

309. Silva, I.C.; Pinheiro, B.T.; Nobre, A.F.S.; Coelho, J.L.; Pereira, C.C.C.; Ferreira, L.S.C.; Almeida, C.P.S.; Viana, M.; Almeida, D.S.; Falcao, J.R.; et al. Moderate endemicity of the human T-lymphotropic virus infection in the metropolitan region of Belem, Para, Brazil. Rev. Bras. Epidemiol. 2018, 21, e180018. 
310. Ribeiro, I.P.; Kozlowski, A.G.; Dias de Matos, M.A.; da Costa E Silva, Á.M.; dos Santos Carneiro, M.A.; Vicente, A.C.P.; Martins, R.M.B. HTLV-1 and-2 in a first-time blood donor population in Northeastern Brazil: Prevalence, molecular characterization, and evidence of intrafamilial transmission. J. Med. Virol. 2018, 90, 1651-1657. [CrossRef]

311. Morais, M.P.E.; Gato, C.M.; Maciel, L.A.; Lalwani, P.; Costa, C.A.; Lalwani, J.D.B. Prevalence of Human T-lymphotropic virus type 1 and 2 among blood donors in Manaus, Amazonas State, Brazil. Rev. Inst. Med. Trop. São Paulo 2017, 59, 7. [CrossRef]

312. De Aguiar, S.A.; de Souza França, S.A.; Santana, B.B.; Santos, M.B.; Freitas, F.B.; Ferreira, G.; Cayres-Vallinoto, I.; Ishak, M.O.G.; Ishak, R.; Vallinoto, A.C.R. Human T-lymphotropic virus 1aA circulation and risk factors for sexually transmitted infections in an Amazon geographic area with lowest human development index (Marajo Island, Northern Brazil). BMC Infect. Dis. 2017, 17, 758. [CrossRef]

313. Nunes, D.; Boa-Sorte, N.; Grassi, M.F.; Taylor, G.P.; Teixeira, M.G.; Barreto, M.L.; Dourado, I.; Galvão-Castro, B. HTLV-1 is predominantly sexually transmitted in Salvador, the city with the highest HTLV-1 prevalence in Brazil. PLoS ONE 2017, 12, e0171303. [CrossRef]

314. Gomes, F.V.; Eleutério Junior, J. HTLV-II in blood donors at the Blood Center Net of Ceara-HEMOCE. Rev. Assoc. Méd. Bras. (1992) 2011, 57, 309-312. [CrossRef]

315. Dias-Bastos, M.R.; Oliveira, C.D.L.; Carneiro-Proietti, A.B.D.F. Decline in prevalence and asymmetric distribution of human T cell lymphotropic virus 1 and 2 in blood donors, State of Minas Gerais, Brazil, 1993 to 2007. Rev. Soc. Bras. Med. Trop. 2010, 43, 615-619. [CrossRef]

316. Lima, G.M.; Eustaquio, J.M.; Martins, R.A.; Josahkian, J.A.; Pereira Gde, A.; Moraes-Souza, H.; Martins, P.R. Decline in the prevalence of HTLV-1/2 among blood donors at the Regional Blood Center of the City of Uberaba, State of Minas Gerais, from 1995 to 2008. Rev. Soc. Bras. Med. Trop. 2010, 43, 421-424. [CrossRef] [PubMed]

317. Namen-Lopes, M.S.; Martins, M.L.; Drummond, P.C.; Lobato, R.R.; Carneiro-Proietti, A.B. Lookback study of HTLV-1 and 2 seropositive donors and their recipients in Belo Horizonte, Brazil. Transfus. Med. 2009, 19, 180-188. [CrossRef] [PubMed]

318. Pinto, M.T.; Slavov, S.N.; Valente, V.B.; Ubiali, E.M.; Covas, D.T.; Kashima, S. Evaluation of human T-lymphotropic virus prevalence/co-infection rates for a four-year period in a non-metropolitan blood center in Southeast Brazil. Rev. Soc. Bras. Med. Trop. 2016, 49, 232-236. [CrossRef] [PubMed]

319. Viana, G.M.; Nascimento Mdo, D.; de Oliveira, R.A.; Dos Santos, A.C.; Galvao Cde, S.; da Silva, M.A. Seroprevalence of HTLV-1/2 among blood donors in the state of Maranhao, Brazil. Revi. Bras. Hematol. Hemoter. 2014, 36, 50-53. [CrossRef] [PubMed]

320. Colin, D.D.; Alcantara Junior, L.C.; Santos, F.L.; Uchoa, R.; Tavares-Neto, J. Seroprevalence of human T cell lymphotropic virus infection and associated factors of risk in blood donors of Rio Branco city, AC, Brazil (1998-2001). Rev. Soc. Bras. Med. Trop. 2003, 36, 677-683. [CrossRef] [PubMed]

321. Segurado, A.A.; Malaque, C.M.; Sumita, L.M.; Pannuti, C.S.; Lal, R.B. Laboratory characterization of human T cell lymphotropic virus types 1 (HTLV-1) and 2 (HTLV-2) infections in blood donors from Sao Paulo, Brazil. Am. J. Trop. Med. Hyg. 1997, 57, 142-148. [CrossRef]

322. Ferreira Junior, O.C.; Vaz, R.S.; Carvalho, M.B.; Guerra, C.; Fabron, A.L.; Rosemblit, J.; Hamerschlak, N. Human T-lymphotropic virus type I and type II infections and correlation with risk factors in blood donors from Sao Paulo, Brazil. Transfusion 1995, 35, 258-263. [CrossRef]

323. Oliveira, P.D.; Gomes, I.; Souza, V.H.; Pires, E.C.; Arruda, G.B.; Bittencourt, A. Adult T-cell leukemia/lymphoma treatment in Bahia, Brazil. Revi. Bras. Hematol. Hemoter. 2017, 39, 13-19. [CrossRef]

324. Bittencourt, A.L.; Barbosa, H.S.; Vieira, M.D.; Farre, L. Adult T-cell leukemia/lymphoma (ATL) presenting in the skin: Clinical, histological and immunohistochemical features of 52 cases. Acta Oncol. 2009, 48, 598-604. [CrossRef]

325. Farre, L.; de Oliveira Mde, F.; Primo, J.; Vandamme, A.M.; Van Weyenbergh, J.; Bittencourt, A.L. Early sequential development of infective dermatitis, human $\mathrm{T}$ cell lymphotropic virus type 1-associated myelopathy, and adult T cell leukemia/lymphoma. Clin. Infect. Dis. 2008, 46, 440-442. [CrossRef]

326. Bittencourt, A.L.; da Gracas Vieira, M.; Brites, C.R.; Farre, L.; Barbosa, H.S. Adult T-cell leukemia/lymphoma in Bahia, Brazil: Analysis of prognostic factors in a group of 70 patients. Am. J. Clin. Pathol. 2007, 128, 875-882. [CrossRef] [PubMed] 
327. Sakamoto, F.H.; Colleoni, G.W.; Teixeira, S.P.; Yamamoto, M.; Michalany, N.S.; Almeida, F.A.; Chiba, A.K.; Petri, V.; Fernandes, M.A.; Pombo-de-Oliveira, M.S. Cutaneous T-cell lymphoma with HTLV-I infection: Clinical overlap with adult T-cell leukemia/lymphoma. Int. J. Dermatol. 2006, 45, 447-449. [CrossRef] [PubMed]

328. Pombo-de-Oliveira, M.S.; Dobbin, J.A.; Loureiro, P.; Borducchi, D.; Maia, R.C.; Fernandes, M.A.; Cavalcanti, G.B., Jr.; Takemoto, S.; Franchini, G. Genetic mutation and early onset of T-cell leukemia in pediatric patients infected at birth with HTLV-I. Leuk. Res. 2002, 26, 155-161. [CrossRef]

329. Pombo de Oliveira, M.S.; Matutes, E.; Schulz, T.; Carvalho, S.M.; Noronha, H.; Reaves, J.D.; Loureiro, P.; Machado, C.; Catovsky, D. T-cell malignancies in Brazil. Clinico-pathological and molecular studies of HTLV-I-positive and -negative cases. Int. J. Cancer 1995, 60, 823-827. [CrossRef]

330. De Oliveira, M.S.; Matutes, E.; Famadas, L.C.; Schulz, T.F.; Calabro, M.L.; Nucci, M.; Andrada-Serpa, M.J.; Tedder, R.S.; Weiss, R.A.; Catovsky, D. Adult T-cell leukaemia/lymphoma in Brazil and its relation to HTLV-I. Lancet 1990, 336, 987-990. [CrossRef]

331. Bittencourt, A.L.; Andrade, A.C.; Requião, C.; Arruda, M.D.; Araújo, I. Prolonged lymphocytosis as the first manifestation of Hodgkin-like adult T-cell leukemia/lymphoma. Braz. J. Infect. Dis. 2017, 21, 119-122. [CrossRef]

332. Dos Santos, V.M.; Ribeiro, E.F.; de Faria, P.S.; Barros, I.A.; Oliveira, M.M. A 61-year-old woman with adult T-cell leukemia/lymphoma. Rom. J. Morphol. Embryol. 2016, 57, 563-566.

333. Oliveira, P.D.; Salvino, M.A.; Santos, H.H.; Bittencourt, A.L. An Unusual Association of Adult T-Cell Leukemia/Lymphoma With Hyalohyphomycosis. Am. J. Dermatopathol. 2016, 38, 370-373. [CrossRef]

334. Viana, G.M.; da Silva, M.A.; Souza, V.L.; Lopes, N.B.; Nascimento Mdo, D. Endemic transmission of HTLV-2 in blood donors from São Luís do Maranhão, northeastern Brazil: Report of two asymptomatic individuals. Revi. Bras. Hematol. Hemoter. 2015, 37, 130-131. [CrossRef]

335. Salles, F.; Bacellar, A.; Amorim, M.; Orge, G.; Sundberg, M.; Lima, M.; Santos, S.; Porto, A.; Carvalho, E. Treatment of strongyloidiasis in HTLV-1 and Strongyloides stercoralis coinfected patients is associated with increased TNFalpha and decreased soluble IL2 receptor levels. Trans. R. Soc. Trop. Med. Hyg. 2013, 107, 526-529. [CrossRef]

336. Oliveira, P.D.; Magalhaes, M.; Argolo, J.M.; Bittencourt, A.L.; Farre, L. Double integration band of HTLV-1 in a young patient with infective dermatitis who developed an acute form of adult T-cell leukemia/lymphoma. J. Clin. Virol. 2013, 56, 163-166. [CrossRef] [PubMed]

337. Lyra-da-Silva, J.O.; de Mello Gonzaga, Y.B.; de Melo Espíndola, O.; de Andrada-Serpa, M.J.; Dib, C.; Jeunon, T. Adult T-cell leukemia/lymphoma: A case report of primary cutaneous tumoral type. Dermatol. Pract. Concept. 2012, 2, 0202a03. [CrossRef] [PubMed]

338. Olivo, R.A.; Martins, F.F.M.; Soares, S.; Moraes-Souza, H. Adult T-cell leukemia/lymphoma: Report of two cases. Rev. Soc. Bras. Med. Trop. 2008, 41, 288-292. [CrossRef] [PubMed]

339. Albuquerque, M.A.; Migliari, D.A.; Sugaya, N.N.; Kuroishi, M.; Capuano, A.C.; Sousa, S.O.; Cavalcanti, M.G. Adult T-cell leukemia/lymphoma with predominant bone involvement, initially diagnosed by its oral manifestation: A case report. Oral Surg. Oral Med. Oral Pathol. Oral Radiol. Endod. 2005, 100, 315-320. [CrossRef] [PubMed]

340. Pombo De Oliveira, M.S.; Loureiro, P.; Bittencourt, A.; Chiattone, C.; Borducchi, D.; De Carvalho, S.M.; Barbosa, H.S.; Rios, M.; Sill, A.; Cleghorn, F.; et al. Geographic diversity of adult t-cell leukemia/lymphoma in Brazil. The Brazilian ATLL Study Group. Int. J. Cancer 1999, 83, 291-298. [CrossRef]

341. Barbosa, H.S.; Bittencourt, A.L.; Barreto de Araújo, I.; Pereira Filho, C.S.; Furlan, R.; Pedrosa, C.; Lessa, G.; Harrington, W., Jr.; Galvão Castro, B. Adult T-cell leukemia/lymphoma in northeastern Brazil: A clinical, histopathologic, and molecular study. J. Acquir. Immune Defic. Syndr. 1999, 21, 65-71. [CrossRef]

342. Gongora-Biachi, R.A.; Gonzalez-Martinez, P.; Castro-Sansores, C.; Vivas-Rosel, M.L.; Gasque-Lopez, F.; Garrido-Hadad, E. Lymphotropic viruses type I and II in pregnant women in Yucatan. Rev. Investig. Clin. 1996, 48, 383-384.

343. Gongora-Biachi, R.A.; Gonzalez-Martinez, P.; Puerto, F.I.; Sosa-Munoz, J.; Duarte-Zapata, L.; Bastarrachea-Ortiz, J.; Yamaguchi, K.; Nishimura, Y.; Takatsuki, K. A low prevalence of HTLV-I/-II infection among eight population groups from Merida Yucatan, Mexico. J. Acquir. Immune Defic. Syndr. 1992, 5, 104-106.

344. Castro-Sansores, C.J.; Santos-Rivero, A.; Gonzalez-Martinez, P.; Lara-Perera, D.M.; Alonso-Salomon, G.; Gongora-Biachi, R.A. Co-infection by the human T-cell lymphotropic virus type II in patients infected by the human immunodeficiency virus in Yucatan, Mexico. Arch. Med. Res. 2006, 37, 365-369. [CrossRef]

345. Gongora-Biachi, R.A.; Lal, D.L.; Rudolph, R.B.; Castro-Sansores, C.; Gonzalez-Martinez, P.; Pavia-Ruz, N. Low prevalence of HTLV-II in Mayan Indians in the Yucatan Peninsula, Mexico. Arch. Med. Res. 1997, 28, 555-558. 
346. Guerena-Burgueno, F.; Benenson, A.S.; Sepulveda-Amor, J.; Ascher, M.S.; Vugia, D.J.; Gallo, D. Prevalence of human T cell lymphotropic virus types 1 and 2 (HTLV-1/2) in selected Tijuana subpopulations. Am. J. Trop. Med. Hyg. 1992, 47, 127-132. [CrossRef] [PubMed]

347. Zapata-Benavides, P.; Lara-Rodriguez, M.A.; Alcocer-Gonzalez, J.M.; Rodriguez-Padilla, C.; Tamez-Guerra, R.; Trejo-Avila, L.M. Seroprevalence of HTLV-I/II in different groups at risk in northeast Mexico. Vox Sang. 1996, 70, 181-182. [CrossRef] [PubMed]

348. Khabbaz, R.F.; Hartley, T.M.; Oberle, M.W.; Rosero-Bixby, L. Seroprevalence of human T-lymphotropic virus type I (HTLV-I) in Costa Rica. AIDS Res. Hum. Retrovir. 1990, 6, 959-960. [CrossRef] [PubMed]

349. Vallejo, A.; Dubon, J.M.; Garcia-Saiz, A. Presence of human T-cell lymphotropic virus types I and II infections in Honduras. J. Acquir. Immune Defic. Syndr. Hum. Retrovirol. 1996, 12, 529-530. [CrossRef] [PubMed]

350. Castillo, L.C.; Gracia, F.; Roman, G.C.; Levine, P.; Reeves, W.C.; Kaplan, J. Spinocerebellar syndrome in patients infected with human T-lymphotropic virus types I and II (HTLV-I/HTLV-II): Report of 3 cases from Panama. Acta Neurol. Scand. 2000, 101, 405-412. [CrossRef]

351. Gracia, F.; Castillo, L.; de Lao, S.L.; Archibold, C.A.; Larreategui, M.; Reeves, W.C.; Levine, P. Neurologic diseases associated with the HTLV-1 virus in Panama. Rev. Med. Panama 1990, 15, 197-203.

352. Gracia, F.; Castillo, L.C.; Larreategui, M.; Roberts, B.; Cedeno, V.; Heneine, W.; Blattner, W.; Kaplan, J.E.; Levine, P.H. Relation between human T-lymphotropic virus type I and neurologic diseases in Panama: 1985-1990. J. Acquir. Immune Defic. Syndr. Hum. Retrovirol. 1995, 10, 192-197. [CrossRef]

353. Gracia, F.; Reeves, W.C.; Levine, P.H.; Cuevas, M.; Castillo, L.; Chavarria, R.; Grimaldo, V.; Triana, E.; Arosemena, J.R.; Blattner, W.A. Human T-cell lymphotropic virus type I and neurologic disease in Panama, 1985 and 1986. Arch. Neurol. 1990, 47, 634-639. [CrossRef]

354. Ohtsu, T.; Tsugane, S.; Tobinai, K.; Shimoyama, M.; Nanri, S.; Watanabe, S. Prevalence of antibodies to human T-cell leukemia/lymphoma virus type I and human immunodeficiency virus in Japanese immigrant colonies in Bolivia and Bolivian natives. Jpn. J. Cancer Res. 1987, 78, 1347-1353.

355. Ferrer, J.F.; Esteban, E.; Murua, A.; Gutierrez, S.; Dube, S.; Poiesz, B.; Feldman, L.; Basombrio, M.A.; Galligan, D. Association and epidemiologic features of Trypanosoma cruzi and human T cell lymphotropic a virus type II in inhabitants of the Paraguayan Gran Chaco. Am. J. Trop. Med. Hyg. 2003, 68, 235-241. [CrossRef]

356. Brites, C.; Harrington, W., Jr.; Pedroso, C.; Martins Netto, E.; Badaro, R. Epidemiological Characteristics of HTLV-I and II Co-Infection in Brazilian Subjects Infected by HIV-1. Braz. J. Infect. Dis. 1997, 1, 42-47. [PubMed]

357. Britto, A.P.; Galvao-Castro, B.; Straatmann, A.; Santos-Torres, S.; Tavares-Neto, J. HTLV-I/II infection in the state of Bahia. Rev. Soc. Bras. Med. Trop. 1998, 31, 35-41. [CrossRef] [PubMed]

358. Dal Fabbro, M.M.; Cunha, R.V.; Boia, M.N.; Portela, P.; Botelho, C.A.; Freitas, G.M.; Soares, J.; Ferri, J.; Lupion, J. HTLV 1/2 infection: Prenatal performance as a disease control strategy in State of Mato Grosso do Sul. Rev. Soc. Bras. Med. Trop. 2008, 41, 148-151. [CrossRef] [PubMed]

359. De Oliveira, E.H.; Oliveira-Filho, A.B.; Souza, L.A.; da Silva, L.V.; Ishak, M.O.; Ishak, R.; Vallinoto, A.C. Human T-cell lymphotropic virus in patients infected with HIV-1: Molecular epidemiology and risk factors for transmission in Piaui, Northeastern Brazil. Curr. HIV Res. 2012, 10, 700-707. [CrossRef] [PubMed]

360. Guimaraes de Souza, V.; Lobato Martins, M.; Carneiro-Proietti, A.B.; Januario, J.N.; Ladeira, R.V.; Silva, C.M.; Pires, C.; Gomes, S.C.; Martins Cde, S.; Mochel, E.G. High prevalence of HTLV-1 and 2 viruses in pregnant women in Sao Luis, state of Maranhao, Brazil. Rev. Soc. Bras. Med. Trop. 2012, 45, 159-162. [CrossRef]

361. Linhares, M.I.; Eizuru, Y.; de Andrade, G.P.; Fonseca, I.B.; Carvalho Junior, L.B.; Moreira, I.T.; Minamishima, Y. Human T cell leukemia virus type 1 (HTLV-1) antibodies in healthy populations and renal transplanted patients in the north-east of Brazil. Microbiol. Immunol. 1994, 38, 475-478. [CrossRef]

362. Moreira, E.D.; Ribeiro, T.T., Jr.; Swanson, P.; Sampaio Filho, C.; Melo, A.; Brites, C.; Badaro, R.; Toedter, G.; Lee, H.; Harrington, W., Jr. Seroepidemiology of human T-cell lymphotropic virus type I/II in northeastern Brazil. J. Acquir. Immune Defic. Syndr. 1993, 6, 959-963.

363. Rego, F.F.; Alcantara, L.C.; Moura Neto, J.P.; Miranda, A.C.; Pereira Ode, S.; Goncalves Mde, S.; Galvao-Castro, B. HTLV type 1 molecular study in Brazilian villages with African characteristics giving support to the post-Columbian introduction hypothesis. AIDS Res. Hum. Retrovir. 2008, 24, 673-677. [CrossRef]

364. Sequeira, C.G.; Tamegao-Lopes, B.P.; Santos, E.J.; Ventura, A.M.; Moraes-Pinto, M.I.; Succi, R.C. Descriptive study of HTLV infection in a population of pregnant women from the state of Para, Northern Brazil. Rev. Soc. Bras. Med. Trop. 2012, 45, 453-456. [CrossRef] 
365. Vallinoto, A.C.; Azevedo, V.N.; Santos, D.E.; Caniceiro, S.; Mesquita, F.C.; Hall, W.W.; Ishak, M.O.; Ishak, R. Serological evidence of HTLV-I and HTLV-II coinfections in HIV-1 positive patients in Belem, state of Para, Brazil. Mem. Inst. Oswaldo Cruz 1998, 93, 407-409. [CrossRef]

366. Vallinoto, A.C.; Pontes, G.S.; Muto, N.A.; Lopes, I.G.; Machado, L.F.; Azevedo, V.N.; Carvalhaes, F.A.; Santos, S.E.; Guerreiro, J.F.; Ishak, M.O.; et al. Identification of human T-cell lymphotropic virus infection in a semi-isolated Afro-Brazilian quilombo located in the Marajo Island (Para, Brazil). Mem. Inst. Oswaldo Cruz 2006, 101, 103-105. [CrossRef] [PubMed]

367. Caterino-de-Araujo, A.; Sacchi, C.T.; Goncalves, M.G.; Campos, K.R.; Magri, M.C.; Alencar, W.K. Short Communication: Current Prevalence and Risk Factors Associated with Human T Lymphotropic Virus Type 1 and Human T Lymphotropic Virus Type 2 Infections Among HIV/AIDS Patients in Sao Paulo, Brazil. AIDS Res. Hum. Retrovir. 2015, 31, 543-549. [CrossRef] [PubMed]

368. Farias de Carvalho, S.M.; Pombo de Oliveira, M.S.; Thuler, L.C.; Rios, M.; Coelho, R.C.; Rubim, L.C.; Silva, E.M.; Reis, A.M.; Catovsky, D. HTLV-I and HTLV-II infections in hematologic disorder patients, cancer patients, and healthy individuals from Rio de Janeiro, Brazil. J. Acquir. Immune Defic. Syndr. Hum. Retrovirol. 1997, 15, 238-242. [CrossRef] [PubMed]

369. Monteiro, D.L.; Taquette, S.R.; Sodre Barmpas, D.B.; Rodrigues, N.C.; Teixeira, S.A.; Villela, L.H.; Boia, M.N.; Trajano, A.J. Prevalence of HTLV-1/2 in pregnant women living in the metropolitan area of Rio de Janeiro. PLoS Negl. Trop. Dis. 2014, 8, e3146. [CrossRef] [PubMed]

370. Soares, C.C.; Georg, I.; Lampe, E.; Lewis, L.; Morgado, M.G.; Nicol, A.F.; Pinho, A.A.; Salles, R.C.; Teixeira, S.L.; Vicente, A.C.; et al. HIV-1, HBV, HCV, HTLV, HPV-16/18, and Treponema pallidum infections in a sample of Brazilian men who have sex with men. PLoS ONE 2014, 9, e102676. [CrossRef]

371. Castro, L.S.; Rezende, G.R.; Fernandes, F.R.P.; Bandeira, L.M.; Puga, M.A.M.; Tanaka, T.S.O.; Weis-Torres, S.; Vicente, A.C.P.; Otsuki, K.; Motta-Castro, A.R.C. Human T cell lymphotropic virus type 1 infection among men who have sex with men in Central Brazil. Braz. J. Infect. Dis. 2018, 22, 472-476. [CrossRef]

372. Catalan-Soares, B.C.; Almeida, R.T.; Carneiro-Proietti, A.B. Prevalence of HIV-1/2, HTLV-I/II, hepatitis B virus (HBV), hepatitis $\mathrm{C}$ virus (HCV), Treponema pallidum and Trypanosoma cruzi among prison inmates at Manhuacu, Minas Gerais State, Brazil. Rev. Soc. Bras. Med. Trop. 2000, 33, 27-30. [CrossRef]

373. Kozlowski, A.G.; Matos, M.A.; Carneiro, M.A.; Lopes, C.L.; Teles, S.A.; Vicente, C.P.; Martins, R.M. Seroprevalence of Htlv in a Population of Hiv1-Infected Patients in Midwestern Brazil. Rev. Inst. Med. Trop. São Paulo 2016, 58, 80. [CrossRef]

374. Ribeiro, M.A.; Proietti, F.A.; Martins, M.L.; Januario, J.N.; Ladeira, R.V.; Oliveira Mde, F.; Carneiro-Proietti, A.B. Geographic distribution of human T-lymphotropic virus types 1 and 2 among mothers of newborns tested during neonatal screening, Minas Gerais, Brazil. Panam. Salud Pública 2010, 27, 330-337. [CrossRef]

375. Barros Kanzaki, L.I.; Casseb, J. Unusual finding of HTLV-I infection among Amazonian Amerindians. Arch. Med. Res. 2007, 38, 897-900. [CrossRef]

376. Gabbai, A.A.; Bordin, J.O.; Vieira-Filho, J.P.; Kuroda, A.; Oliveira, A.S.; Cruz, M.V.; Ribeiro, A.A.; Delaney, S.R.; Henrard, D.R.; Rosario, J.; et al. Selectivity of human T lymphotropic virus type-1 (HTLV-1) and HTLV-2 infection among different populations in Brazil. Am. J. Trop. Med. Hyg. 1993, 49, 664-671. [CrossRef] [PubMed]

377. Laurentino, R.V.; Lopes, I.G.; Azevedo, V.N.; Machado, L.F.; Moreira, M.R.; Lobato, L.; Ishak, M.O.; Ishak, R.; Vallinoto, A.C. Molecular characterization of human T-cell lymphotropic virus coinfecting human immunodeficiency virus 1 infected patients in the Amazon region of Brazil. Mem. Inst. Oswaldo Cruz 2005, 100, 371-376. [CrossRef] [PubMed]

378. Mota-Miranda, A.C.; Araujo, S.P.; Dias, J.P.; Colin, D.D.; Kashima, S.; Covas, D.T.; Tavares-Neto, J.; Galvao-Castro, B.; Alcantara, L.C. HTLV-1 infection in blood donors from the Western Brazilian Amazon region: Seroprevalence and molecular study of viral isolates. J. Med. Virol. 2008, 80, 1966-1971. [CrossRef] [PubMed]

379. Braco, I.L.J.; de Sa, K.S.G.; Waqasi, M.; Queiroz, M.A.F.; da Silva, A.N.R.; Cayres-Vallinoto, I.M.V.; Lima, S.S.; de Oliveira Guimaraes Ishak, M.; Ishak, R.; Guerreiro, J.F.; et al. High prevalence of human T-lymphotropic virus 2 (HTLV-2) infection in villages of the Xikrin tribe (Kayapo), Brazilian Amazon region. BMC Infect. Dis. 2019, 19, 459. [CrossRef]

380. Ishak, R.; Harrington, W.J., Jr.; Azevedo, V.N.; Eiraku, N.; Ishak, M.O.; Guerreiro, J.F.; Santos, S.B.; Kubo, T.; Monken, C.; Alexander, S.; et al. Identification of human T cell lymphotropic virus type IIa infection in the Kayapo, an indigenous population of Brazil. AIDS Res. Hum. Retrovir. 1995, 11, 813-821. [CrossRef] 
381. Ishak, R.; Vallinoto, A.C.; Azevedo, V.N.; Lewis, M.; Hall, W.W.; Guimaraes Ishak, M.O. Molecular evidence of mother-to-child transmission of HTLV-IIc in the Kararao Village (Kayapo) in the Amazon region of Brazil. Rev. Soc. Bras. Med. Trop. 2001, 34, 519-525. [CrossRef]

382. Nakauchi, C.M.; Linhares, A.C.; Maruyama, K.; Kanzaki, L.I.; Macedo, J.E.; Azevedo, V.N.; Casseb, J.S. Prevalence of human T cell leukemia virus-I (HTLV-I) antibody among populations living in the Amazon region of Brazil (preliminary report). Mem. Inst. Oswaldo Cruz 1990, 85, 29-33. [CrossRef]

383. Nakauchi, C.M.; Maruyama, K.; Kanzaki, L.I.; Linhares, A.C.; Azevedo, V.N.; Fukushima, T.; Miyauchi, M.; Koshikawa, N.; Tamayama, C.; Mochizuki, S.; et al. Prevalence of HTLV-I antibody among two distinct ethnic groups inhabiting the Amazon region of Brazil. Rev. Inst. Med. Trop. São Paulo 1992, 34, 323-328. [CrossRef]

384. Bouzas, M.B.; Muchinik, G.; Zapiola, I.; De Rosa, M.F.; Perez Bianco, R.; Cahn, P.; Gallo, D.; Hanson, C. Human T cell lymphotropic virus type II infection in Argentina. J. Infect. Dis. 1991, 164, 1026-1027. [CrossRef]

385. Berini, C.A.; Delfino, C.; Torres, O.; Garcia, G.; Espejo, R.; Pianciola, L.; Juarez, M.; Arribere, G.; Nadal, M.; Eirin, M.E.; et al. HTLV-1 cosmopolitan and HTLV-2 subtype $b$ among pregnant women of non-endemic areas of Argentina. Sex. Transm. Infect. 2013, 89, 333-335. [CrossRef]

386. Dipierri, J.E.; Tajima, K.; Cartier Robirosa, L.; Sonoda, S. A seroepidemiological survey of HTLV-I/II carriers in the Puna Jujeña. Medicina 1999, 59, 717-720. [PubMed]

387. Frutos, M.C.; Gastaldello, R.; Balangero, M.; Remondegui, C.; Blanco, S.; Otsuki, K.; Paulo Vicente, A.C.; Elias, D.; Mangeaud, A.; Nates, S.; et al. Silent dissemination of HTLV-1 in an endemic area of Argentina. Epidemiological and molecular evidence of intrafamilial transmission. PLoS ONE 2017, 12, e0174920. [CrossRef] [PubMed]

388. Tsugane, S.; Watanabe, S.; Sugimura, H.; Otsu, T.; Tobinai, K.; Shimoyama, M.; Nanri, S.; Ishii, H. Infectious states of human T lymphotropic virus type I and hepatitis B virus among Japanese immigrants in the Republic of Bolivia. Am. J. Epidemiol. 1988, 128, 1153-1161. [CrossRef] [PubMed]

389. Bandeira, L.M.; Uehara, S.N.; Asato, M.A.; Aguena, G.S.; Maedo, C.M.; Benites, N.H.; Puga, M.A.; Rezende, G.R.; Finotti, C.M.; Cesar, G.A.; et al. High prevalence of HTLV-1 infection among Japanese immigrants in non-endemic area of Brazil. PLoS Negl. Trop. Dis. 2015, 9, e0003691. [CrossRef]

390. Vallinoto, A.C.; Muto, N.A.; Pontes, G.S.; Machado, L.F.; Azevedo, V.N.; dos Santos, S.E.; Ribeiro-dos-Santos, A.K.; Ishak, M.O.; Ishak, R. Serological and molecular evidence of HTLV-I infection among Japanese immigrants living in the Amazon region of Brazil. Jpn. J. Infect. Dis. 2004, 57, 156-159.

391. Bandeira, L.M.; Uehara, S.N.O.; Puga, M.A.M.; Rezende, G.R.; Vicente, A.C.P.; Domingos, J.A.; do Lago, B.V.; Niel, C.; Motta-Castro, A.R.C. HTLV-1 intrafamilial transmission among Japanese immigrants in Brazil. J. Med. Virol. 2018, 90, 351-357. [CrossRef]

392. Barcellos, N.T.; Fuchs, S.C.; Mondini, L.G.; Murphy, E.L. Human T lymphotropic virus type I/II infection: Prevalence and risk factors in individuals testing for HIV in counseling centers from Southern Brazil. Sex. Transm. Dis. 2006, 33, 302-306. [CrossRef]

393. Bellei, N.C.; Granato, C.F.; Tomyiama, H.; Castelo, A.; Ferreira, O. HTLV infection in a group of prostitutes and their male sexual clients in Brazil: Seroprevalence and risk factors. Trans. R. Soc. Trop. Med. Hyg. 1996, 90, 122-125. [CrossRef]

394. Borducchi, D.M.; Oliveira, J.S.; Bordin, J.O.; Kerbauy, J. HTLV-I infection among relatives of patients with adult T-cell leukemia/lymphoma in Brazil: Analysis of infection transmission. Leuk. Lymphoma 1998, 31, 411-416. [CrossRef]

395. Broutet, N.; de Queiroz Sousa, A.; Basilio, F.P.; Sá, H.L.; Simon, F.; Dabis, F. Prevalence of HIV-1, HIV-2 and HTLV antibody, in Fortaleza, Ceara, Brazil, 1993-1994. Int. J. STD AIDS 1996, 7, 365-369. [CrossRef]

396. Cortes, E.; Detels, R.; Aboulafia, D.; Li, X.L.; Moudgil, T.; Alam, M.; Bonecker, C.; Gonzaga, A.; Oyafuso, L.; Tondo, M. HIV-1, HIV-2, and HTLV-I infection in high-risk groups in Brazil. N. Engl. J. Med. 1989, 320, 953-958. [CrossRef] [PubMed]

397. De Almeida Rego, F.F.; Mota-Miranda, A.; de Souza Santos, E.; Galvão-Castro, B.; Alcantara, L.C. Seroprevalence and molecular epidemiology of HTLV-1 isolates from HIV-1 co-infected women in Feira de Santana, Bahia, Brazil. AIDS Res. Hum. Retrovir. 2010, 26, 1333-1339. [CrossRef] [PubMed]

398. De Araujo, A.C.; Casseb, J.S.; Neitzert, E.; de Souza, M.L.; Mammano, F.; Del Mistro, A.; De Rossi, A.; Chieco-Bianchi, L. HTLV-I and HTLV-II infections among HIV-1 seropositive patients in Sao Paulo, Brazil. Eur. J. Epidemiol. 1994, 10, 165-171. [CrossRef] [PubMed] 
399. Dourado, I.; Andrade, T.; Carpenter, C.L.; Galvão-Castro, B. Risk factors for human T cell lymphotropic virus type I among injecting drug users in northeast Brazil: Possibly greater efficiency of male to female transmission. Mem. Inst. Oswaldo Cruz 1999, 94, 13-18. [CrossRef] [PubMed]

400. Etzel, A.; Shibata, G.Y.; Rozman, M.; Jorge, M.L.; Damas, C.D.; Segurado, A.A. HTLV-1 and HTLV-2 infections in HIV-infected individuals from Santos, Brazil: Seroprevalence and risk factors. J. Acquir. Immune Defic. Syndr. 2001, 26, 185-190. [CrossRef] [PubMed]

401. Galetto, L.R.; Lunge, V.R.; Béria, J.U.; Tietzmann, D.C.; Stein, A.T.; Simon, D. Short communication: Prevalence and risk factors for human T cell lymphotropic virus infection in Southern Brazilian HIV-positive patients. AIDS Res. Hum. Retrovir. 2014, 30, 907-911. [CrossRef]

402. Guimarães, M.L.; Bastos, F.I.; Telles, P.R.; Galvão-Castro, B.; Diaz, R.S.; Bongertz, V.; Morgado, M.G. Retrovirus infections in a sample of injecting drug users in Rio de Janeiro City, Brazil: Prevalence of HIV-1 subtypes, and co-infection with HTLV-I/II. J. Clin. Virol. 2001, 21, 143-151. [CrossRef]

403. Kleine Neto, W.; Sanabani, S.S.; Jamal, L.F.; Sabino, E.C. Prevalence, risk factors and genetic characterization of human T-cell lymphotropic virus types 1 and 2 in patients infected with human immunodeficiency virus type 1 in the cities of Ribeirão Preto and São Paulo. Rev. Soc. Bras. Med. Trop. 2009, 42, 264-270. [CrossRef]

404. Marcon, C.E.M.; Campos, K.R.; Silva, G.B.D.; Schuelter-Trevisol, F.; Schlindwein, A.D.; Trevisol, D.J.; Caterino-de-Araujo, A. The first survey of human T-cell lymphotropic viruses (HTLV) in HIV/AIDS patients in Santa Catarina State, Brazil. Rev. Inst. Med. Trop. São Paulo 2019, 61. [CrossRef]

405. Morimoto,H.K.; Caterino-De-Araujo, A.; Morimoto, A.A.; Reiche, E.M.; Ueda, L.T.; Matsuo, T.; Stegmann, J.W.; Reiche, F.V. Seroprevalence and risk factors for human T cell lymphotropic virus type 1 and 2 infection in human immunodeficiency virus-infected patients attending AIDS referral center health units in Londrina and other communities in Paraná, Brazil. AIDS Res. Hum. Retrovir. 2005, 21, 256-262. [CrossRef]

406. Pombo-de-Oliveira, M.S.; Carvalho, S.M.; Borducchi, D.; Dobbin, J.; Salvador, J.; Correa, R.B.; Moellman, A.; Loureiro, P.; Chiattone, C.; Rios, M. Adult T-cell leukemia/lymphoma and cluster of HTLV-I associated diseases in Brazilian settings. Leuk. Lymphoma 2001, 42, 135-144. [CrossRef] [PubMed]

407. Reiche, E.M.; Bonametti, A.M.; Morimoto, H.K.; Morimoto, A.A.; Wiechemann, S.L.; Matsuo, T.; Vissoci Reiche, F.; Vogler, I.H. Epidemiological, immunological and virological characteristics, and disease progression of HIV-1/HCV-co-infected patients from a southern Brazilian population. Int. J. Mol. Med. 2008, 21, 387-395. [PubMed]

408. Ribeiro, M.L.; Gonçales, J.P.; Morais, V.M.S.; Moura, L.; Coêlho, M. HTLV 1/2 Prevalence and risk factors in individuals with HIV/AIDS in Pernambuco, Brazil. Rev. Soc. Bras. Med. Trop. 2019, 52, e20180244. [CrossRef] [PubMed]

409. Bautista, C.T.; Pando, M.A.; Reynaga, E.; Marone, R.; Sateren, W.B.; Montano, S.M.; Sanchez, J.L.; Avila, M.M. Sexual practices, drug use behaviors, and prevalence of HIV, syphilis, hepatitis B and C, and HTLV-1/2 in immigrant and non-immigrant female sex workers in Argentina. J. Immigr. Minor. Health 2009, 11, 99-104. [CrossRef] [PubMed]

410. Berini, C.A.; Pando, M.A.; Bautista, C.T.; Eirin, M.E.; Martinez-Peralta, L.; Weissenbacher, M.; Avila, M.M.; Biglione, M.M. HTLV-1/2 among high-risk groups in Argentina: Molecular diagnosis and prevalence of different sexual transmitted infections. J. Med. Virol. 2007, 79, 1914-1920. [CrossRef]

411. Biglione, M.; Avila, M.M.; Biglione, J.; Weisburd, G.; Libonatti, O.; Gessain, A. Molecular characterization of HTLV-II from an intravenous drug addict with AIDS in Argentina. Rev. Argent. Microbiol. 1996, 28, 139-142.

412. Biglione, M.; Gessain, A.; Quiruelas, S.; Fay, O.; Taborda, M.; Fernandez, E.; Lupo, S.; Panzita, A. Endemic HTLV-II infection among Tobas and Matacos Amerindians from north Argentina. J. Acquir. Immune Defic. Syndr. 1993, 6, 631-633.

413. De los Angeles Pando, M.; Biglione, M.M.; Toscano, M.F.; Rey, J.A.; Russell, K.L.; Negrete, M.; Gianni, S.; Martinez-Peralta, L.; Salomon, H.; Sosa-Estani, S.; et al. Human immunodeficiency virus type 1 and other viral co-infections among young heterosexual men and women in Argentina. Am. J. Trop. Med. Hyg. 2004, 71, 153-159. [CrossRef]

414. Lombardi, V.; Carrillo, M.G.; Alimandi, M.; Boxaca, M.; Rossi, P.; Libonatti, O. Overt and latent HIV 1 and HTLV-I infection in cohorts of at high risk individuals in Argentina. Mol. Cell. Probes 1991, 5, 409-417. [CrossRef]

415. Medeot, S.; Nates, S.; Gallego, S.; Sileoni, S.; Maturano, E.; Recalde, Y.; Giordano, M.; Alvarez, R.B. HTLV-I/II seropositivity in populations at high risk for HIV-1 infection in Cordoba City, Argentina. J. Acquir. Immune Defic. Syndr. Hum. Retrovirol. 1998, 18, 187-188. [CrossRef] 
416. Pampuro, S.E.; Rabinovich, R.D.; Martinez Peralta, L.; Gallo, D.; Hanson, C.; Libonatti, O. Presence of human T-cell lymphotropic virus types I and II and coinfection with human immunodeficiency virus in different groups at risk in Argentina. J. Acquir. Immune Defic. Syndr. 1993, 6, 851-852. [PubMed]

417. Pando, M.A.; Bautista, C.T.; Maulen, S.; Duranti, R.; Marone, R.; Rey, J.; Vignoles, M.; Eirin, M.E.; Biglione, M.M.; Griemberg, G.; et al. Epidemiology of human immunodeficiency virus, viral hepatitis (B and C), treponema pallidum, and human T-cell lymphotropic I/II virus among men who have sex with men in Buenos Aires, Argentina. Sex. Transm Dis. 2006, 33, 307-313. [CrossRef] [PubMed]

418. Scapellato, P.G.; Bottaro, E.G.; Seoane, M.B.; Rodriguez Brieschke, M.T.; Scapellato, J.L.; Dato, A.; Vidal, G.I. Clinical, epidemiological and immunological study of patients coinfected with HIV and HTLV-1. Medicina 2004, 64, 413-418. [PubMed]

419. Flores-Castañeda, M.S.; Salinas-Carmona, M.C.; Leal-González, C.; Yáñez-Rodríguez, A.; Trejo-Avila, L.M. Antibodies against human T-cell lymphotropic viruses in subjects at high risk for HIV in Monterrey. Rev. Investig. Clin. 1992, 44, 37-41.

420. Gongora-Biachi, R.A.; Gonzalez-Martinez, P.; Castros-Sansores, C.; Pavia-Ruz, N.; Rudolph, D.L.; Lal, R.B. Human T lymphotropic virus type II (HTLV-II) infection among female prostitutes in Yucatan, Mexico. Am. J. Med. Sci. 1993, 306, 207-211. [CrossRef] [PubMed]

421. Gonzalez-Martinez, P.; Castro-Sansores, C.; Vivas-Rosel, M.L.; Gongora-Biachi, R.A. Infection by human T-cell lymphotropic virus type I/II in polytransfused patients in the state of Yucatan, Mexico. Sangre 1994, 39, 45-48. [PubMed]

422. Vazquez-Valls, E.; Campos-Lopez, P.I.; Torres-Mendoza, B.M.; Alvarez-Maya, I.; Gonzalez-Mendoza, A. Prevalence of anti-HTLV-I antibodies in HIV-seropositive individuals in Guadalajara, Mexico. J. Acquir. Immune Defic. Syndr. 1993, 6, 965-966.

423. Palenzuela, D.; Rivero, J.; Nazabal, M. Failure to detect serological evidence of HTLV-I/II infection among HIV patients in Cuba. Vox Sang. 1994, 67, 78. [CrossRef]

424. De Batänjer, E.C.; de Pérez, G.E. HTLV-I/II seroprevalence in Gay men and female sex workers on Margarita Island, Venezuela. Rev. Soc. Bras. Med. Trop. 1998, 31, 391-393. [CrossRef]

425. Stewart, J.; Heitzinger, K.; Pollett, S.; Calderón, M.; Alarcón, J.; Ton, T.G.; Zunt, J.R. The Changing Epidemiology of Human T-Cell Lymphotropic Virus Type 1 Infection in Peruvian Female Sex Workers, 1993-2010. Am. J. Trop. Med. Hyg. 2017, 96, 373-379. [CrossRef]

426. Arango, C.; Maloney, E.; Rugeles, M.T.; Bernal, E.; Bernal, C.; Borrero, I.; Herrera, S.; Restrepo, M.; Espinal, A.; Blattner, W.A. HTLV-I and HTLV-II coexist among the Embera and Inga Amerindians of Colombia. J. Acquir. Immune Defic. Syndr. Hum. Retrovirol. 1999, 20, 102-103. [CrossRef] [PubMed]

427. Duenas-Barajas, E.; Bernal, J.E.; Vaught, D.R.; Nerurkar, V.R.; Sarmiento, P.; Yanagihara, R.; Gajdusek, D.C. Human retroviruses in Amerindians of Colombia: High prevalence of human T cell lymphotropic virus type II infection among the Tunebo Indians. Am. J. Trop. Med. Hyg. 1993, 49, 657-663. [CrossRef] [PubMed]

428. Fujiyama, C.; Fujiyoshi, T.; Miura, T.; Yashiki, S.; Matsumoto, D.; Zaninovic, V.; Blanco, O.; Harrington, W., Jr.; Byrnes, J.J.; Hayami, M.; et al. A new endemic focus of human T lymphotropic virus type II carriers among Orinoco natives in Colombia. J. Infect. Dis. 1993, 168, 1075-1077. [CrossRef] [PubMed]

429. Zaninovic, V.; Sanzon, F.; Lopez, F.; Velandia, G.; Blank, A.; Blank, M.; Fujiyama, C.; Yashiki, S.; Matsumoto, D.; Katahira, Y.; et al. Geographic independence of HTLV-I and HTLV-II foci in the Andes highland, the Atlantic coast, and the Orinoco of Colombia. AIDS Res. Hum. Retrovir. 1994, 10, 97-101. [CrossRef]

430. Ita, F.; Mayer, E.F.; Verdonck, K.; Gonzalez, E.; Clark, D.; Gotuzzo, E. Human T-lymphotropic virus type 1 infection is frequent in rural communities of the southern Andes of Peru. Int. J. Infect. Dis. 2014, 19, 46-52. [CrossRef]

431. Zurita, S.; Costa, C.; Watts, D.; Indacochea, S.; Campos, P.; Sanchez, J.; Gotuzzo, E. Prevalence of human retroviral infection in Quillabamba and Cuzco, Peru: A new endemic area for human T cell lymphotropic virus type 1. Am. J. Trop. Med. Hyg. 1997, 56, 561-565. [CrossRef]

432. Alva, I.E.; Orellana, E.R.; Blas, M.M.; Bernabe-Ortiz, A.; Cotrina, A.; Chiappe, M.; Kochel, T.J.; Carcamo, C.P.; Garcia, P.J.; Zunt, J.R.; et al. HTLV-1 and -2 infections among 10 indigenous groups in the Peruvian Amazon. Am. J. Trop. Med. Hyg. 2012, 87, 954-956. [CrossRef]

433. Blas, M.M.; Alva, I.E.; Garcia, P.J.; Carcamo, C.; Montano, S.M.; Mori, N.; Munante, R.; Zunt, J.R. High prevalence of human T-lymphotropic virus infection in indigenous women from the peruvian Amazon. PLoS ONE 2013, 8, e73978. [CrossRef] 
434. Cartier, L.; Araya, F.; Castillo, J.L.; Zaninovic, V.; Hayami, M.; Miura, T.; Imai, J.; Sonoda, S.; Shiraki, H.; Miyamoto, K.; et al. Southernmost carriers of HTLV-I/II in the world. Jpn. J. Cancer Res. 1993, 84, 1-3. [CrossRef]

435. Cartier, L.; Tajima, K.; Araya, F.; Castillo, J.L.; Zaninovic, V.; Hayami, M.; Imai, J.; Born, P.; Cardenas, M.; Moreno, J.; et al. Preliminary study of HTLV-I seroprevalence in Chilean Indian populations. Rev. Med. Chile 1993, 121, 241-246.

436. Inostroza, J.; Diaz, P.; Saunier, C. Prevalence of antibodies to HTLV-1 in South American Indians (Mapuches) from Chile. Scand. J. Infect. Dis. 1991, 23, 507-508. [CrossRef] [PubMed]

437. Fujiyoshi, T.; Li, H.C.; Lou, H.; Yashiki, S.; Karino, S.; Zaninovic, V.; Oneegllo, S.G.; Camacho, M.; Andrade, R.; Hurtado, L.V.; et al. Characteristic distribution of HTLV type I and HTLV type II carriers among native ethnic groups in South America. AIDS Res. Hum. Retrovir. 1999, 15, 1235-1239. [CrossRef] [PubMed]

438. Maloney, E.M.; Biggar, R.J.; Neel, J.V.; Taylor, M.E.; Hahn, B.H.; Shaw, G.M.; Blattner, W.A. Endemic human T cell lymphotropic virus type II infection among isolated Brazilian Amerindians. J. Infect. Dis. 1992, 166, 100-107. [CrossRef] [PubMed]

439. Menna-Barreto, M.; Bender, A.L.; Bonatto, S.L.; Freitas, L.B.; Salzano, F.M.; Tsuneto, L.T.; Petzl-Erler, M.L. Human T-cell lymphotropic virus type II in Guarani Indians, Southern Brazil. Cad. Saúde Pública 2005, 21, 1947-1951. [CrossRef]

440. Biglione, M.; Vidan, O.; Mahieux, R.; de Colombo, M.; de los Angeles de Basualdo, M.; Bonnet, M.; Pankow, G.; De Efron, M.A.; Zorrilla, A.; Tekaia, F.; et al. Seroepidemiological and molecular studies of human T cell lymphotropic virus type II, subtype b, in isolated groups of Mataco and Toba Indians of northern Argentina. AIDS Res. Hum. Retrovir. 1999, 15, 407-417. [CrossRef]

441. Bouzas, M.B.; Zapiola, I.; Quiruelas, S.; Gorvein, D.; Panzita, A.; Rey, J.; Carnese, F.P.; Corral, R.; Perez, C.; Zala, C.; et al. HTLV type I and HTLV type II infection among Indians and natives from Argentina. AIDS Res. Hum. Retrovir. 1994, 10, 1567-1571. [CrossRef]

442. Ferrer, J.F.; Esteban, E.; Dube, S.; Basombrio, M.A.; Segovia, A.; Peralta-Ramos, M.; Dube, D.K.; Sayre, K.; Aguayo, N.; Hengst, J.; et al. Endemic infection with human T cell leukemia/lymphoma virus type IIB in Argentinean and Paraguayan Indians: Epidemiology and molecular characterization. J. Infect. Dis. 1996, 174, 944-953. [CrossRef]

443. Medeot, S.; Nates, S.; Recalde, A.; Gallego, S.; Maturano, E.; Giordano, M.; Serra, H.; Reategui, J.; Cabezas, C. Prevalence of antibody to human $\mathrm{T}$ cell lymphotropic virus types $1 / 2$ among aboriginal groups inhabiting northern Argentina and the Amazon region of Peru. Am. J. Trop. Med. Hyg. 1999, 60, 623-629. [CrossRef]

444. Echeverria de Perez, G.; Leon-Ponte, M.; Noya, O.; Botto, C.; Gallo, D.; Bianco, N. First description of endemic HTLV-II infection among Venezuelan Amerindians. J. Acquir. Immune Defic. Syndr. 1993, 6, 1368-1372.

445. Leon-Ponte, M.; Echeverria de Perez, G.; Bianco, N.; Hengst, J.; Dube, S.; Love, J.; Poiesz, B.J. Endemic infection with HTLV-IIB in Venezuelan Indians: Molecular characterization. J. Acquir. Immune Defic. Syndr. Hum. Retrovirol. 1998, 17, 458-464. [CrossRef]

446. Leon-Ponte, M.; Noya, O.; Bianco, N.; Echeverria de Perez, G. Highly endemic human T-lymphotropic virus type II (HTLV-II) infection in a Venezuelan Guahibo Amerindian group. J. Acquir. Immune Defic. Syndr. Hum. Retrovirol. 1996, 13, 281-286. [CrossRef] [PubMed]

447. Dangond, F.; Daza, J.S.; Rosania, A.; Quin, M.J.; Zaninovic, V.; Chaplin, B.; Marlink, R.; Hafler, D.A. Tropical spastic paraparesis on the Caribbean coast of Colombia. Am. J. Trop. Med. Hyg. 1995, 52, 155-158. [CrossRef] [PubMed]

448. Rodgers-Johnson, P.; Gajdusek, D.C.; Morgan, O.S.; Zaninovic, V.; Sarin, P.S.; Graham, D.S. HTLV-I and HTLV-III antibodies and tropical spastic paraparesis. Lancet 1985, 2, 1247-1248. [CrossRef]

449. Roman, G.C.; Roman, L.N. Tropical spastic paraparesis. A clinical study of 50 patients from Tumaco (Colombia) and review of the worldwide features of the syndrome. J. Neurol. Sci. 1988, 87, 121-138. [PubMed]

450. Vernant, J.C.; Maurs, L.; Gessain, A.; Barin, F.; Gout, O.; Delaporte, J.M.; Sanhadji, K.; Buisson, G.; de-The, G. Endemic tropical spastic paraparesis associated with human T-lymphotropic virus type I: A clinical and seroepidemiological study of 25 cases. Ann. Neurol. 1987, 21, 123-130. [CrossRef]

451. Zaninovic, V.; Leon, S.F. Fifteen years of follow-up on HTLV-I positive and HTLV-I negative spastic paraparesis patients in southwestern Colombia, South America. J. Neurovirol. 1996, 2, 357-360. [CrossRef]

452. Gotuzzo, E.; Cabrera, J.; Deza, L.; Verdonck, K.; Vandamme, A.M.; Cairampoma, R.; Vizcarra, D.; Cabada, M.; Narvarte, G.; De las Casas, C. Clinical characteristics of patients in Peru with human T cell lymphotropic virus type 1-associated tropical spastic paraparesis. Clin. Infect. Dis. 2004, 39, 939-944. [CrossRef] 
453. Gotuzzo, E.; De Las Casas, C.; Deza, L.; Cabrera, J.; Castaneda, C.; Watts, D. Tropical spastic paraparesis and HTLV-I infection: Clinical and epidemiological study in Lima, Peru. J. Neurol. Sci. 1996, 143, 114-117. [CrossRef]

454. Gotuzzo, E.; Moody, J.; Verdonck, K.; Cabada, M.M.; Gonzalez, E.; Van Dooren, S.; Vandamme, A.M.; Terashima, A.; Vermund, S.H. Frequent HTLV-1 infection in the offspring of Peruvian women with HTLV-1-associated myelopathy/tropical spastic paraparesis or strongyloidiasis. Panam. Salud Pública 2007, 22, 223-230. [CrossRef]

455. Talledo, M.; Lopez, G.; Huyghe, J.R.; Verdonck, K.; Adaui, V.; Gonzalez, E.; Best, I.; Clark, D.; Vanham, G.; Gotuzzo, E.; et al. Evaluation of host genetic and viral factors as surrogate markers for HTLV-1-associated myelopathy/tropical spastic paraparesis in Peruvian HTLV-1-infected patients. J. Med. Virol. 2010, 82, 460-466. [CrossRef]

456. Torres-Cabala, C.A.; Curry, J.L.; Li Ning Tapia, E.M.; Ramos, C.; Tetzlaff, M.T.; Prieto, V.G.; Miranda, R.N.; Bravo, F. HTLV-1-associated infective dermatitis demonstrates low frequency of FOXP3-positive T-regulatory lymphocytes. J. Dermatol. Sci. 2015, 77, 150-155. [CrossRef] [PubMed]

457. Kendall, E.A.; Gonzalez, E.; Espinoza, I.; Tipismana, M.; Verdonck, K.; Clark, D.; Vermund, S.H.; Gotuzzo, E. Early neurologic abnormalities associated with human T-cell lymphotropic virus type 1 infection in a cohort of Peruvian children. J. Pediatr. 2009, 155, 700-706. [CrossRef] [PubMed]

458. Barros, N.; Risco, J.; Rodriguez, C.; Sanchez, C.; Gonzalez, E.; Tanaka, Y.; Gotuzzo, E.; White, A.C.; Montes, M. $\mathrm{CD}^{+} \mathrm{T}$ cell subsets and Tax expression in HTLV-1 associated diseases. Pathog. Glob. Health 2013, 107, $202-206$. [CrossRef] [PubMed]

459. Malpica, L.; White, A.C., Jr.; Leguia, C.; Freundt, N.; Barros, N.; Chian, C.; Antunez, E.A.; Montes, M. Regulatory $\mathrm{T}$ cells and IgE expression in duodenal mucosa of Strongyloides stercoralis and human $\mathrm{T}$ lymphotropic virus type 1 co-infected patients. PLoS Negl. Trop. Dis. 2019, 13, e0007415. [CrossRef]

460. Cartier, L.; Ramirez, E. Presence of HTLV-I Tax protein in cerebrospinal fluid from HAM/TSP patients. Arch. Virol. 2005, 150, 743-753. [CrossRef] [PubMed]

461. Cartier-Rovirosa, L.; Mora, C.; Araya, F.; Castillo, J.; Verdugo, R.; Miller, M.A.; Gajdusek, D.C.; Gibbs, C.J., Jr. HTLV-I positive spastic paraparesis in a temperate zone. Lancet 1989, 1, 556-557. [CrossRef]

462. Ramirez, E.; Cartier, L.; Rodriguez, L.; Alberti, C.; Valenzuela, M.A. In vivo fluctuation of Tax, Foxp3, CTLA-4, and GITR mRNA expression in $\mathrm{CD} 4\left({ }^{+}\right) \mathrm{CD} 25\left(^{+}\right) \mathrm{T}$ cells of patients with human T-lymphotropic virus type 1-associated myelopathy. Braz. J. Med. Biol. Res. 2010, 43, 1109-1115. [CrossRef]

463. Ramirez, E.; Fernandez, J.; Cartier, L.; Villota, C.; Rios, M. Defective human T-cell lymphotropic virus type I (HTLV-I) provirus in seronegative tropical spastic paraparesis/HTLV-I-associated myelopathy (TSP/HAM) patients. Virus Res. 2003, 91, 231-239. [CrossRef]

464. Biglione, M.M.; Pizarro, M.; Puca, A.; Salomon, H.E.; Berria, M.I. A cluster of human T-cell lymphotropic virus type I-associated myelopathy/tropical spastic paraparesis in Jujuy, Argentina. J. Acquir. Immune Defic. Syndr. 2003, 32, 441-445. [CrossRef]

465. Biglione, M.M.; Pizarro, M.; Salomon, H.E.; Berria, M.I. A possible case of myelopathy/tropical spastic paraparesis in an Argentinian woman with human T lymphocyte virus type II. Clin. Infect. Dis. 2003, 37, 456-458. [CrossRef]

466. Gonzalez, L.A.; Villa, A.M.; Kohler, G.; Garcea, O.; Kremenchutzky, M.; Caceres, F.; Sanz, O.P.; Sica, R.E. Further studies on HTLV-I associated myelopathy in Argentina. Medicina 1998, 58, 411-414. [PubMed]

467. Lupo, S.; Berini, C.; Canepa, C.; Santini Araujo, E.; Biglione, M. Undifferentiated Pleomorphic Sarcoma and the Importance of Considering the Oncogenic and Immune-Suppressant Role of the Human T-Cell Lymphotropic Virus Type 1: A Case Report. Front. Oncol. 2017, 7, e00091. [CrossRef] [PubMed]

468. Zala, C.; Zapiola, I.; Bouzas, M.B.; Benetucci, J.; Lopez, L.; Gallo, D.; Hanson, C.; Muchinik, G.R. Human T-cell lymphotropic virus type I disease in Argentine intravenous drug users with human immunodeficiency virus type 1 infection. J. Acquir. Immune Defic. Syndr. 1994, 7, 870-871.

469. Fukutani, E.R.; Ramos, P.I.P.; Kasprzykowski, J.I.; Azevedo, L.G.; Rodrigues, M.M.S.; Lima, J.; de Araujo Junior, H.F.S.; Fukutani, K.F.; de Queiroz, A.T.L. Meta-Analysis of HTLV-1-Infected Patients Identifies CD40LG and GBP2 as Markers of ATLL and HAM/TSP Clinical Status: Two Genes Beat as One. Front. Genet. 2019, 10, 1056. [CrossRef] [PubMed]

470. Gomes, I.; Melo, A.; Proietti, F.A.; Moreno-Carvalho, O.; Loures, L.A.; Dazza, M.C.; Said, G.; Larouze, B.; Galvao-Castro, B. Human T lymphotropic virus type I (HTLV-I) infection in neurological patients in Salvador, Bahia, Brazil. J. Neurol. Sci. 1999, 165, 84-89. [CrossRef]

471. Oliveira, P.D.; de Carvalho, R.F.; Bittencourt, A.L. Adult T-cell leukemia/lymphoma in South and Central America and the Caribbean: Systematic search and review. Int. J. STD AIDS 2017, 28, 217-228. [CrossRef] 
472. Oliveira, P.D.; Kachimarek, A.C.; Bittencourt, A.L. Early Onset of HTLV-1 Associated Myelopathy/Tropical Spastic Paraparesis (HAM/TSP) and Adult T-cell Leukemia/Lymphoma (ATL): Systematic Search and Review. J. Trop. Pediatr. 2018, 64, 151-161. [CrossRef]

473. Casseb, J.; de Oliveira, A.C.; Vergara, M.P.; Montanheiro, P.; Bonasser, F.; Meilman Ferreira, C.; Smid, J.; Duarte, A.J. Presence of tropical spastic paraparesis/human T-cell lymphotropic virus type 1-associated myelopathy (TSP/HAM)-like among HIV-1-infected patients. J. Med. Virol. 2008, 80, 392-398. [CrossRef]

474. Harrison, L.H.; Vaz, B.; Taveira, D.M.; Quinn, T.C.; Gibbs, C.J.; de Souza, S.H.; McArthur, J.C.; Schechter, M. Myelopathy among Brazilians coinfected with human T-cell lymphotropic virus type I and HIV. Neurology 1997, 48, 13-18. [CrossRef]

475. De Oliveira Mde, F.; Fatal, P.L.; Primo, J.R.; da Silva, J.L.; Batista Eda, S.; Farré, L.; Bittencourt, A.L. Infective dermatitis associated with human T-cell lymphotropic virus type 1: Evaluation of 42 cases observed in Bahia, Brazil. Clin. Infect. Dis. 2012, 54, 1714-1719. [CrossRef]

476. Bonamigo, R.R.; Borges, K.; Rietjens, J.; Arenzon, S.; Blanco, L.F.; Loureiro, R. Human T lymphotropic virus 1 and hepatitis $\mathrm{C}$ virus as risk factors for inflammatory dermatoses in HIV-positive patients. Int. J. Dermatol. 2004, 43, 568-570. [CrossRef] [PubMed]

477. Dantas, L.; Netto, E.; Glesby, M.J.; Carvalho, E.M.; Machado, P. Dermatological manifestations of individuals infected with human T cell lymphotropic virus type I (HTLV-I). Int. J. Dermatol. 2014, 53, 1098-1102. [CrossRef] [PubMed]

478. Nobre, V.; Guedes, A.C.; Proietti, F.A.; Martins, M.L.; Nassif, G.; Serufo, J.C.; Lambertucci, J.R. Increased prevalence of human $\mathrm{T}$ cell lymphotropic virus type 1 in patients attending a Brazilian dermatology clinic. Intervirology 2007, 50, 316-318. [CrossRef] [PubMed]

479. Okajima, R.; Casseb, J.; Sanches, J.A. Co-presentation of human T-cell lymphotropic virus type 1 (HTLV-1)-associated myelopathy/tropical spastic paraparesis and adult-onset infective dermatitis associated with HTLV-1 infection. Int. J. Dermatol. 2013, 52, 63-68. [CrossRef]

480. Okajima, R.; Oliveira, A.C.; Smid, J.; Casseb, J.; Sanches, J.A., Jr. High prevalence of skin disorders among HTLV-1 infected individuals independent of clinical status. PLoS Negl. Trop. Dis. 2013, 7, e2546. [CrossRef]

481. Martins, F.M.; Casseb, J.; Penalva-de-Oliveira, A.C.; de Paiva, M.F.; Watanuki, F.; Ortega, K.L. Oral manifestations of human T-cell lymphotropic virus infection in adult patients from Brazil. Oral Dis. 2010, 16, 167-171. [CrossRef]

482. Rathsam-Pinheiro, R.H.; Boa-Sorte, N.; Castro-Lima-Vargens, C.; Pinheiro, C.A.; Castro-Lima, H.; Galvao-Castro, B. Ocular lesions in HTLV-1 infected patients from Salvador, State of Bahia: The city with the highest prevalence of this infection in Brazil. Rev. Soc. Bras. Med. Trop. 2009, 42, 633-637. [CrossRef]

483. Leite, A.C.; Silva, M.T.; Alamy, A.H.; Afonso, C.R.; Lima, M.A.; Andrada-Serpa, M.J.; Nascimento, O.J.; Araujo, A.Q. Peripheral neuropathy in HTLV-I infected individuals without tropical spastic paraparesis/HTLV-I-associated myelopathy. J. Neurol. 2004, 251, 877-881. [CrossRef]

484. Chavez, M.; Domiguez, M.C.; Blank, A.; Quintana, M.; Eizuru, Y.; Garcia, F. Molecular evolution and geographic origins of type 1 human lymphotrophic virus in Colombia detected by RFLP polymorphism. Biomedica 2004, 24, 20-32.

485. Magri, M.C.; Brigido, L.F.; Rodrigues, R.; Morimoto, H.K.; Ferreira, J.L.; Caterino-de-Araujo, A. Phylogenetic and similarity analysis of HTLV-1 isolates from HIV-coinfected patients from the south and southeast regions of Brazil. AIDS Res. Hum. Retrovir. 2012, 28, 110-114. [CrossRef]

486. Miura, T.; Yamashita, M.; Zaninovic, V.; Cartier, L.; Takehisa, J.; Igarashi, T.; Ido, E.; Fujiyoshi, T.; Sonoda, S.; Tajima, K.; et al. Molecular phylogeny of human T-cell leukemia virus type I and II of Amerindians in Colombia and Chile. J. Mol. Evol. 1997, 44, S76-S82. [CrossRef] [PubMed]

487. Nobre, A.F.S.; Almeida, D.S.; Ferreira, L.C.; Ferreira, D.L.; Junior, E.C.S.; Viana, M.; Silva, I.C.; Pinheiro, B.T.; Ferrari, S.F.; Linhares, A.D.C.; et al. Low genetic diversity of the Human T-cell Lymphotropic Virus (HTLV-1) in an endemic area of the Brazilian Amazon basin. PLoS ONE 2018, 13, e0194184. [CrossRef]

488. Love, J.L.; Marchioli, C.C.; Dube, S.; Bryz-Gornia, V.; Loughran, T.P., Jr.; Glaser, J.B.; Esteban, E.; Feldman, L.; Ferrer, J.F.; Poiesz, B.J. Expansion of clonotypic T-cell populations in the peripheral blood of asymptomatic Gran Chaco Amerindians infected with HTLV-IIB. J. Acquir. Immune Defic. Syndr. Hum. Retrovirol. 1998, 18, 178-185. [CrossRef]

489. Santos, E.L.; Tamegao-Lopes, B.; Machado, L.F.; Ishak Mde, O.; Ishak, R.; Lemos, J.A.; Vallinoto, A.C. Molecular characterization of HTLV-1/2 among blood donors in Belem, State of Para: First description of HTLV-2b subtype in the Amazon region. Rev. Soc. Bras. Med. Trop. 2009, 42, 271-276. [CrossRef] [PubMed] 
490. Pardi, D.; Switzer, W.M.; Hadlock, K.G.; Kaplan, J.E.; Lal, R.B.; Folks, T.M. Complete nucleotide sequence of an Amerindian human T-cell lymphotropic virus type II (HTLV-II) isolate: Identification of a variant HTLV-II subtype b from a Guaymi Indian. J. Virol. 1993, 67, 4659-4664. [CrossRef] [PubMed]

491. Magri, M.C.; Brigido, L.F.; Morimoto, H.K.; Caterino-de-Araujo, A. Human T cell lymphotropic virus type 2a strains among HIV type 1-coinfected patients from Brazil have originated mostly from Brazilian Amerindians. AIDS Res. Hum. Retrovir. 2013, 29, 1010-1018. [CrossRef] [PubMed]

492. Vallinoto, A.C.; Ishak, M.O.; Azevedo, V.N.; Vicente, A.C.; Otsuki, K.; Hall, W.W.; Ishak, R. Molecular epidemiology of human T-lymphotropic virus type II infection in Amerindian and urban populations of the Amazon region of Brazil. Hum. Biol. 2002, 74, 633-644. [CrossRef]

493. Switzer, W.M.; Black, F.L.; Pieniazek, D.; Biggar, R.J.; Lal, R.B.; Heneine, W. Endemicity and phylogeny of the human T cell lymphotropic virus type II subtype A from the Kayapo Indians of Brazil: Evidence for limited regional dissemination. AIDS Res. Hum. Retrovir. 1996, 12, 635-640. [CrossRef]

494. Grande, B.M.; Gerhard, D.S.; Jiang, A.; Griner, N.B.; Abramson, J.S.; Alexander, T.B.; Allen, H.; Ayers, L.W.; Bethony, J.M.; Bhatia, K.; et al. Genome-wide discovery of somatic coding and noncoding mutations in pediatric endemic and sporadic Burkitt lymphoma. Blood 2019, 133, 1313-1324. [CrossRef]

495. Montes-Mojarro, I.A.; Kim, W.Y.; Fend, F.; Quintanilla-Martinez, L. Epstein-Barr virus positive T and NK-cell lymphoproliferations: Morphological features and differential diagnosis. Semin. Diagn. Pathol. 2020, 37, 32-46. [CrossRef]

496. Ok, C.Y.; Li, L.; Xu-Monette, Z.Y.; Visco, C.; Tzankov, A.; Manyam, G.C.; Montes-Moreno, S.; Dybkaer, K.; Chiu, A.; Orazi, A.; et al. Prevalence and clinical implications of epstein-barr virus infection in de novo diffuse large B-cell lymphoma in Western countries. Clin. Cancer Res. 2014, 20, 2338-2349. [CrossRef] [PubMed]

497. Cohen, J.I.; Iwatsuki, K.; Ko, Y.H.; Kimura, H.; Manoli, I.; Ohshima, K.; Pittaluga, S.; Quintanilla-Martinez, L.; Jaffe, E.S. Epstein-Barr virus NK and T cell lymphoproliferative disease: Report of a 2018 international meeting. Leuk. Lymphoma 2020, 61, 808-819. [CrossRef] [PubMed]

498. Koo, G.C.; Tan, S.Y.; Tang, T.; Poon, S.L.; Allen, G.E.; Tan, L.; Chong, S.C.; Ong, W.S.; Tay, K.; Tao, M.; et al. Janus kinase 3-activating mutations identified in natural killer/T-cell lymphoma. Cancer Discov. 2012, 2, 591-597. [CrossRef] [PubMed]

499. Küçük, C.; Jiang, B.; Hu, X.; Zhang, W.; Chan, J.K.; Xiao, W.; Lack, N.; Alkan, C.; Williams, J.C.; Avery, K.N.; et al. Activating mutations of STAT5B and STAT3 in lymphomas derived from $\gamma \delta$-T or NK cells. Nat. Commun. 2015, 6, 6025. [CrossRef]

500. Montes-Mojarro, I.A.; Chen, B.J.; Ramirez-Ibarguen, A.F.; Quezada-Fiallos, C.M.; Perez-Baez, W.B.; Duenas, D.; Casavilca-Zambrano, S.; Ortiz-Mayor, M.; Rojas-Bilbao, E.; Garcia-Rivello, H.; et al. Mutational profile and EBV strains of extranodal NK/T-cell lymphoma, nasal type in Latin America. Mod. Pathol. 2020, 33, 781-791. [CrossRef]

501. Garcia, A.; Olivella, F.; Valderrama, S.; Rodriguez, G. Kaposi's sarcoma in Colombia. Cancer 1989, 64, $2393-2398$. [CrossRef]

502. Kourí, V.; Martínez, P.A.; Blanco, O.; Capó, V.; Rodríguez, M.E.; Dovigny, M.D.C.; Cardellá, L.; Gala, A.; Jiménez, N.A.; Correa, C.; et al. Simultaneous quantification of human herpesvirus 8 DNA by real time PCR in different tissues of HIV infected cuban patients with Kaposi's sarcoma. Herpesviridae 2010, 1, 3. [CrossRef]

503. Maita Zegarra, R.B.; Meléndez Guevara, R.A.; Seminario de Rivera, V. Factor VIII en sarcoma de Kaposi y verruga peruana. Galeno 1985, 15, 14-17.

504. CA, C. Tumores Cutáneos en el Hospital Cayetano Heredia Entre Los Años. Tesis para Optar el Título de Médico Cirujano 1992-1995. Ph.D. Thesis, Universidad Peruana Cayetano, San Martin, Peru.

505. Borges, J.D.; Souza, V.A.; Giambartolomei, C.; Dudbridge, F.; Freire, W.S.; Gregorio, S.A.; Torrez, P.P.; Quiroga, M.; Mayaud, P.; Pannuti, C.S.; et al. Transmission of human herpesvirus type 8 infection within families in american indigenous populations from the Brazilian Amazon. J. Infect. Dis. 2012, 205, 1869-1876. [CrossRef]

506. Centers for Disease Control. Human T-lymphotropic virus type II among Guaymi Indians-Panama. MMWR. Morb. Mortal. Wkly. Rep. 1992, 41, 209-211.

507. Gonzalez-Perez, M.P.; Munoz-Juarez, L.; Cardenas, F.C.; Zarranz Imirizaldu, J.J.; Carranceja, J.C.; Garcia-Saiz, A. Human T-cell leukemia virus type I infection in various recipients of transplants from the same donor. Transplantation 2003, 75, 1006-1011. [CrossRef] [PubMed]

508. Zaninovic, V.; Biojó, R.; Barreto, P. Paraparesia espástica del Pacífico. Colombia Med. 1981, 12, $111-117$. 
509. Zabaleta, M.; Peralta, J.; Birges, J.; Bianco, N.; Echeverria de Perez, G. HTLV-I-associated myelopathy in Venezuela. J. Acquir. Immune Defic. Syndr. 1994, 7, 1289-1290. [CrossRef] [PubMed]

510. Iwanaga, M.; Watanabe, T.; Yamaguchi, K. Adult T-cell leukemia: A review of epidemiological evidence. Front. Microbiol. 2012, 3, e00322. [CrossRef]

(c) (C) 2020 by the authors. Licensee MDPI, Basel, Switzerland. This article is an open access article distributed under the terms and conditions of the Creative Commons Attribution (CC BY) license (http://creativecommons.org/licenses/by/4.0/). 